\title{
Middle-Late Jurassic plant assemblages of the Catlins coast, New Zealand
}

\author{
Mike Pole
}

\begin{abstract}
Jurassic plant macrofossils from along New Zealand's far-south 'Catlins Coast' (between Fortrose and the mouth of the Catlins River) are described. New records and the consequences of other taxonomic changes means there are additions to the list of plant taxa in the New Zealand Jurassic.

Hausmannia, Archangelskya, Pseudoctenis, and Bellarinea are recorded for the first time in New Zealand. The taxonomic changes include synonymising Equisetum nicoli with E. laterale, transferring Pterostoma matauraensis to Pseudoctenis? ensiformis, and Ptilophyllum acutifolium to Otozamites douglasii. The material commonly ascribed to Cladophlebis australis remains problematic, but is here regarded as $C$. patagonica, although other species may exist.

There is little clear indication of floristic assemblages restricted to particular facies. Very low diversity assemblages with Cladophlebis and/or Taeniopteris are almost ubiquitous, and probably represent a very generalised pioneering vegetation. Conifers may have been added as a component of a later stage of succession. A notably distinct assemblage, dominated by very narrow leaved Taeniopteris and Bellarinea, occurs in the axis of the Waikawa Syncline. It may be the youngest assemblage in the region and could be of zonal significance.

Due to its location on an independent terrane, the exact location of the Catlins area during the Jurassic is unclear, although it was somewhere along the edge of Gondwana and possibly not far from what is now Queensland. The low diversity and relatively small leaves of the assemblages is consistent with a relatively high-latitude setting. Current knowledge probably cannot confirm the palaeolatitude more precisely than somewhere below the Polar Circle, to significantly above it.
\end{abstract}

Mike Pole. Queensland Herbarium, Brisbane Botanic Gardens Mt Coot-tha, Toowong, Qld, Australia. murihiku@yahoo.com

Keywords: Murihiku; Jurassic; Catlins; macrofossils

Submission: 21 October 2019. Acceptance: 23 October 2020.

Pole, Mike. 2020. Middle-Late Jurassic plant assemblages of the Catlins coast, New Zealand. Palaeontologia Electronica, 23(3):a51. https://doi.org/10.26879/1039

palaeo-electronica.org/content/2020/3193-catlins-coast-jurassic

Copyright: November 2020 Paleontological Society.

This is an open access article distributed under the terms of Attribution-NonCommercial-ShareAlike 4.0 International (CC BY-NC-SA 4.0), which permits users to copy and redistribute the material in any medium or format, provided it is not used for commercial purposes and the original author and source are credited, with indications if any changes are made.

creativecommons.org/licenses/by-nc-sa/4.0/ 


\section{INTRODUCTION}

The 'Catlins coast' lies in the southeastern corner of the South Island of New Zealand and roughly describes the area between the Catlins River and Fortrose (Figure 1). It is relatively remote and still poorly known geologically. However, it includes Curio Bay, a well-known tourist destination with in situ Jurassic fossil forests.

The macropalaeobotany of the area has been described in several papers, including the comprehensive works of Arber (1917) and Edwards (1934), and the classic silicified fern work of Kidston and Gwynne-Vaughan (1907, 1908, 1909, 1910). A significant addition described a new wood genus, Donponoxylon, with similarities to the wellknown Pentoxylon (Tidwell et al., 2013). The macroflora of New Zealand's Jurassic was reviewed by

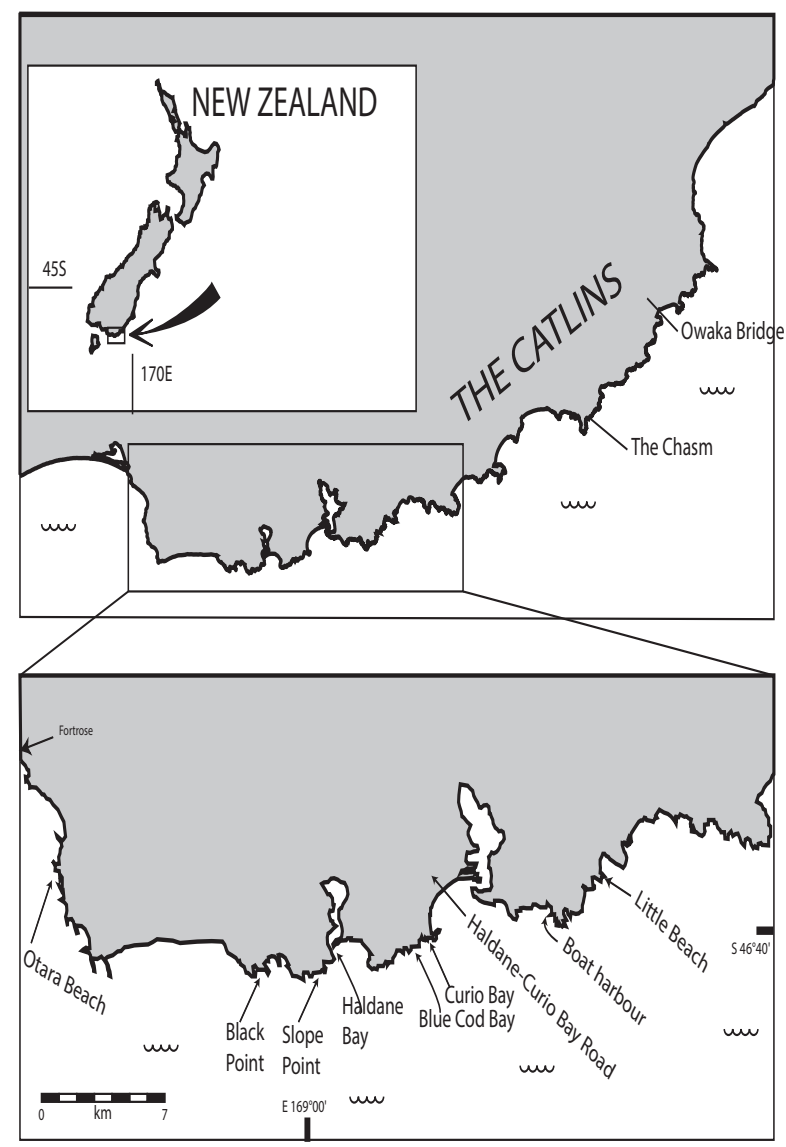

FIGURE 1. Catlins Coast fossil locality map. Arrow in the upper inset map points to a rectangle that delineates the general region along the southern coast of New Zealand's South Island. The upper map indicates the whole area regarded as 'Catlins Coast' in this work, and shows the Owaka and Chasm localities, which are a little distant from the others, and it delineates a rectangular area, which is shown in detail in the lower map.
Pole (2009; note also Johnston et al., 1987, and Raine, 1982, 1987, which were inadvertently omitted). Palynological studies covering the area include those of de Jersey and Raine (1990) and Thorn (2001).

The aim of this paper is to document new palaeobotanical material from the Catlins Coast. This is an opportunity to both reviewing the taxonomy of fossil plants from localities that have been long-known in the light of recent papers elsewhere, as well as introducing some new ones.

\section{GEOLOGICAL SETTINGS}

\section{Structure}

The Catlins Coast area was geologically mapped by Watters et al. (1968) on a scale of 1 : 250000 . Details of the northern region were documented by Speden (1971) and of the south by Noda et al. (2002) and Pole (2004). Most of the southern region was included in the Ferndale Group by Turnbull and Allibone (2003), as well as exposures of the underlying Diamond Peak Group, for instance from The Sisters north to Chaslands.

The regional basement forms part of the Murihiku Terrane/Supergroup (Campbell and Coombs, 1966; Campbell et al., 2003), which was either a fore-arc (Briggs et al., 2004) or back-arc basin (Coombs et al., 1996) and deposited somewhere distal to a volcanically active margin, represented in New Zealand by the Median Batholith (Mortimer et al., 1999) along the margin of Gondwana (Ballance and Campbell, 1993; Grant-Mackie et al., 2000). The Murihiku Terrane is now separated from the Median Batholith by the Permian Brook Street Terrane, and its original location along the Gondwana foreland is unknown. Adams (2010) and Adams et al. (2007) have suggested that in general, before they amalgamated, there was an anticlockwise movement of terranes in the New Zealand sector of the Pacific. Thus, the Murihiku Terrane is likely to have come from somewhere further north with respect to Australia.

\section{Age}

Dating on the south limb of the Southland Syncline is hampered by the paucity of marine beds, tectonic breaks in the succession, and broad-ranging macrofloral taxa. Regional mapping began with Wood (1956) who divided the Catlins Jurassic into the Diamond Peak Group, the Ferndale Group, and the Mataura Group. Speden (1958) dated the Owaka Creek plant beds as lower to middle Callovian "or somewhat younger" (essen- 
tially latest Temaikan, Middle Jurassic) based on underlying marine fossils. The regional map of Watters et al. (1968) indicated the strata at Curio Bay as Temaikan (Middle Jurassic). This age was refined to Bathonian-Callovian (late Temaikan, c. 167-157 Ma) using palynological data (J.L. McKellar, J.I. Raine, and N. de Jersey, pers. comm., 1997 in Pole, 2001). Campbell et al. (2003) gave redefinitions for all three groups, which included an Early Jurassic, marine origin for the Diamond Peak Group, an early Middle Jurassic, marine-marginal marine origin for the Ferndale Group (which included Curio Bay), and a late Middle Jurassic, broader marine-terrestrial origin of the Mataura Group. The distribution of these groups was subsequently indicated by regional mapping (Turnbull and Alibone, 2003).

Pole (2004) attempted to trace the strata of the Fortrose-Chaslands coast into the better-dated marine material to the north but found apparent major breaks in stratigraphic continuity. He divided the coast into two tectonic 'blocks', the Slope Point Block and the Brothers Block, which were tectonically separate from the south limb of the Southland Syncline. Pole (2004) interpreted the sedimentary rocks of the Fortrose-Otara coast to be stratigraphically continuous with those at Curio Bay, but to lie some $500 \mathrm{~m}$ lower in the succession.

Pole (2004) wrote "The Brothers Block is unlikely to be younger than the youngest strata of the Papatowai Subdivision (which would make it the youngest Jurassic in Southland) although not impossible." Based on Carter's (1979) interpretation of the Southland Jurassic as generally regressive, the presence of marine strata in the Brothers Block suggested that it was "more likely that the Brothers Block correlates with the older Papatowai Subdivision units" and was broadly Lower Jurassic. However, whole-rock dating of Hoiho Conglomerate clasts in the Brothers Block (Noda et al., 2004) found one to be $156 \pm 8 \mathrm{Ma}$ (Oxfordian, Heterian, earliest Late Jurassic). On this basis, the Brothers Block is indeed the youngest Jurassic in Southland, and this dating supports the existence of a tectonic break between it and the Slope Point Block (Pole, 2004), which includes Curio Bay. The strata along the Fortrose-Otara coast dip at a low angle (about $2-3^{\circ}$ ) to the northeast and strike approximately northwest-southeast, parallel to their exposure in coastal cliffs. They are distinct from those sedimentary rocks at Curio Bay, as they include extensive overbank fines, penetrating plants roots, coal, and well-sorted fluvial sands. They may correlate with the marine Pounawea
Formation further to the north on the South Limb of the Syncline. Further assessment of their age is pending.

\section{METHODS AND LOCALITIES}

This report is based on field work in the Catlins Coast region that has continued from the late 1970s until the present. It focuses on 10 broad localities (examples illustrated in Figure 2 and current understanding their stratigraphic relationships in Figure 3) in which plant macrofossils are present. Individual samples (i.e., separate beds or widely separated occurrences of beach boulders) are numbered with the general locality prefix. A GPS was used to locate the samples (accuracy c. $15 \mathrm{~m}$ ), and coordinates are given in New Zealand Transverse Mercator (NZTM). Specimens are numbered with the prefix 'LX' and deposited in the Geology Department, Auckland University. Unsuccessful attempts to isolate cuticle were made using hydrogen peroxide, chromium trioxide, and Schultze solution on the most likely specimens. However, the material is too metamorphosed and/or weathered for cuticle to survive, and therefore the study involved reflected light investigation of what are essentially impressions. The absence of cuticle and attached reproductive structures is a common problem for Mesozoic material, hampering confident placement into taxonomic levels, such as the family. The approach taken here is to place the taxa into their most-likely position in the Linnaean hierarchy, and then discussed, where appropriate, under the remarks. This is a pragmatic way of structuring the paper. It is not an assertion that any placement has been 'proved' and certainly not a claim that a particular form-genus can be assigned to a certain family.

\section{Otara Beach}

Plant fossils are common along approximately $2.5 \mathrm{~km}$ of coast adjacent to the community of Otara (from NZTM: 1280644, 4828974 to 1280736 , 4826569). The facies are relatively muddy and include very carbonaceous muds to thin coal beds and fossil soils (plant root horizons and at least eight in situ tree stump horizons) along with other fossil plant material. They are interpreted as mainly flood-basin fill, with mires, crevasse splay and avulsion deposits. A prominent light-coloured crystal tuff, composed of angular plagioclase crystals and containing large carbonised tree logs, provides a convenient marker-horizon at the northwest end. The facies are much more homogenous mud in the 

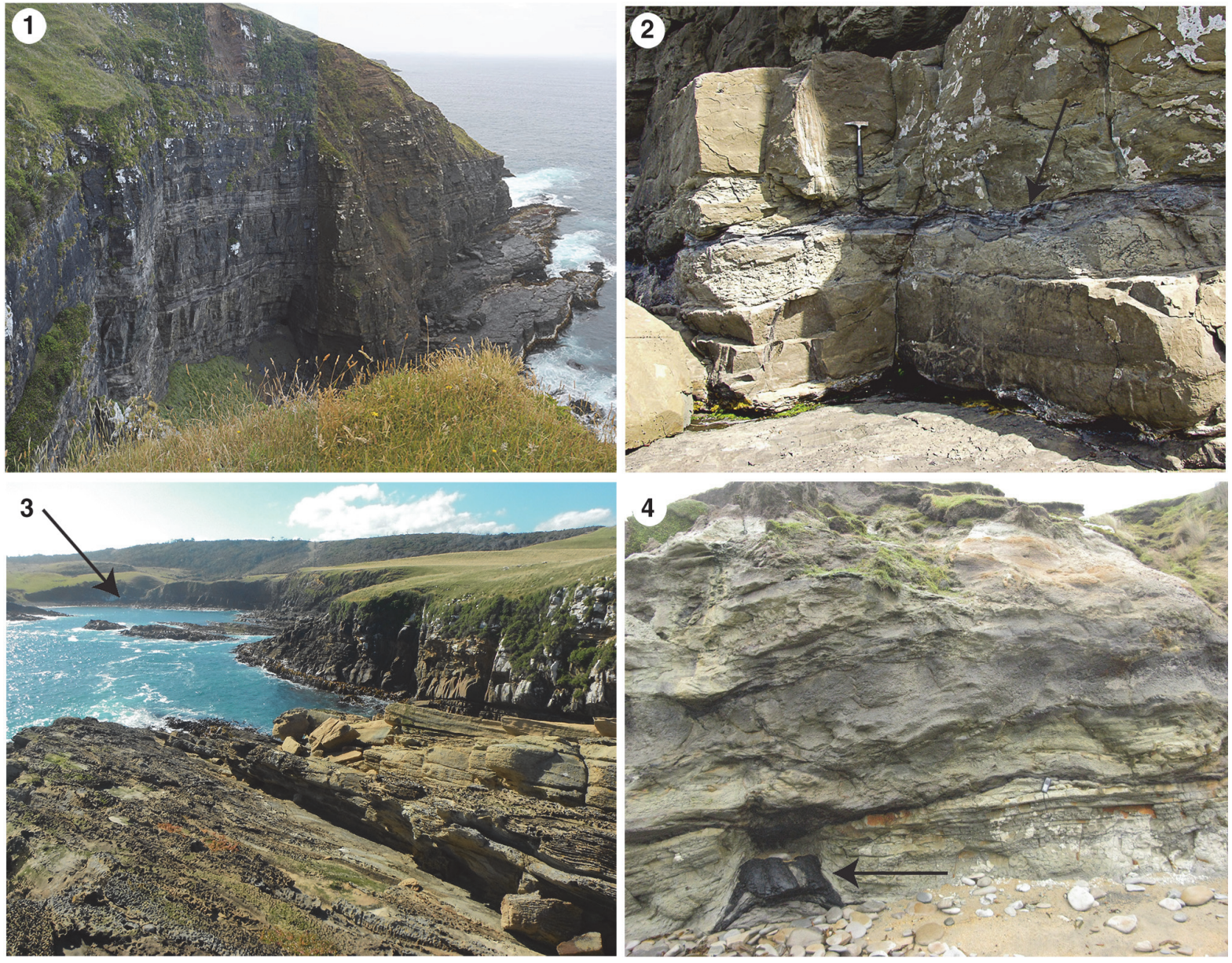

FIGURE 2. Representative Catlins Coast fossil locality photographs. 1. The Chasm. Fossils are from loose blocks at the base of the cliffs. 2. Little Beach. Note tree trunk to left of rock hammer, associated with soil (arrowed) 3. Boat Harbour. Approximate location of fossil site arrowed. 4. Otara Beach. Note tree stump (arrowed).

southeast. Samples from this region are prefixed with 'Otara-'. The relevant samples are:

- Otara-8 cliff exposure, greenish silt with roots, c. $30 \mathrm{~cm}$ below base of prominent channel sandstone and c. $30 \mathrm{~cm}$ above $20 \mathrm{~cm}$ thick unit of very carbonaceous mud-coal (NZTM: 1280544, 4828454)

- Otara-20, beach outcrop at high tide level (NZTM: 1280602, 4827577).

- Otara-21, fallen boulders at base of cliff (NZTM: 1280583, 4827644).

- Otara-31, base of cliff, grey mud underlying rusty stained mud (NZTM: 1280680, 4827000).

- Otara-32, base of cliff, grey mud underlying rusty stained mud, equivalent to Otara-31 (NZTM: 1280720, 4826960).
- Otara-33, base of cliff, c. $1.5 \mathrm{~m}$ above high water and under a small waterfall (NZTM: 1280530, 4827668).

- Otara-34, beach exposure between cliffs and reef (NZTM: 1280736, 4826569).

- Otara-35 base of cliff, c. $1.5 \mathrm{~m}$ above high water, immediately to left of small gully and waterfall (NZTM: 1280569, 4827680).

- Otara-36, c. 2 m of grey mud, minor faulting and folding, about $8 \mathrm{~m}$ stratigraphically above the crystal tuff.

\section{Black Point}

A fine-grained, plant rich bed was collected from the edge of the cove about one kilometre east of Black Point in the 1980s and 1990s (NZTM 1292380, 4823930). It includes the material described as Palissya by Parris et al. (1995). The horizon has not been located since and appears to have been covered by slumping. 


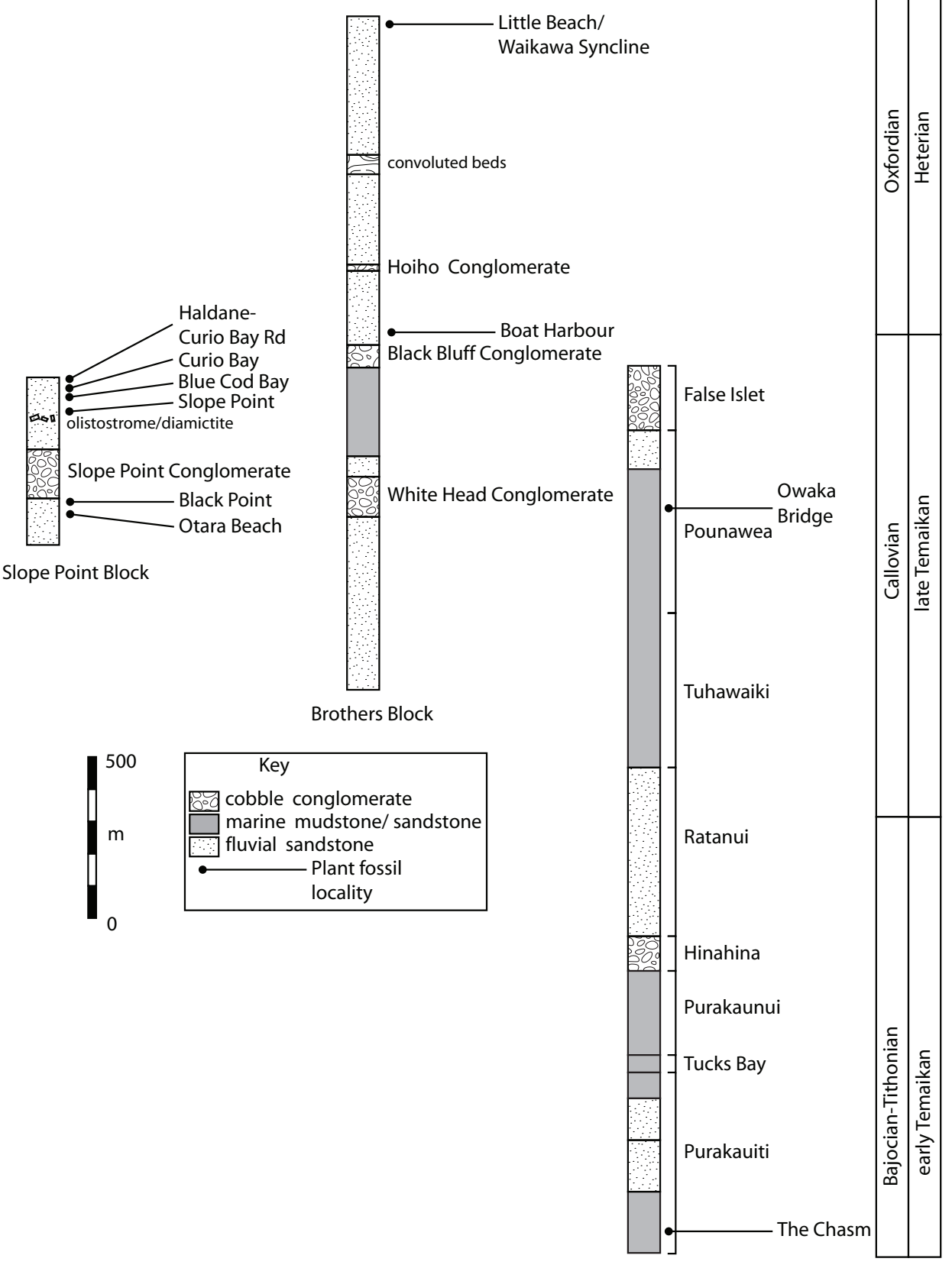

South limb of

Southland Syncline

FIGURE 3. Summary of the current understanding of stratigraphic relations of the fossil localities. These are simplified stratigraphic columns through the Slope Point Block and the Brothers Block (Pole, 2004) and the South Limb of the Southland Syncline (based on Speden, 1971). Pole (2004) proposed that all terrestrial sediments should be recognised as False Island Formation. For ease of comparison, the formations of Speden (1971) are indicated for the South Limb.

\section{Slope Point}

- Slope-01, fossil foliage and silicified wood is present in the boulders in the tidal zone along the western margin of the Haldane Bay (NZTM: 1296090, 4824550).
- Slope-02, very fine-grained beds (claystone) on the far eastern extent of the coastal cliffs extending east from Slope Point, almost to Haldane Bay, containing abundant Cladophlebis (NZTM: 1295955, 4824004). 
- Slope-03, loose blocks of sandstone at base of cliff (NZTM: 1294561, 4823533).

- Slope-04, boulders in rubble on platform at south end of bay (NZTM: 1295709, 4823749).

\section{Blue Cod Bay}

- Plant fossils are common in the boulders of Blue Cod Bay (NZTM: 1299957, 4824414).

\section{Curio Bay}

Curio Bay is a well-known locality (Arber, 1917; Edwards, 1934) containing in situ fossil forest horizons (NZTM: 1301560, 4824990). Older collections refer to it as 'Waikawa' (the name of a nearby village). The main forest horizon was composed of a relatively low canopy of conifers (Pole, 1999) with an understory of 'tree ferns' and nonconiferous gymnosperms. Multiple forest horizons appear to have been overwhelmed by a series of relatively unconfined fluvial flows (Pole, 2001). The dominant architecture is sheet-like. Broad channels are present, with a fill of poorly sorted very coarse-grained sandstone and grit, in some places as large (meter-scale) trough cross beds. A typical braided stream origin is not clear, based on the absence of planar tabular cross beds. A meandering stream origin is even less likely given the absence of lateral accretion and suspension sediment. However, there are relatively fine beds, some of lamina thickness, and they are associated with in situ fossil trees. These suggest an overbank/floodplain environment, but there is no evidence of clear channel/overbank distinction.

\section{Haldane-Curio Bay Road}

In 1982 a small road side exposure was collected on the Haldane-Curio Bay Road, about 400 $\mathrm{m}$ from the intersection with the Waikawa-Curio Bay Road (NZTM: 1301380, 4826200). It is very overgrown now. The material is highly weathered to a pale mud. Because of very limited exposure, little can be said of its sedimentology. The plant fossil assemblage is distinct in that it contains Pseudoctenis? ensiformis (previously PterophylIum matauraensis Hector, 1886), the first New Zealand record of this taxon outside of its type locality of Mataura.

\section{The Boat Harbour}

A Cladophlebis-dominated unit is present in the 'Boat Harbour' on the northwest side of Brothers Peninsula (NZTM: 1308699, 4826392). Noda et al. (2002, fig. 10A) illustrated Cladophlebis indica from here.

\section{Little Beach/Waikawa Syncline}

This broad locality covers a plant-fossil rich zone (c. $10 \mathrm{~m}$ thick) in the core of the Waikawa Syncline. Beach boulders with prominent narrowTaeniopteris and Bellarinea are present from the southernmost end of Little Beach and also in the unnamed bays south of the headland through which the axis of the Waikawa Syncline lies. Both regions are taken to expose the same unit, although continuous foot access around the intervening headlands is not possible.

- Little-01, boulders scattered along the southern end of Little Beach (NZTM: 1311943, 4827334).

- Little-02, prominent in situ silt unit under overhang on south side of cliff (NZTM: 1311522, 4827197).

- Little-03, beach boulders in the bay extending $100 \mathrm{~m}$ southwest from Little-02 (NZTM: 1311470, 4827167)

- Little-04, beach boulders in the bay immediately south of Little Beach (NZTM: 1311531, 4827304).

Noda et al. (2002) mapped this as part of their 'Lithofacies association D - meandering river and floodplain'. They wrote (p. 308) 'The dominance of planar cross-stratified and horizontally stratified sandstones is interpreted to indicate deposition under a lower energy flow regime.... A meandering river and flood plain are considered to be the possible sedimentary environment."

The present study finds no evidence for meandering stream origin - there is no sign of lateral accretion deposits characteristic of meandering channels or trough bedding. By themselves, planar cross-stratified beds are more indicative of braided deposition (Miall, 1977, 1978), and horizontally stratified sandstone is an indication of upper, rather than lower energy flow.

The sequence is sand-dominated (mud is essentially absent), with sharply defined boundaries between beds of different sand grades. Beds may be very thin (essentially lamina), with an internal architecture varying from planar cross-bedded, convoluted, to massive. Buried tree stumps in growth position within a carbonaceous sandy soil, may project through several distinct beds and indicate rapidly changing energy conditions. Minor bioturbation, lags of rip-up fine sandstone clasts. The geology is broadly comparable with the finergrained parts of Curio Bay (Pole, 2001). 


\section{Owaka}

A small outcrop with plant fossils occurring on farmland near the Owaka River (NZTM 1344900, 4851250) has been known since at least 1865 (collected by Hector as noted by Arber, 1917) and further described by McKay (1877) and Arber (1917). Mackie (1935) placed the beds in the upper part of his J14 unit, of 'Lower Oolite' age. Speden (1958) documented the local stratigraphy and found that the plant beds overlay marine beds of lower to middle Callovian age. He concluded they were of equivalent age (he surmised they represented a local shallowing in estuarine-terrestrial conditions), or "somewhat younger". He later (Speden, 1971) documented the more regional geology of the area and placed the plant beds at the top of his Pounawea Formation. Outcrop is now restricted and the material much weathered. The thin beds of sandstone and mudstone are probably flood-basin deposits.

\section{The Chasm}

Plant fossils are numerous in the boulders and shore platform near the feature known as The Chasm (NZTM: 1339054, 4837558). The locality was documented by Speden (1971, p. 72), who placed it in the Purakauiti Formation, about 530$595 \mathrm{~m}$ from the base. According to Speden (1971) the Purakauiti Formation is about 1190 m thick, lithologically heterogeneous, and includes many marine units as well as its characteristic carbonaceous beds. Marine invertebrates date the entire Purakauiti Formation as Temaikan, with Speden (1971) regarding it more specifically as "Lower Temaikan". He recorded marine invertebrates about $150 \mathrm{~m}$ stratigraphically above the Chasm Island plant beds. From the plant beds Speden listed; Cladophlebis australis, C. antarctica, C. cf. reversa, Taeniopteris, Dictyophyllum, Sphenopteris (Ruffordia) goepperti, Elatocladus conferta, ?Brachyphyllum, ?Nageiopsis, a ?conifer cone and some less identifiable fragments.

The section consists of sheet-like, sand-dominated units. Although access to the good exposure of the cliffs is very limited, and many of the beds are internally massive, examples of good bedding structures can be found as boulders on the shore. The mixture of trough cross-bedding, lag horizons of well-rounded cobbles, penetrating roots, and alternating thin beds, is consistent with a generally low-lying fluvial environment. Although clear marine strata lie above, there is no conclusive evidence of marine influence, such as tidal processes, at Chasm Island.

\section{SYSTEMATIC PALAEONTOLOGY}

Class POLYPODIOPSIDA sensu Ruggiero et al., 2015

Family OSMUNDACEAE Berchtold and Presl, 1820

Genus CLADOPHLEBIS Brongniart, 1849, emend. Seward, 1894

Remarks. Cladophlebis is probably the most ubiquitous plant fossil in the New Zealand Jurassic but despite this, nomenclature remains unclear. The first publication of plant fossils from New Zealand (Unger, 1864) describes Polypodium hochstetteri, material which would now be regarded as Cladophlebis. By the time of Arber (1917) and Edwards (1934) at least five species of Cladophlebis apparently, were known in the New Zealand Jurassic; Cladophlebis australis, C. sp. cf. C. albertsi, C. antarctica, C. denticulate, and C. cf. reversa. Arber (1917, p. 31) regarded C. australis as the "most abundant of all species, without exception" in the New Zealand Jurassic. Then, based on one of Arber's (1917, pl. 4 fig. 1) figures of Cladophlebis australis, Frenguelli (1947) erected a new species, Cladophlebis patagonica. In this taxon, the pinnules were distinctly elongate and well-separated from each other, and with lateral veins that mostly bifurcated a single time, except for one of the two basal veins that could sporadically dichotomise again. He reserved $C$. australis for specimens in which double-bifurcation was prominent (Retallack, 1983, noted that in this sense, C. australis would be generally restricted to the Triassic). McQueen (1956) accepted C. australis and remarked on the variability of the pinnule wing.

Herbst (1966) formalised the description of Cladophlebis patagonica but illustrated it with a line drawing of a frond entirely different from Frenguelli's (1947) concept of the species. In Herbst's (1966) illustration, the pinnules are (or are almost) touching each other. The veins all fork once, except for two possible indications of a second dichotomy. The veins are also dense and markedly reflexed. In his later review of Argentinian Cladophlebis, his figure (Herbst, 1971, fig. 3) of C. patagonica again showed neither the well-separated pinnules nor the basal twice-forking venation that was the basis for Frenguelli (1947) to separate a new species.

Johnston et al. (1987) argued that New Zealand Cladophlebis that had once-forking secondary venation had been commonly misidentified as $C$. australis, and instead, compared most records with C. indica (Sahni and Rao, 1933). Included in their concept of C. cf. C. indica was Arber's (1917) pl. 4 
fig. 1 specimen, which Frenguelli (1947) had figured as $C$. patagonica. The specimen of $C$. cf. $C$. indica illustrated by Johnston et al. (1987) from the Jurassic of Nelson is only the apex of a single pinnule, so does not show the full shape, pinnule separation, or basal venation that would be required to distinguish $C$. indica from Frenguelli's $C$. patagonica. However, Raine (1987) figured more complete material from the Jurassic of the Manganui Valley in the North Island with the closely spaced pinnules and consistently once-forking venation as in $C$. indica. Most recently, Thorn (2001) listed Cladophlebis cf. C. australis from Kawhia Harbour in the North Island.

Cladophlebis species occur in the Jurassic of Hope Bay and Botany Bay, Antarctica. Following the pioneering work of Halle (1913) there have been two major works revising the floras, by Gee (1989) and Rees and Cleal (2004). Both recognised only one entire-margined species, Halle's C. oblonga. Gee (1989) specifically regarded it as distinct from similar species elsewhere, such as $C$. australis, C. patagonica and C. indica.

A practical problem with the Catlins Coast material is that the venation is often faint and it is usually not straightforward to determine whether the veins dichotomise once or twice. Typically, the margins are also vague, and it is difficult to be sure that a slightly dentate margin is not an artefact of preservation. Despite this, the material I have collected appears to be entire-margined, with mostly singly-forking veins, but there are some that fork again. This later feature recalls Cladophlebis patagonica, although it is not restricted to the most basal veins as per Frenguelli (1947). However, many specimens have the remarkably long pinnules, and pinnules with a high length/width ratio, which Frenguelli associated with C. patagonica. In addition, most specimens have pinnules in which the base broadens apically. This feature is visible in Arber's (1917, pl. 4, fig. 1) specimen that Frenguelli (1947) placed in C. patagonica, but is absent on Herbst's $(1966,1971)$ specimen. Apically broadening pinnules were also associated with $C$. denticulata by both Gee (1989) and Birkenmajer and Ociepa (2008). However, both papers also agreed that the pinnule length/width ratio of $C$. denticulata was $<3$. Thus, even if the nature of the margin is obscure, the larger pinnule length/width ratio for the Catlins material rules out $C$. denticulata in most cases. In some of the Catlins Coast material the pinnae actually join to form a slight wing along the rachis, a feature noted for the Owaka Creek material by McQueen (1956). Raine's (1987)
North Island $C$. indica have a distinct wing between the pinnules, but do not show apically broadening pinnule bases. The concept of $C$. indica provided by Sahni and Rao (1933) was that the pinnules were mainly non-entire. However, the figures of the original Pecopteris indica (Oldham and Morris, 1863, pl. 27) do not show non entire margins, but many of the pinnules appear to overlap (similar to some extant New Zealand Blechnum) rather than be joined by a wing, and in the only figure showing a wing (2a) veins from adjacent pinnules meet in the sinus. These later two features suggest this material is distinct from any New Zealand fossils.

The present Catlins material agrees very well with that illustrated by Unger (1864) as Polypodium hochstetteri from the Waikato, a validly published name according to Mildenhall (1970). The drawing of this specimen appears to have taken care to show the sporadic second forking of veins, a wing between pinnules, and some apical broadening of the base.

Arber's specimen with well-separated pinnules that Frenguelli used as the basis of Cladophlebis patagonica appears to be aberrant, and the specimen then chosen by Herbst (1971) to represent the species differs from the New Zealand material in its dense and strongly curved veins.

However, based on the pinnule shape, instances of doubly-forking venation, at least some of the Catlins coast material is regarded as Cladophlebis patagonica. None of the material is consistent with $C$. australis, although $C$. indica cannot be ruled out.

\section{Cladophlebis patagonica Frenguelli, 1947 emend. Herbst, 1966 \\ Figure 4}

1864 Polypodium hochstetteri Unger, p. 5, figs. 1-2.

1886 Pecopteris obtusata Hector, fig. 30A (1).

1886 Pecopteris grandis Hector, fig. 30A (3).

1987 Cladophlebis indica (Oldham and Morris) Sahni and Rao; Raine, pl. 1, fig. 6.

1995 Cladophlebis australis (Morris) Seward; McLoughlin and Drinnan, p. 258, fig. 2F, fig. 3A, C.

2002 Cladophlebis sp. cf. C. patagonica Herbst McLoughlin et al. p. 15, fig. 9 A-E, fig. 10A.

Material. Black Point: LX0654, LX0655, LX1183, LX1184, LX1498, LX1499, Blue Cod Bay: LX0666, LX0680, Boat Harbour: LX1069, LX2070, Curio Bay: LX1074-1078, LX1080, LX1081, LX1083, LX1085-1089, LX1104, LX1226, LX1235, HaldaneCurio Bay Road: LX1213, Little Beach-01: LX1258, The Chasm: LX0660, Otara-21, Noted in the field, Otara-34: LX0683, LX1195, 1196, 1198, Owaka: 

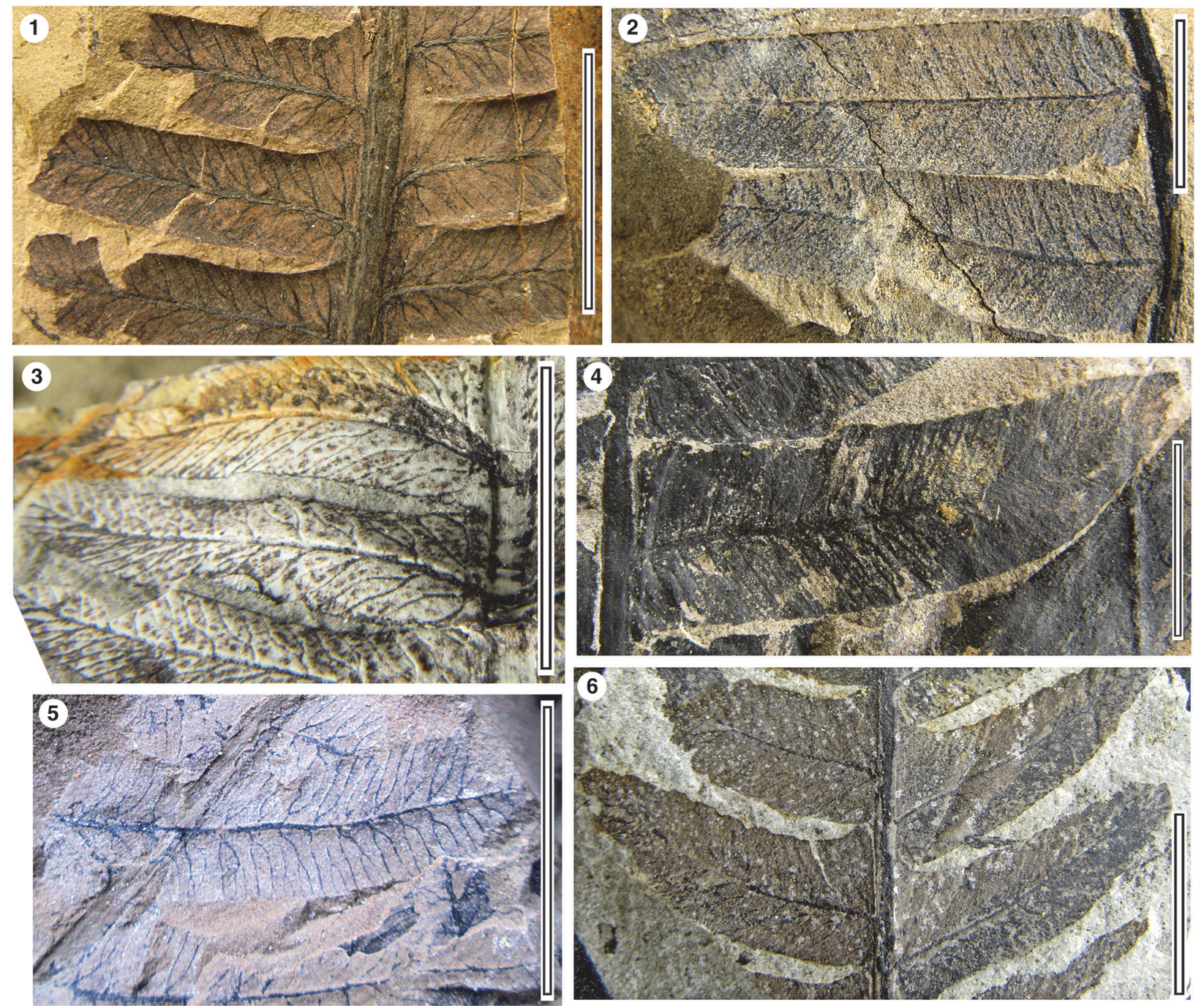

FIGURE 4. Cladophlebis patagonica pinnules. 1. LX1498, Black Point (Note the distinct apical broadening of the pinnule base); 2. LX1074, Curio Bay; 3. LX1197, Slope-02; 4. LX1069, The Boat Harbour; 5. LX1076, Curio Bay (Note that some of the veins dichotomise twice.); 6. LX2070, The Boat Harbour (Note the pronounced apical broadening of the pinnule base which continues to the adjacent pinnule as a 'wing'. All scale bars equal $10 \mathrm{~mm}$ ).

LX0671, Slope-02: LX0684, LX1134, LX1135, 1136, 1139, 1197.

Description. Fronds tripinnate, c. $1 \mathrm{~m}$ long. Pinnae length to around $120 \mathrm{~mm}$, pinnules subopposite lanceolate, length 13-33 mm, width 3-9 $\mathrm{mm}, \mathrm{L}: \mathrm{W}$ ratio 3.2-4.8, margin entire, apex acute, pinnule base broadening apically (Figure 4.1), margin decurrent on rachis apically and basally, margins of adjacent pinnules just touching on the rachis, or slightly out from it forming a wing (Figure 4.6), lateral veins dichotomising once, typically about onethird the distance from midrib to the margin, rarely a second time (Figure 4.5), midrib straight or slightly falcate, running smoothly to the apex, where its width becomes the same as the lateral veins.
Remarks. Despite the absence of fertile material, Cladophlebis patagonica most likely belongs in the Osmundaceae. In the Curio Bay - Slope Point region, permineralised stems attributed to Osmundaceae are common (Kidston and GwynneVaughan, 1907-10; Miller, 1967; Tidwell, 1994) as are spores of the family in the palynological record of the area (Thorn, 2001) and the broader New Zealand Jurassic (Raine et al., 2011). Very similar (possibly conspecific, but typically placed in $C$. australis or in no species) sterile foliage in the Gondwana Jurassic is either regarded as Osmundaceae (e.g., Gould, 1974; McLoughlin and Drinnan, 1995) or kept as 'family unknown' (Gee, 1989; Rees and Cleal, 2004). 


\section{Family DICKSONIACEAE Schomburgk, 1848} Coniopteris and Sphenopteris

Remarks. Edwards (1934) maintained that "With the possible exception of Cladophlebis australis [Coniopteris] is the most abundant fossil in nearly all the New Zealand Jurassic localities..." However, the boundaries of the genus are vague, particularly with respect to Sphenopteris, from which Brongniart (1849) segregated Coniopteris. Some workers restrict the use of Coniopteris to fertile material and use Sphenopteris for sterile, whereas others have posed various morphological criteria for segregation. For example, Arber (1917) identified both sterile Coniopteris and Sphenopteris from the Catlins coast, although it is unclear what his distinguishing criteria were. He appears to have followed Seward (1904), quoting him that for Coniopteris hymenophylloides, "Venation and form of the frond [is] of the Sphenopteris type". Other workers have cited various distinguishing characters, Medwell (1954, p. 86) wrote: "Coniopteris tends to have more bluntly rounded lobes than Sphenopteris, but the distinction is small." Douglas (1969, p. 85) considered that "Fertile S. warragulensis and Coniopteris specimens are easy to distinguish. The sori on the tips of the Coniopteris pinnules are much smaller and very rarely aggregated, and average about five per pinnule-S. warragulensis has one?rarely two sori per pinnule or indentation." Gee (1989, p. 170) regarded Sphenopteris as "a form genus established for pinnules which are constricted at the base, often attached by a short stalk, elliptical in outline, with a margin lobed or toothed, with lateral veins that diverge from the relatively straight or flexuous midvein at low angles singly or in groups." She used Coniopteris for similar, but fertile material. To McLoughlin and Drinnan (1995, p. 265) Sphenopteris was a "bipinnate frond and dissected pinnules with sinuous veins" and McLoughlin et al. (2002) described fertile Sphenopteris.

In the present work sterile material is regarded as Sphenopteris and fertile as Coniopteris. This follows Gee's (1989) concept of Sphenopteris as a typical form genus, but Coniopteris as a 'real' genus. In reality, the Catlins species are probably forms of the same taxon.

The present material is similar to Arber's Sphenopteris otagoensis and probably also to his sterile Coniopteris hymenophylloides. The Australian Sphenopteris travisii (Stirling, 1900; Drinnan and Chambers, 1986; McLoughlin et al., 2002) is regarded as identical and has priority. In terms of lobe shape and dissection, Catlins Sphenopteris do not compare well with any of the Hope Bay (Gee, 1989; Rees and Cleal, 2004) species. For instance, the pinnules are not reduced to wings of lamina surrounding the midvein and lateral veins as in S. bagualensis and S. nordenskjoeldii, but the basiscopic margins do taper gradually until they meet the proximal pinnule as per $S$. anderssonii. However, the pinnule lobes of $S$. andersonii appear much more rounded and more subdued on the basiscopic margin.

A single Catlins fertile specimen is regarded as Coniopteris. It has slightly narrower pinnules and pinnule lobes than Sphenopteris otagoensis and has a prominent round sorus at the end of each lobe. The form of the pinnules and aspect of the sori agree with $C$. murrayana as figured by Harris (1961). Furthermore, Gee (1989) identified Arber's (1917, text fig. 9) similar fertile Curio Bay Coniopteris hymenophylloides as C. murrayana and regarded it as "identical" with material from Hope Bay. Guy-Ohlsen (1979) also reported C. murrayana from Curio Bay, and it is regarded as a cosmopolitan species. Rees and Cleal (2004) dealt differently with the Hope Bay material. They identified a $C$. cf. murrayana and kept fertile specimens that had been placed into $C$. hymenophylloides by Halle (1913) and Gee (1989), as informal species of Coniopteris. Specimens identified as C. cf. murrayana by Rees and Cleal shows deeply dissected lobes and fewer lobes per pinnule ( 5 as compared with c. 7).

The Coniopteris murrayana specimen and Sphenopteris otagoensis documented here occur in the same bed and probably belong to be the same 'natural' taxon.

Genus CONIOPTERIS (fertile) Brogniart, 1849

Coniopteris murrayana Brogniart, 1849

Figure 5

1913 Coniopteris hymenophylloides Halle, pl. 3, 27, lower, 28, 28.

1917 Coniopteris hymenophylloides Arber, text fig. 9.

1989 Coniopteris murrayana (Brogn.) Brogniart, Gee, pl. 1, fig. 9.

Material. Slope Point-03: LX2066.

Description. Fertile secondary pinna, length unknown, at least $80 \mathrm{~mm}$. Tertiary pinnae length up to $41 \mathrm{~mm}$, width $10 \mathrm{~mm}$, arising at an angle of 45$63^{\circ}$, tapering from base. Pinnules 8-9 mm long, 3$4 \mathrm{~mm}$ wide, arising at an angle of $60-65^{\circ}$, lobes slightly reduced, most bearing a terminal sorus (Figure 5.1). Sorus round, c. $0.8 \mathrm{~mm}$ diameter (the same width as the pinnule lobe). 


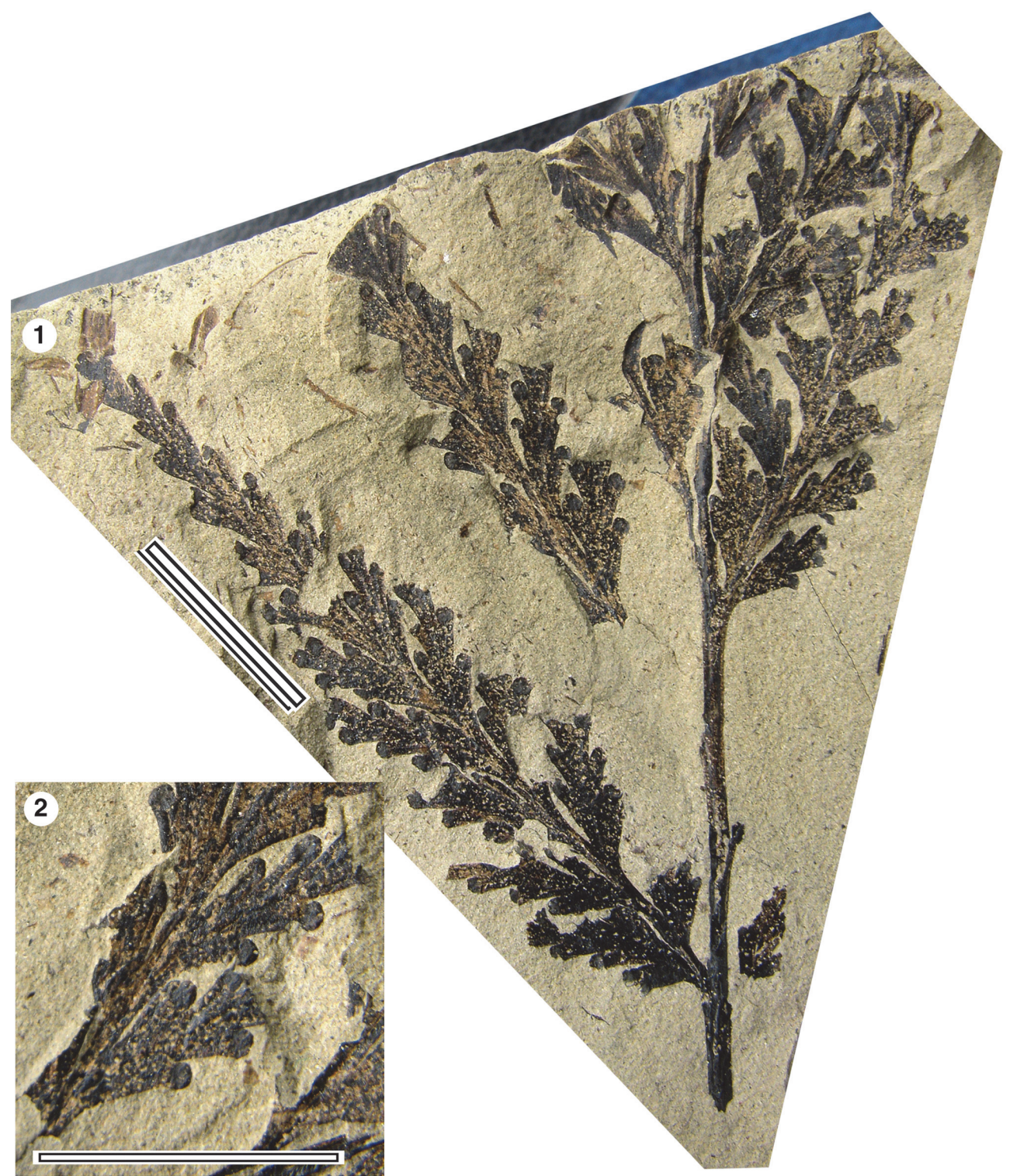

FIGURE 5. Coniopteris murrayana. 1. Fragment of fertile secondary pinna, LX2066, Slope-03 (scale bar equals 10 $\mathrm{mm}$ ); 2. Detail of fertile pinnules, LX2066, Slope-03 (scale bar equals $10 \mathrm{~mm}$ ).

Genus SPHENOPTERIS Sternberg, 1825

Sphenopteris travisii Stirling, 1900

\section{Figure 6}

1900 Sphenopteris travisii Stirling, p. 4, pl. 13, figs. $18,19$.

1917 Sphenopteris otagoensis Arber, pl. 1, figs. 5, 6, 8.

1917 Coniopteris hymenophylloides Arber, pl. 2, figs. 1, 2, 3.

1986 Sphenopteris travisii Stirling, Drinnan and Chambers, p. 29, figs. $15 \mathrm{H}$.

2002 Sphenopteris travisii Stirling ex Drinnan and Chambers; McLoughlin et al. p. 26, fig. 15.
Material. Black Point: LX1144-1146, LX1185, LX1186, LX1189, Blue Cod Bay: LX0665, LX1180, LX1181, Curio Bay: LX1100, LX1247, Slope Point01: LX1138, Slope Point-03: LX2066, LX2067.

Description. Fronds sterile, pinnae c. $60 \mathrm{~mm}$ long, tapering gradually. Pinnules alternate, arising at an angle of $40-40^{\circ}, 3-12 \mathrm{~mm}$ long, $1.2-4.7 \mathrm{~mm}$ wide, with two to three lobes on each side, tooth-like, with sharp apices, and separated by sharp sinuses. The acroscopic margin of pinnule is contracted, parallel to the pinna midrib. The basiscopic margin of each pinnule extends and narrows gradually toward its proximal neighbour forming a slight wing. Pinnule main vein decurrent on the main 

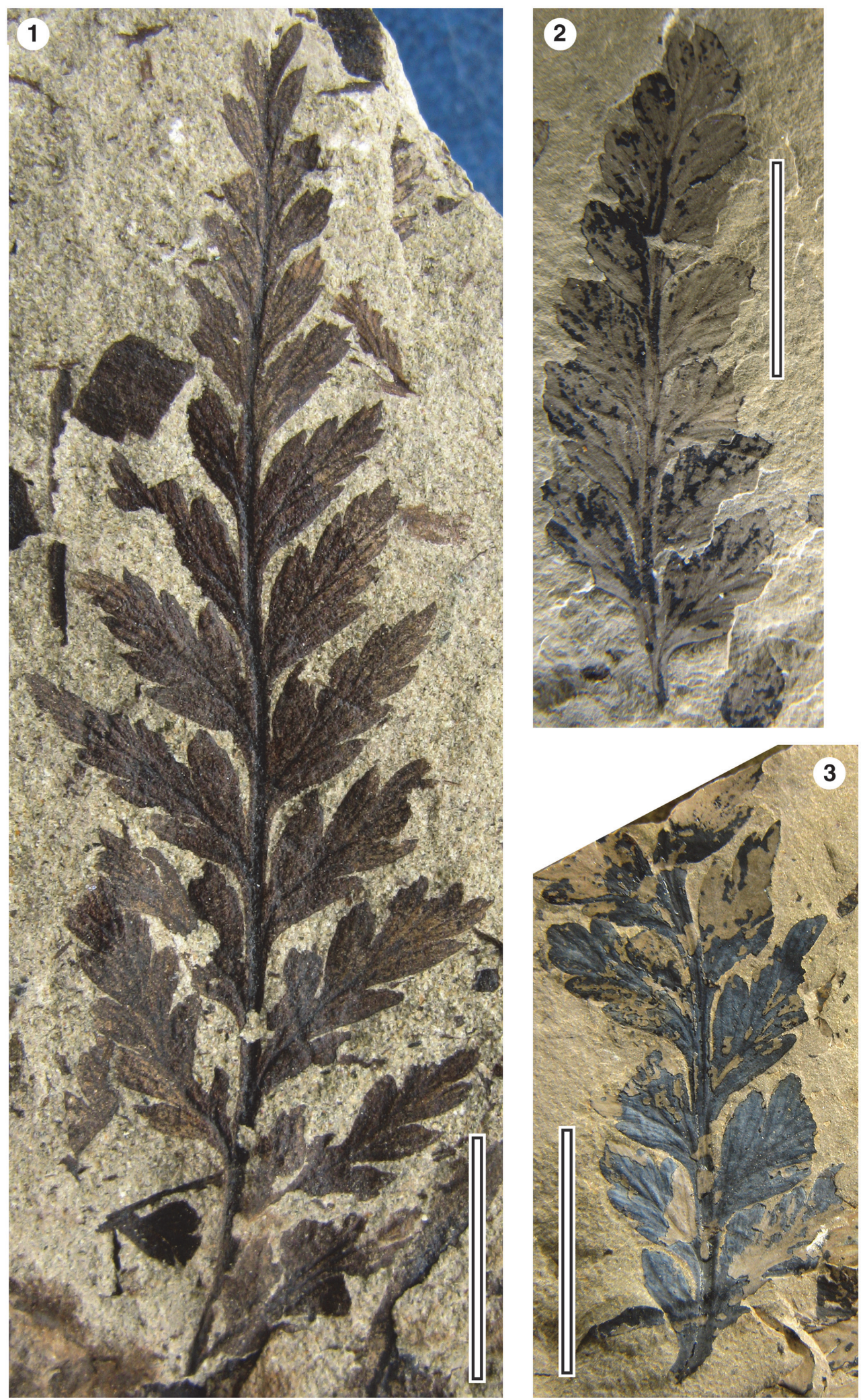

FIGURE 6. Sphenopteris travisii. 1. LX2067, Slope-03; 2. LX1180, Blue Cod Bay; 3. LX665 Blue Cod Bay. All scale bars equal $10 \mathrm{~mm}$. 


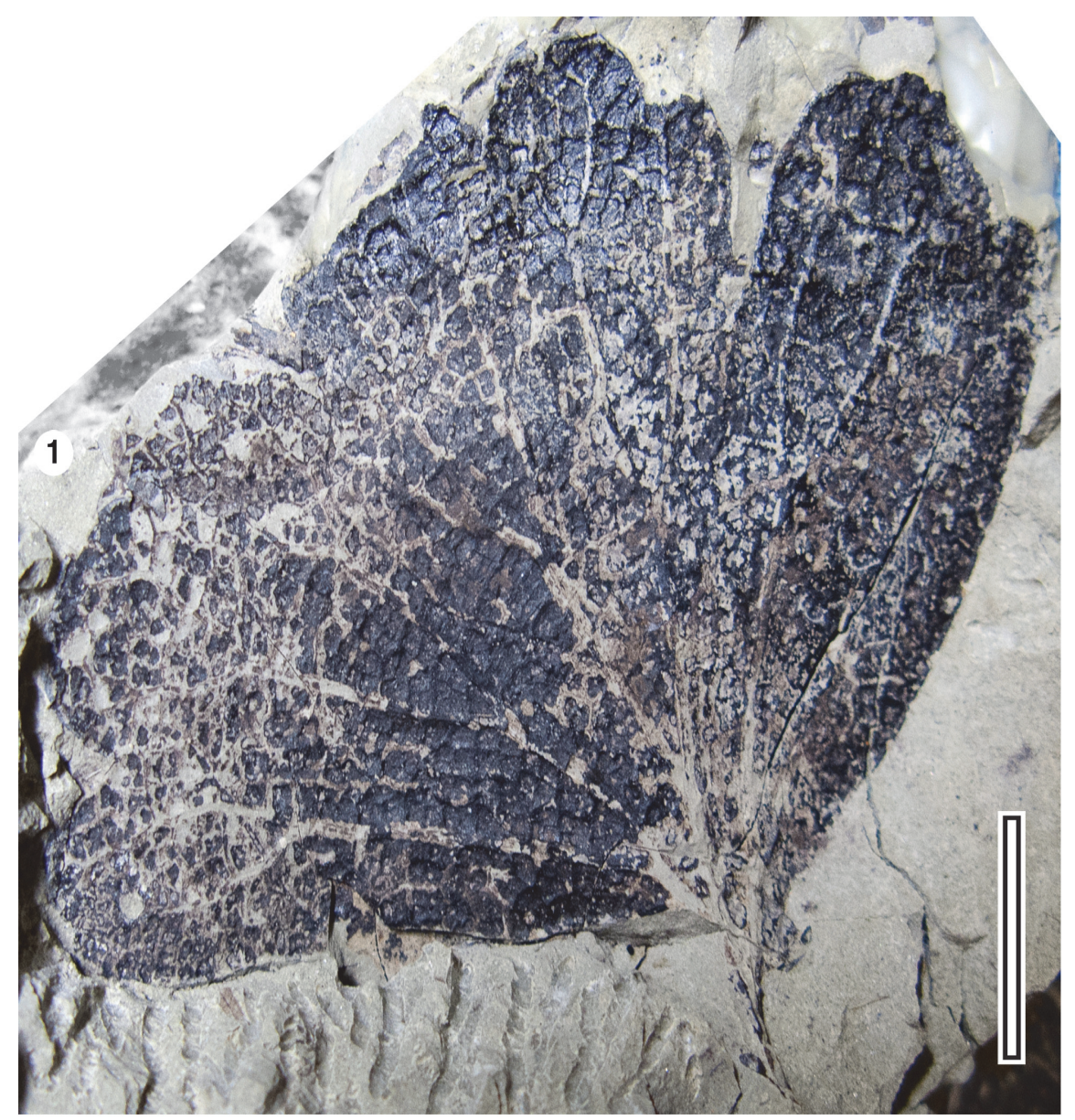

FIGURE 7. Hausmannia sp. 1. LX2361, Otara-36 (scale bar equals $10 \mathrm{~mm}$ ).

axis, with a zig-zag course within the pinnule and evanescing well before the pinnule apex.

\section{Family DIPTERIDACEAE Seward and Dale, 1901 Genus HAUSMANNIA Dunker, 1846 Hausmannia sp.}

Figure 7

Material. Otara-36: LX2361.

Description. Lamina presumably originally reniform, with a medial distal notch and other less prominent notches along the distal margin. Base truncate, at $90^{\circ}$ to the petiole. Height $40 \mathrm{~mm}$, preserved width $35 \mathrm{~mm}$, indicating an original width of c. $70 \mathrm{~mm}$. Sori not obvious. Petiole midvein bifurcates at the base, then at least three more times before the margin. Intervening lamina is divided into a reticulate, polygonal, mesh.

Remarks. On the basis of its reniform (or broadly fan-shaped) lamina, dichotomising major veins, and reticulate mesh of higher venation, a single specimen from Otara Beach is clearly a Hausmannia. Cantrill (1995) pointed out that Hausmannia is indistinguishable from extant Dipteris and is, there- fore, best regarded as an organ-genus of Dipteris. He noted that extant Dipteris show such a wide range of morphology that "few taxa could be recognised in the fossil record," although a few characters, including the degree of marginal lobing, could reliably distinguish species. Unfortunately, the margin of the new specimen is partially damaged, but what does remain indicates relatively shallow crenulations, with the exception of the apical sinus, clearly not deeply dissected. On that basis it is probably pointless to search for a "specific" match for the single specimen here, although the shape of the Otara Hausmannia compares favourably with fan-shaped Hausmannia from the Lower Cretaceous of Western Australia (McLoughlin, 1996; McLoughlin and Hill, 1996; McLoughlin and McNamara, 2001; Peyrot et al., 2019), and the Northern Territory (White, 1961). In contrast, it differs from the more distinctly reniform Middle Jurassic Hausmannia from the Clarence-Moreton Basin (Gould, 1980; McLoughlin and Drinnan, 1995) and the more deeply dissected Hausmannia wilkinsii 
from the Gilbert River Formation (Lower Cretaceous) of Cape York (Walkom, 1928).

Recent works covering the Dipteridaceae from the Australasian-Antarctic region include Herbst (1979), Rees (1993), Cantrill (1995) and Rees and Cleal (2004). The later reidentified all Dictyophyllum from the Antarctica Peninsula as Goeppertella, and Rees (1993) recognised Goeppertella from the New Zealand's Clent Hills. Dictyophyllum has been reported from the Catlins in the past (Arber, 1917; Herbst, 1979), but not encountered during the present study. Future study may indicate they are also Goeppertella. Rees (1993) regarded Goepertella as stratigraphically significant - for instance using its presence in the New Zealand Clent Hills assemblage to argue for a Late Triassic or Early Jurassic age, in contrast to Oliver et al. (1982) who proposed a Middle to Late Jurassic age (although note the Hunter et al., 2005, reassessment of the Botany Bay Group as mid Jurassic).

Family EQUISETACEAE Michaux, ex De Candolle, 1804

Genus EQUISETUM Linnaeus, 1753

Equisetum laterale Philipps emend. Gould, 1968 Figure 8

1829 Equisetum laterale Philipps, figs. 2, 3; pl. 1, figs. 1-22; pl. 2, figs. 1-18.

1917 Equisetites nicoli Arber, p. 26, plate 3, fig. 2.

1934 Equisetites nicoli Arber; Edwards, p. 90, pl. 4, fig. 3.

1968 Equisetum laterale Gould, p. 157, figs. 2, 3; pl. 1, figs. 1-22; pl. 2, figs. 1-18.

1989 Equisetum laterale Philipps emend. Gould, Gee, p. 157, pl. 1, figs. 3, 4, 5, 6 .

Material. Little Beach-04: LX1063-1067, Otara-20: Noted in the field, Otara-32: LX0657, Otara-33: LX0710-0712, Otara-34: LX0714-0716, 1496, 1497, Otara-35: LX2684, Owaka: LX0993-0995, 0999, 1001, 1003-1005, 1007-1010, 1166.

Description. Stems mostly $2.5-17 \mathrm{~mm}$ diameter (flattened), some specimens (LX1496) appear to be over $20 \mathrm{~mm}$, c. 14 leaves in a whorl, $6.0 \mathrm{~mm}$ long, $1.5 \mathrm{~mm}$ wide (Figure 8.2). Nodal diaphragm c. $10 \mathrm{~mm}$ in diameter, with 29 'spokes' (Figure 8.1).

Remarks. Two species of Equisetum have been described from the Southland Jurassic (as Equisetites), both of them falling within the Mesozoic group that has wheel-like nodal diaphragms (Harris, 1961). Arber (1917) described E. nicoli from the inland location of Mokoia. He compared it with the European E. laterale (as E. lateralis), saying "They may even be identical, though at present I should be inclined to regard them as specifically distinct." Arber (1917, p. 26) never clearly stated what the differences were with $E$. laterale, but said "There are, however, several points of agreement with $E$. laterale. The...nodal diaphrams...are similar..., though probably not identical. There are fewer "spokes in the wheel" of the New Zealand fossil." Arber did not describe the number of spokes, but his figures show about 18-19.

Subsequently, Edwards (1934) described Equisetum hollowayi from a "roadside cutting about $1 / 2$ mile inland from Curio Bay." It differed from $E$. nicoli in being "smaller in all of its parts" and "fewer and very much shorter leaves in the whorl and fewer "spokes" in the nodal diaphragm. The stems were less than $10 \mathrm{~mm}$ in diameter and diaphragms 2-4 mm in diameter with 9-14 spokes. Gould (1968) regarded $E$ nicoli as "closely comparable" to E. laterale, a species that Gee (1989, p. 158) noted is "known from Mesozoic sediments all around the world, particularly in the Australasian area."

The type horizon of Equisetum hollowayi has not been relocated, but Equisetum is present at other localities. A single diaphragm from the Otara coast has 29 "spokes" in the nodal diaphram which is about $10 \mathrm{~mm}$ in diameter. This nodal diaphragm is thus much larger than E. hollowayi and with more than twice the number of nodal spokes. Equisetites nicoli has a comparable nodal diaphragm diameter, although the number of spokes is slightly less. The present fossil is comparable to $E$. laterale in this respect. Given Arber's (1917) vague criteria for why $E$. nicoli was distinct from $E$. laterale, plus the widespread nature of the latter as currently understood, it seems pragmatic to regard E. nicoli and the new material as $E$. laterale.

Equisteum fossils from the Miocene of $\mathrm{New}$ Zealand (Pole and McLoughlin, 2017) have much broader stems, many more leaves, and no diaphragms.

Class CYCADOPSIDA sensu Ruggiero et al., 2015 Order BENNETTITALES Engler, 1892 and CYCADALES Persoon ex Berchtold and Presl, 1820

Remarks. Although they have broadly similar external foliage morphology the 'cycadophytes' were recognised as including two unrelated groups, the Bennettitales and Cycadales, once cuticular morphology was employed. This has clarified the position of various genera, but rather than come up with a parallel system for dealing with remains without cuticle, attention has also focussed on morphological characters to differentiate them. There are now several slightly different 

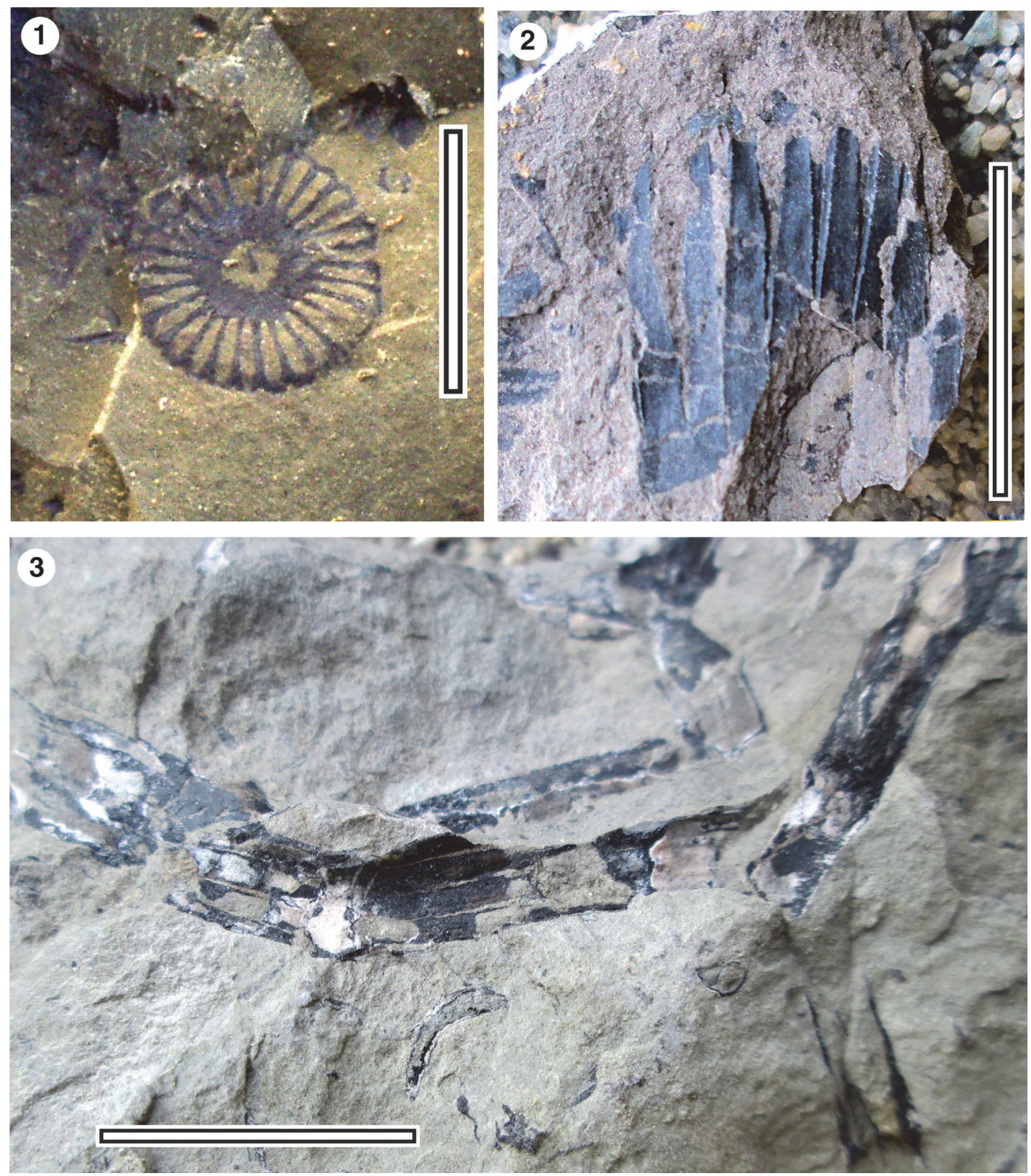

FIGURE 8. Equisetum laterale. 1. Diaphragm, LX2684, Otara-35; 2. Leaf sheath, LX1008, Owaka; 3. Possible rhizome, LX1066, Little Bay-01. All scale bars equal $10 \mathrm{~mm}$.

approaches for this (Harris, 1969a; Person and Delevoryas, 1982; Gee, 1989, Watson and Sincock, 1992; Rees and Cleal, 2004). All include the leaflet base as an important character although Rees and Cleal (2004) emphasised venation as more reliable.

Genus OTOZAMITES Braun, 1843 emend. Watson and Sincock, 1992

Otozamites douglasii Drinnan in McLoughlin, Tosolini, Nagalingum and Drinnan, 2002 Figure 9
1917 Ptilophyllum acutifolium Morris; Arber, p. 53, pl. 11, figs. 1, 2, 5 .

2002 Otozamites douglasii Drinnan; McLoughlin et al., p. 47, fig. 32.

Material. Black Point: LX1191, Blue Cod Bay: LX0679, 0681, Curio Bay: LX1229-1231, Otara36: LX2362, Slope-01: LX0656, Slope-04: Noted in the field.

Description. Fronds elongate, over $200 \mathrm{~mm}$ long (Figure 9.1), pinnules adaxialy inserted, at around $60-70^{\circ}, 13-14 \mathrm{~mm}$ long, $2.7-4.3 \mathrm{~mm}$ wide, apex acute, acroscopic margin straight or slightly con- 

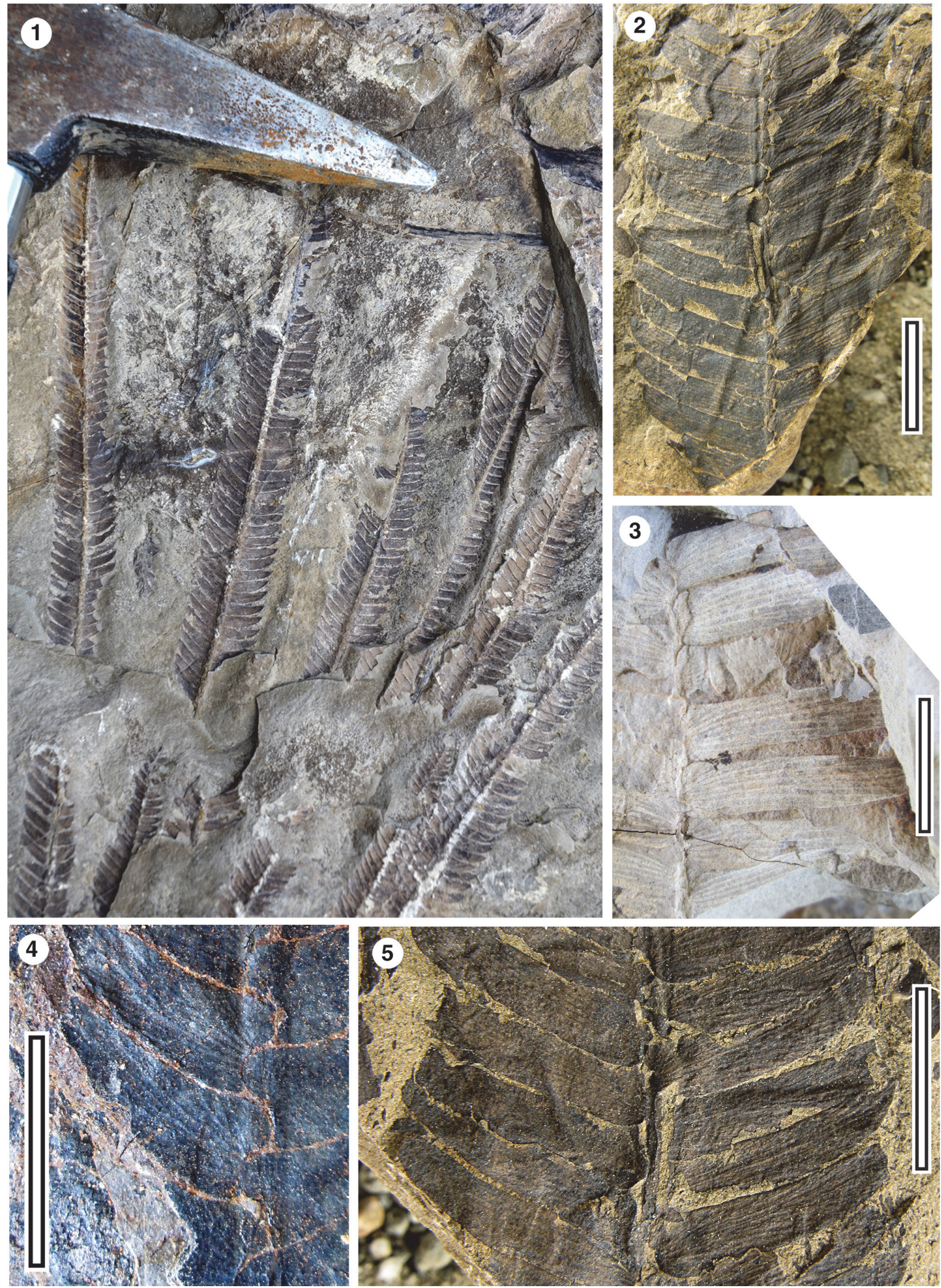

FIGURE 9. Otozamites douglasii 1. Photographed in the field, Slope-04; 2. LX1231, Curio Bay; 3. LX656, Slope-01, with slightly auriculate acroscopic margin of the pinnule bases; 4. LX1191, Black Point, showing distinctly auriculate acroscopic margin of the pinnule bases; 5. LX1231, Curio Bay, with contracted basiscopic margin of the pinnule bases. All scale bars equal $10 \mathrm{~mm}$. 
cave, basiscopic margin convex (Figure 9.1), acroscopic margin of leaflet base slightly or distinctly auriculate (Figure 9.3,4) and sometimes slightly imbricate (Figure 9.5), basiscopic pinnule edges distinctly contracted (Figure 9.3), veins 6-9, sometimes radiating from base (Figure 9.4), or acroscopic veins, either curving slightly acropetally, or running shortly to the margin.

Remarks. Several specimens have adaxialy inserted leaflet bases some of which are slightly imbricate at the base. These appear to be conspecific with what Arber (1917) illustrated as Ptilophyllum acutifolium. However, in neither case are basiscopic leaflet edges decurrent, but distinctly contracted (Figure 9.3), thus placement in Ptilophyllum is inappropriate (Halle, 1913; Harris, 1969; Watson and Sincock, 1992). In addition, the acroscopic margin of leaflet bases is slightly or distinctly auriculate (Figure 9.3), a character that is generally regarded as indicating Otozamites. Rees and Cleal (2004) cautioned that the leaflet bases could be distorted during taphonomic processes and that acroscopic veins curving acropetally was a more reliable character of Otozamites and would clarify any confusion with Zamites. There is no indication of leaftlet distortion in the Catlins material and, in the present specimens, the acroscopic veins either curve slightly acropetally, run shortly to the margin, but in one specimen (Figure 9.4), more clearly radiate. Thus, the material described here and Arber's (1917) Ptilophyllum acutifolium are assigned to Otozamites, a move already suggested by Cantrill (2000). Rees and Cleal (2004) argued the distinction between Ptilophyllum and Otozamites was probably artificial and that they "likely belonged to a 'natural' genus."

In terms of pinnule shape and venation, the closest morphological match of the Catlins material is with Otozamites douglasii from the Lower Cretaceous of Victoria (McLoughlin et al., 2002), and although epidermal details are needed to be sure, the Catlins material is assigned to that species. However, there may be more than one species. For example, the $O$. linearis illustrated from Antarctica by Gee (1989) tens to have a higher pinnule L/W ratio than the Catlins material, although Bomfleur et al. (2011) documented a wider range of pinnule shape. Those Otozamites differ from most of the Catlins Coast Otozamites in their strongly radiating veins. However, one fragmentary Catlins specimen does show distinctly radiating veins (and also has a more prominent auricle).

Genus PSEUDOCTENIS Seward emend. Watson and Sincock, 1992
Pseudoctenis? ensiformis Halle, 1913

Figure 10

1886 Pterophyllum matauriensis Hector, p. 66, textfig. 30A.

1913 Pseudoctenis ensiformis Halle, pl. 6, fig. 8.

1917 Pterophyllum matauriensis Hector; Arber, p. 52, pl. 9, fig. 2, pl. 12, fig. 1.

1934 Pterophyllum matauraense Hector; Edwards, $p$. 99.

1989 Pseudoctenis ensiformis Halle; Gee, p. 24, pl. 5, fig. 18.

2004 Pseudoctenis? ensiformis Halle; Rees and Cleal, p. 37, pl. 11, figs. 1-4, text fig. 4.

Material. Haldane-Curio Bay Road: LX1199-1207, LX1210, LX1212, LX1214, LX1215.

Description. Leaf apparently once pinnate, pinnae arising laterally on rachis. Rachis 1-3 mm wide. Pinnae alternate, arising at c. $90^{\circ}$, separate or connected by basal lamina. Pinnae separated by $3-12$ $\mathrm{mm}$ away from the rachis. Pinna margins entire, near-parallel beyond the base. Pinna bases expanded basiscopically and acroscopically. Pinna apices unknown. Pinnae $>45 \mathrm{~mm}$ long, width 6.5-9 $\mathrm{mm}$ beyond the base. Pinna venation prominent, 4-6 veins at pinna base, then commonly dichotomising, or sparsely anastomosing at varying distances from the rachis, to 8-9 veins across pinna width. Otherwise, veins. Basiscopic veins curving parallel to basiscopic margin, acroscopic veins parallel to acroscopic margin, then all becoming subparallel.

Remarks. A collection of frond fragments from a road cut behind Curio Bay have laterally inserted leaflets with expanded bases, both dichotomising and anastomosing veins and some striations on the rachis. On gross morphology these are likely the same species as Pterophyllum matauriensis, (Hector, 1886) and figured by Arber (1917), from the Mataura River, about $60 \mathrm{~km}$ inland from Curio Bay, although without mention of anastomosing veins.

Halle (1913) placed similar Jurassic material from Hope Bay, Antarctica, into Pseudoctenis ensiformis. He noted that Pseudoctenis has "occasional" anastomoses, Ctenis has regular anastomoses, whereas Pterophyllum has none. Halle (1913, p. 51) wrote that the characteristic feature of the Hope Bay material was the "widening of the pinnae at the base, both edges bending outwards and sometimes nearly joining those of the next lower and higher pinnae, thus forming a rounded sinus. To this feature corresponds a peculiarity in the course of the veins: the uppermost one or two veins in each pinna do not bend downwards 

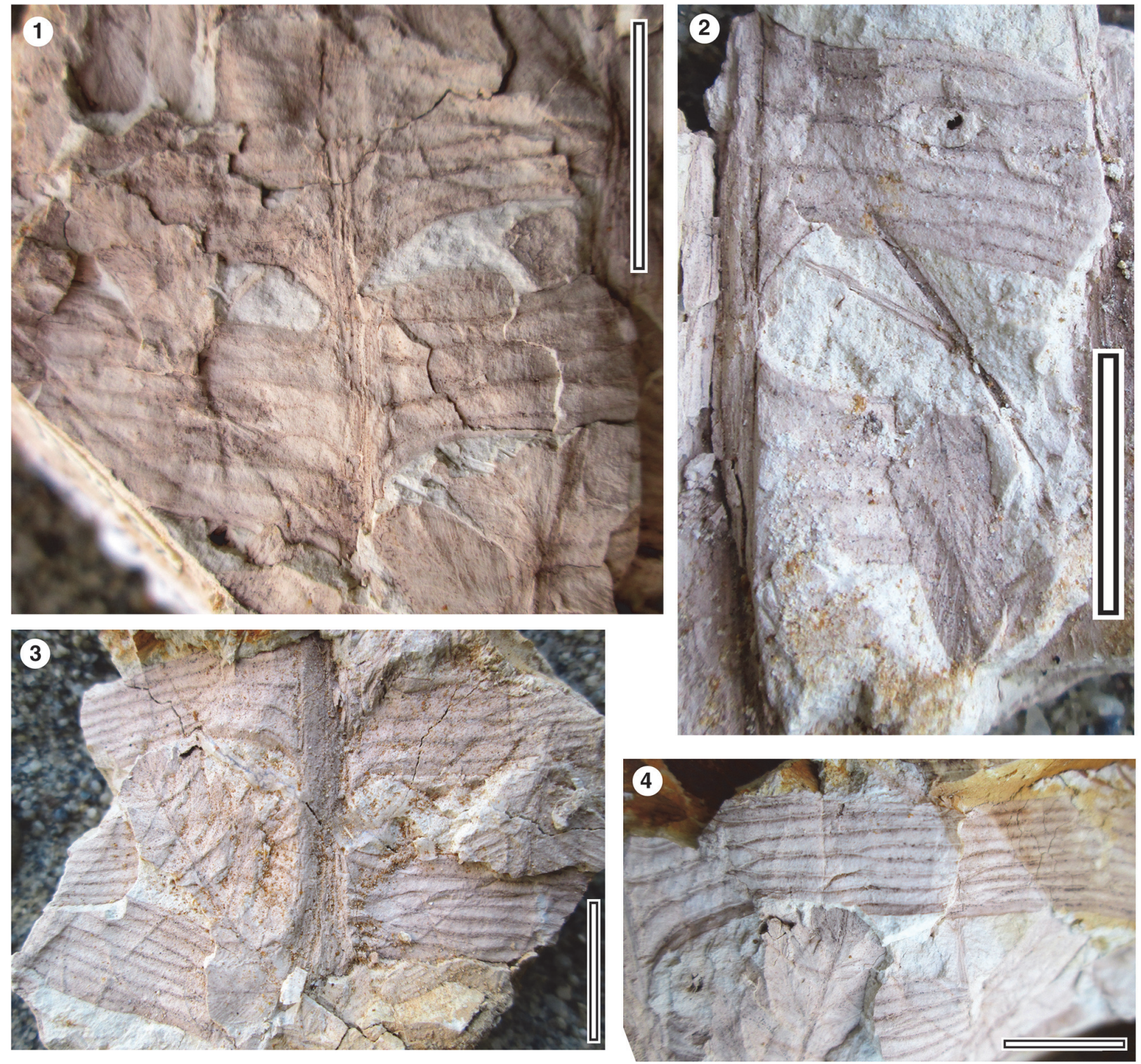

FIGURE 10. Pseudoctenis? ensiformis 1. LX1204; 2. LX1212; 3. LX1206; 4. LX1214. All Haldane-Curio Bay Road, scale bars equal $10 \mathrm{~mm}$.

when joining the rachis, as do the others, but upwards, parallel with the distal edge of the pinna." These specific features and the overall form of his material are very similar to the Curio Bay material and are probably conspecific.

Gee's (1989) treatment of the Hope Bay material agreed with Halle's (1913) placement in Pseudoctenis. She drew attention to Pterophyllum medlicottianum from India (Bose and Banerji 1981) that was similar in "general aspect, but differing in its unforking veins." However, Rees and Cleal (2004), working on additional Hope Bay material, and following Harris (1964, 1969a), stated that both Pseudoctenis (a cycad) and Pterophyllum (a bennettitalean) "rarely if ever show anastomosing veins." They placed some Hope Bay material into Ctenis, especially because of its frequently anastomosing venation. However, this is quite dissimilar to the Curio Bay material in having lobed margins. They provisionally kept Halle's (1913) taxon in Pseudoctenis but suffixed it with '?' to indicate they could not be sure it was a true cycad. The material studied by Rees and Cleal (2004) showed "mainly simple veins" in contrast to Gee's, which she said bifurcated "occasionally and unpredictably, from 0 to 4 , usually 3 , times per pinna, often at the pinna base." Rees and Cleal (2004) emphasised the similarities of the Hope Bay material with the Indian Pterophyllum medlicottianum, but widened the net to two other species, Pt. footeanum and Pt. morr- 
sianum, which only differed in having sporadic dichotomies. They argued there was a "strong possibility" that all four taxa would prove synonymous.

Following Thomas (1930), Watson and Sincock (1992) restricted Pterophyllum to species that have known Bennettitalean cuticle, and specifically excluded anastomosing venation in their diagnosis. More recent work on the genera includes Pott and Krings (2010), who noted that Ctenis and Pseudoctenis are "similar in macromorphology" but (following Seward, 1911) they were "easily distinguishable" on account of anastomoses in Ctenis. They also emphasised the striate nature of the rachis in Pterophyllum.

The Curio Bay material is very fragmented, but even in those fragments the dichotomies and anastomoses are apparent, and hardly "rare" (although the anastomoses are not common enough to regard them as a Ctenis). They appear to add to the evidence of Pseudoctenis? ensiformis, Pterophyllum medlicottianum, Pt. Footeanum, and $P$ t. morrsianum being synonymous, with the degree of both dichotomies and anastomoses being variable. The Curio Bay material is regarded as Pseudoctenis? ensiformis, following Rees and Cleal (2004).

Genus RINTOULIA McLoughlin, Tosolini, Nagalingum, and Drinnan, 2002

Rintoulia pectinata (Hector) McLoughlin, Tosolini, Nagalingum, and Drinnan, 2002

\section{Figure 11}

1886 Lomarites pectinata Hector, fig. 30A (5).

1917 Microphyllopteris pectinata (Hector) Arber, $p$. 40, pl. 7, figs. 3, 4, 6, 8, 10, 11.

1919 Microphyllopteris pectinata (Hector); Walkom, p. 186 , pl. 8, figs. 1,4 .

1981 Pachydermophyllum pinnatum (Walkom) Retallack, p. 176.

2002 Rintoulia pectinata (Hector) McLoughlin, Tosolini, Nagalingum, and Drinnan.

Material. Curio Bay: LX1233, LX1238, Little Beach-03: LX1021, LX1029, Owaka: LX669.

Description. Frond elongate, $>30 \mathrm{~mm}$ long. Axis 1-1.7 mm diameter. Pinnules semicircular or ovate, attached by complete base to rachis, 1-5 $\mathrm{mm}$ long, 2-4 mm wide, separated by $0.5-1.0 \mathrm{~mm}$. Remarks. The 'saga' of this morphology highlights issues of trying to deal with fossils that have neither fertile structures nor cuticle. In this case the basic morphology has been attributed not only to several families of ferns, but also to gymnosperms. Arber (1917) considered that some New Zealand material would be "unhesitatingly" referred to Gleichenites by "most authors." To him there was no doubt that the fossils were ferns and related to present-day Gleicheniaceae. But he regarded Gleichenites as a genus that was "incapable of being defined compactly and concisely." He therefore introduced a new genus, Microphyllopteris, for fronds that had (among other characters) pinnules "very small, subcircular or ovate, closely set, broadest at the base, and attached by their whole base." There was evidently a little uncertainty in his own mind at the generic limits of Microphyllopteris. He remarked on a specimen that he described as Microphyllopteris sp. from Owaka, that "It is possible that this specimen should be more correctly referred to the genus Thinnfeldia, though I am inclined to regard it as an example of Microphyllopteris, on account of the small size of the pinnules." Arber (1917) then identified three species of Thinnfeldia (a gymnosperm) from Owaka, T. Iancifolia, T. feistmanteli, and T. odontopteroides. There are probably intergradations of these Owaka 'species', and possibly with Microphyllopteris as well. Edwards (1934) suggested that some of Arber's (1917) Microphyllopteris pectinata may even be Cladophlebis reversa. Since then, Doludenko (1971) and Doludenko et al. (1998) have placed Thinnfeldia into synonymy with Pachypteris.

Retallack (1981), placed several of Arber's (1917, p. 40, pl. 2, fig. 10, pl. 7, figs. 3, 4, 6, 8, 10, 11 only) specimens of Microphyllopteris pectinata into Pachydermophyllum (as Pachydermophyllum pinnatum (Walkom) Retallack), a genus explicitly including cuticular details in its definition (Thomas and Bose, 1955). However, McLoughlin et al. (2002) subsequently placed most of Arber's specimens into Rintoulia pectinata (Hector) McLoughlin, Tosolini, Nagalingum, and Drinnan. They excluded two specimens (Arber, 1917, pl. 7, figs. 5 and 9), which are at least twice pinnate. These two specimens compare with Archangelskya.

Nagalingum and Cantrill (2006) proposed that Gleichenia-like fern fronds should be classified in two genera: Gleicheniaceaephyllum, if they could be referred to the Gleicheniaceae, or Microphyllopteris, "for ferns that cannot be ascribed conclusively to Gleicheniaceae." Microphyllopteris was then considered by Miller and Hickey (2008), who emended its diagnosis and suggested its use be restricted to true gleicheniaceous fronds.

Vera and Passalia (2012) argued that Microphyllopteris is illegitimate, as the type material had been reassigned by Rettalack (1981). They introduced a new fern genus Korallipteris, stating: “... since [Microphyllopteris] cannot be used for fossil 

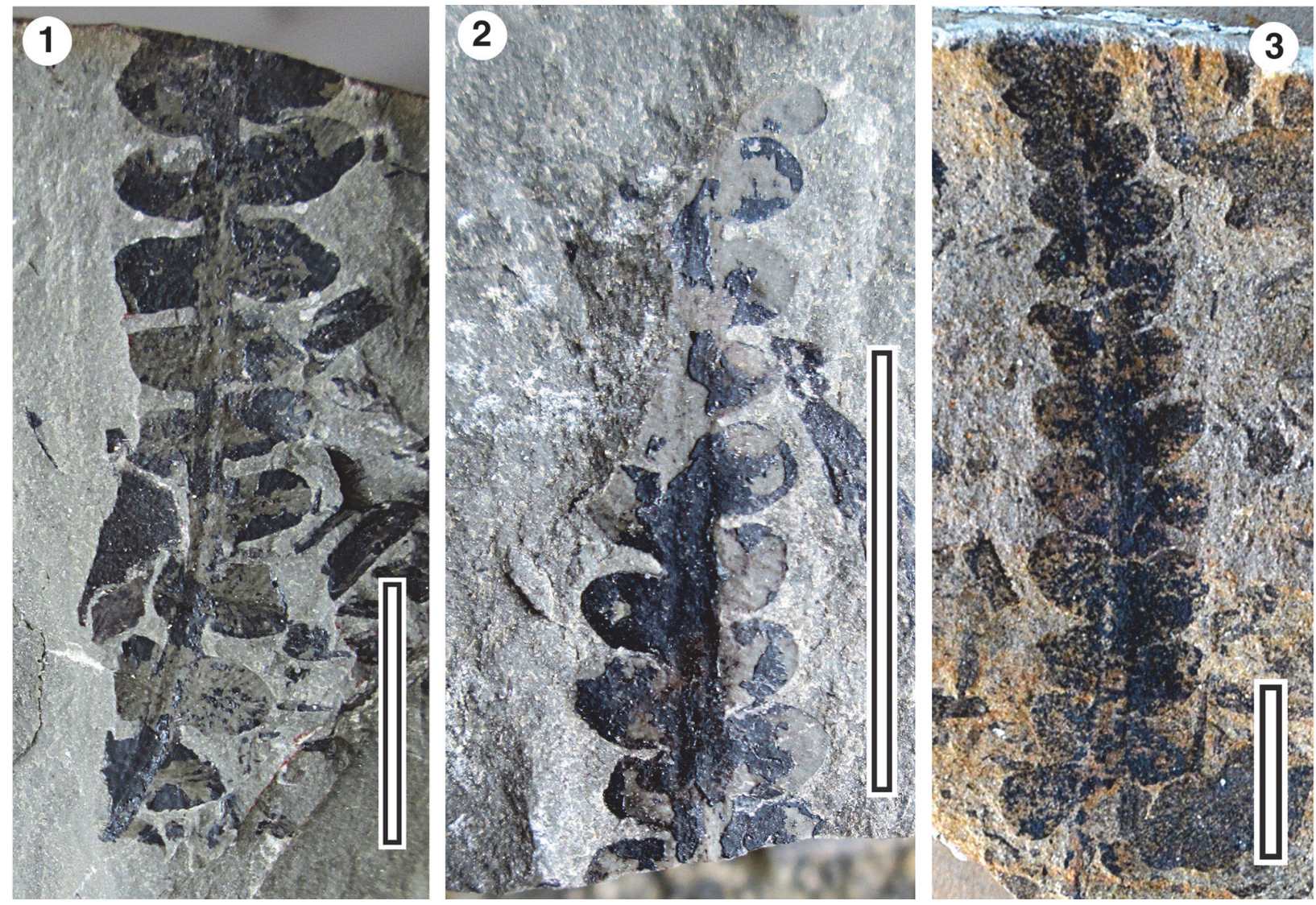

FIGURE 11. Rintoulia pectinata 1. LX1029, Little Bay-03; 2. LX1021, Little Bay-03; 3. LX669, Owaka. All scale bars equal $10 \mathrm{~mm}$.

ferns, we propose Korallipteris nov. gen. as a "replacement."

Underlying much of this debate is an issue of intent - whether the material is thought to be a fern or a pteridosperm. In a strict sense, Microphyllopteris appears to have clear priority for material with semicircular pinnules, but which is sterile, has no cuticle, and higher affinities that are not known. However, in the interests of some stability, Rintoulia is used for the Catlins material, following McLoughlin et al. (2002).

Based on this concept of Rintoulia, it is common in both the Jurassic (Walkom, 1919, 1921; Jansson et al., 2008) and Early Cretaceous (White, 1961; Douglas, 1969; McLoughlin et al., 2002) of Australia and also appears to be present in the Lower Cretaceous of India (Sah, 1965; Bose and Sah, 1968). Note that on the basis of spores, the Gleicheniaceae were clearly present in the New Zealand Mesozoic (Raine, 2011).

Genus ARCHANGELSKYA Herbst emend. Rees and Cleal, 1993

Archangelskya furcata (Halle) Herbst emend. Rees and Cleal, 1993

Figure 12

1989 Archangelskya furcata (Halle) Herbst emend. Rees and Cleal; Gee, fig. 38.

2004 Archangelskya furcata (Halle) Herbst emend. Rees and Cleal; Rees and Cleal, pl. 22.

Material. Owaka: LX0672, LX0673.

Description. Frond bipinnate. Primary axis c. 2 $\mathrm{mm}$ diameter. Pinnules rhombic or almost fanshaped attached by a narrow base. 8-11 $\mathrm{mm}$ long, 4-5 mm wide. Acroscopic basal margin contracted such that the basal, apical margin of the pinnule is more or less parallel to the axis, basiscopic basal margin decurrent, but not connecting to adjacent pinnule as a wing. Venation faint but appears to generally radiate from attachment.

Remarks. Two fragments from Owaka have the distinct pinnule shape of Archangelskya, and specifically with $A$. furcata (see Gee, 1989; Rees and Cleal, 2004; Parica et al., 2007). The pinnule shape is widely characterised as 'polymorphic'.

Genus PACHYDERMOPHYLLUM Thomas and Bose, 1955 

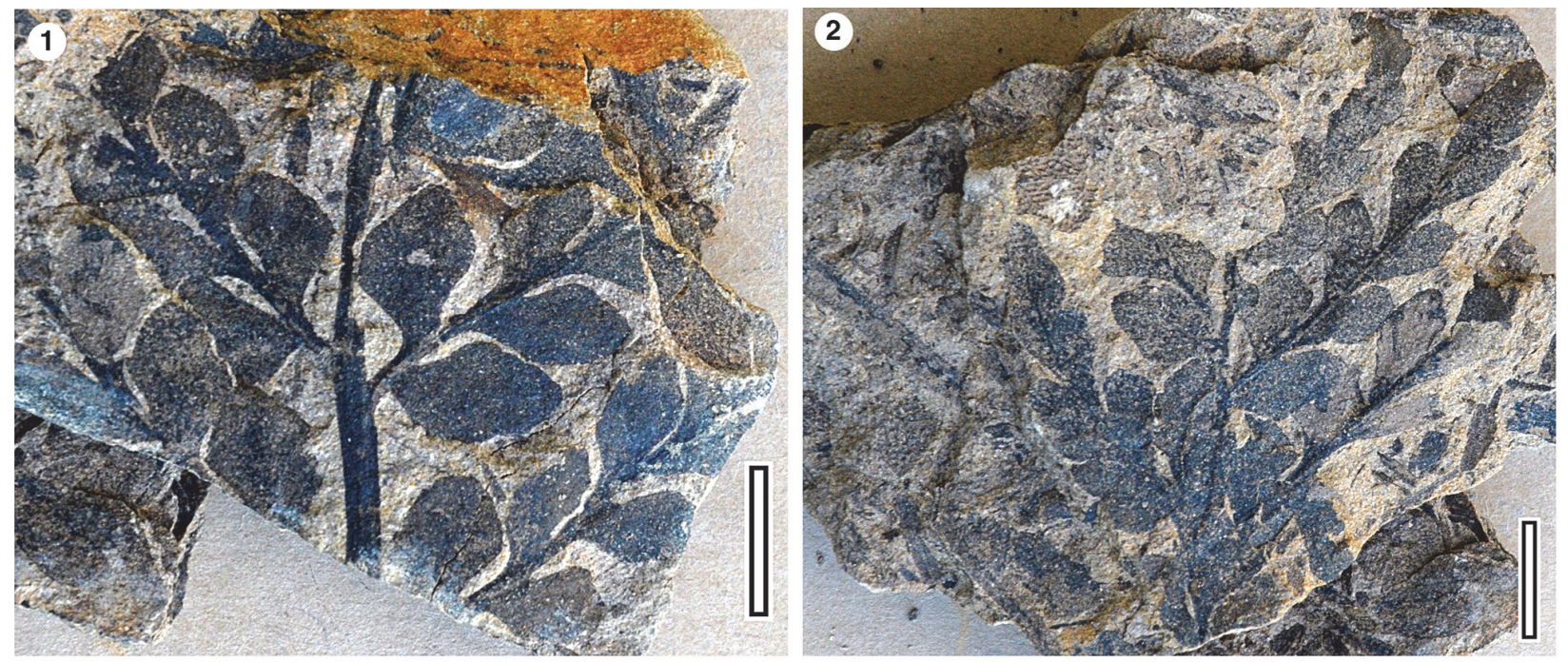

FIGURE 12. Archangelskya furcata. 1. LX0672, Owaka; 2. LX0673, Owaka. All scale bars equal $10 \mathrm{~mm}$.

Pachydermophyllum austropapillosum (Douglas, 1969) McLoughlin and Nagalingum, 2002

\section{Figure 13}

1969 Pachypteris austropapillosa Douglas, figs. 2527.

2002 Pachydermophyllum austropapillosum (Douglas, 1969) McLoughlin and Nagalingum fig. 39.

Material. Little Beach-03: LX1014, The Chasm: LX0658, LX0659.

Description. Frond pinnate, elliptical in overall outline, with longest pinnules in the middle, $>50 \mathrm{~mm}$ long. Rachis prominent, with central ridge/depression. Pinnules 12-13 mm long, 2.3-3.8 mm wide, well-spaced, about $2.3-2.5 \mathrm{~mm}$, attached laterally, at near right angles (c. $70-90^{\circ}$ ), connected by a narrow flange along the rachis, mostly straight, basiscopic margins prominently decurrent, acroscopic margins curving basally, margins roughly parallel, but crenulate, one central vein.

Remarks. Fronds at The Chasm are similar to Victorian Early Cretaceous material that Douglas (1969) placed in a new species, Pachypteris austropapillosa and which was later transferred to Pachydermophyllum by McLoughlin et al. (2002). Similar material (as Pachypteris) has also been listed in the Walloon Coal Measures (Gould, 1974, 1975, 1980; P. pinnata, P. cf. austropapillosa, P. crassa).

\section{Class Uncertain}

Family PENTOXYLACEAE Sahni, 1948

Genus TAENIOPTERIS Brongniart, 1832

Remarks. Taeniopteris is the second most common taxa of the Catlins coast. The use of Taeniopteris in the present work follows Harris (1932) and
Rees and Cleal (2004), who reserve it for material lacking anatomical details, which might otherwise place it in genera such as Macrotaeniopteris, Nilssonia, Nilssoniopteris, or Nipaniophyllum. On this basis, Rees and Cleal (2004) placed their Hope Bay material in Taeniopteris.

Arber (1917) recognised four species of Taeniopteris in the New Zealand Jurassic: T. crassinervis, T. daintreei, T. thomsoniana, and T. vittata. These were based on features of venation - its conspicuousness, spacing, and whether the veins forked near the midrib or within the lamina. Edwards (1934) regarded T. daintreei (McCoy, 1875 ) as a mis-print for the older (McClelland, 1850) name of $T$. spatulata. He also suggested that Arber's (1917) Curio Bay T. vittata were an extreme form of $T$. spatulata, although made no comment that $T$. vittata is an even older name. Mildenhall (1970) included both $T$. daintreei and $T$. spatulata in his list of valid names, but repeated Edwards' (1934) point that $T$. daintreei was probably a misprint for $T$. spatulata. Since the reviews by Douglas (1969) and then Drinnan and Chamber (1985) of $T$. daintreei, this name has been widely used for Australasian material, although they did not specifically deal with the issue of $T$. spatulata.

The most widespread Taeniopteris in the Jurassic of the Catlins Coast (exemplified by material from Curio Bay) has leaf widths ranging from about $5 \mathrm{~mm}$ to at least $27 \mathrm{~mm}$, but too few specimens are available from any single locality to recognise a mode. A quantitative study by Blaschke and Grant-Mackie (1976) documented distinctly different Taeniopteris widths in collections from the Jurassic of Port Waikato and Clent Hills. The nar- 

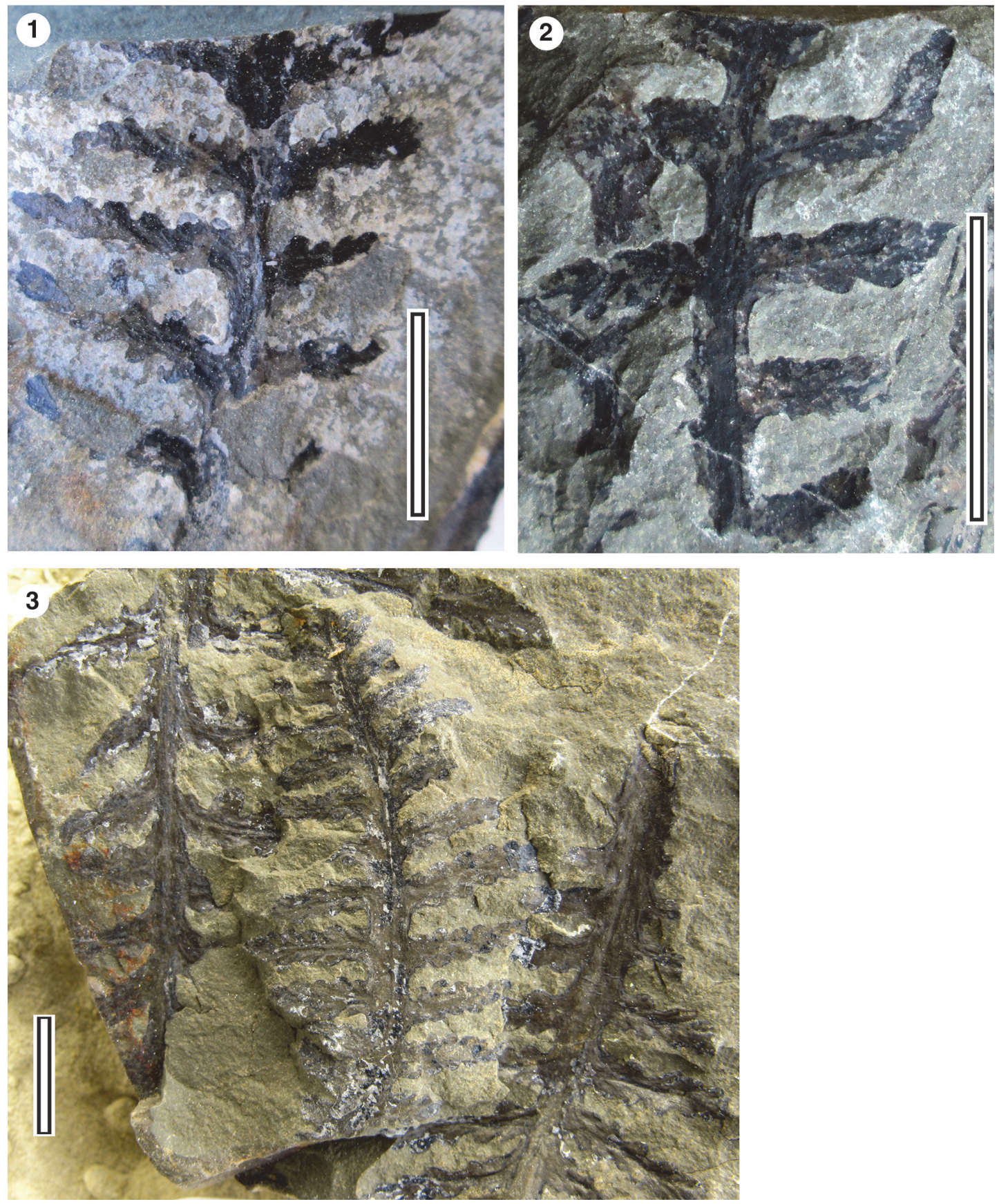

FIGURE 13. Pachydermophyllum austropapillosum 1. LX659, The Chasm; 2. LX1014, Little-03; 3. LX658, The Chasm. All scale bars equal $10 \mathrm{~mm}$.

rower (mostly 3-13 $\mathrm{mm}$ ) Port Waikato specimens were included in $T$. daintreei, and the wider (5-25 $\mathrm{mm}$, mostly 10-22 mm) Clent Hills specimens into T. thomsoniana. Their use of $T$. daintreei instead of $T$. spatulata was apparently due to the linking of the later with the Pentoxylales, which they regarded as circumspect for the New Zealand material. However, this ought to be irrelevant for purely impres- sion material. Their use of $T$. thomsoniana for the Clent Hills material follows Arber (1917). However, there are not clear morphological differences between the species described by Blaschke and Grant-Mackie (1976), and they probably could not be distinguished if they were found together.

As per Arber (1917), the most widespread Catlins Taeniopteris is referable to $T$. daintreei, 
whereas in the taxonomic scheme of Blaschke and Grant-Mackie (1976), a simple interpretation could place it into a broadly defined $T$. thomsoniana.

However, Taeniopteris spatulata has priority and is used in the present work. Taeniopteris vittata (Brongniart, 1828) is an even older name, but is ignored here as a Northern Hemisphere species. Person and Delevoryas (1982) and Rees and Cleal (2004) warned that Taeniopteris can exhibit a very broad range in size and were unimpressed with size as a criterion to distinguish species. The later maintained there was a gradation of Taeniopteris width in their Antarctic material from 9.5 up to 100 $\mathrm{mm}$ wide (although they did recognise two forms). This very large range of width encompasses the largest New Zealand Taeniopteris. Some early authors (e.g., Schimper, 1869; Feistmantel, 1877) placed relatively large leaves in Macrotaeniopteris. However, Arber $(1905,1917)$ maintained that size and shape alone were not sufficient to distinguish this (and other Taeniopteris-like taxa) and kept them all in Taeniopteris. Harris (1932) reserved Macrotaeniopteris for large leaves that had cycadean stomata. Hector (1886) figured a Macrotaeniopteris lata from Mataura Falls, but without a scale. The specimen was seen by Arber (1917) who noted the width as $66 \mathrm{~mm}$, with about 10 , mostly simple veins, per $10 \mathrm{~mm}$ of length. He placed this specimen, along with other material about $80 \mathrm{~mm}$ wide from Mataura, in T. crassinervis. Gupta's (1986) review of $T$. crassinervis included Arber's (1917) material in synonomy. He regarded $T$. crassinervis as most closely resembling $T$. lata Oldham (Oldham and Morris, 1863) in terms of size and shape, but gave three characters of the veins to distinguish them. A fragment with a width of about $100 \mathrm{~mm}$ from the Drumduan Group of Nelson was illustrated by Johnston et al. (1987) as $T$. cf. $T$ crassinervis. The largest Taeniopteris specimens found in the current study are two superimposed leaves from Curio Bay that are about $58 \mathrm{~mm}$ wide. My personal preference is to continue to draw attention to these larger forms by recording them as $T$. crassinervis but recognising that they may simply be the extremes of $T$. daintreei/T. spatulata.

At the opposite end of the width scale, the Waikawa Syncline localities are dominated by a remarkably narrow Taeniopteris. It is often found as overlapping masses on bedding in massive sandstone boulders, making it both difficult to collect and poorly preserved. The widths range from about $2.5-4.0 \mathrm{~mm}$, that is, comparable to only the very narrowest Taeniopteris widths cited by Blaschke and Grant-Mackie (1976), White (1981), and Rees and Cleal (2004) and also to "linear, needle-like" specimens in McLoughlin and Drinnan (1995, fig. $4 \mathrm{E})$. The existence of this very thin morphology in a restricted stratigraphic range has clear stratigraphic and perhaps climatic/edaphic potential. However, here is no clear taxonomic precedent that appears to apply, and for the present, an informal name, $T$. sp. 'narrow' is applied.

\section{Taenopteris spatulata McLelland, 1850 Figures 14.1, 15}

Material. Blue Cod Bay: LX0667, Boat Harbour: LX2068, LX2069, Curio Bay: LX1227, LX1228, LX1233, LX1234, LX1236, LX1237, LX1240-1246, LX1248-1252, LX1277, LX1278, Little Beach-01: LX1059, LX1254-1257, LX1259-1270, LX12721274, LX1276, LX0831, LX1082, LX1097-1099, LX1106, LX1108-1110, LX1112-1128, LX12171225, Little Beach-03: LX1020, Otara-8: LX2363, Otara-34: LX1194, The Chasm: LX0662, LX1177, LX1178, LX1179.

Description. Leaves strap-like, margins entire, gradually increasing in width from the base, margins parallel in the central portion and converging rapidly to an acute apex. Veins dichotomising once, usually at apparently random points between midrib and the margin. Rarely dichotomising and anastomosing again. Mostly 11-22 veins per 10 $\mathrm{mm}$ of midrib (but one specimen has c. 50).

Taeniopteris crassinervis (Feistmantel) Walkom, 1917

Figure 14.2

1877 Taeniopteris crassinervis Feistmantel, p. 102, pl. 38, figs. 1, 2, 2a, 2b.

1886 Macrotaeniopteris lata Hector, p. 66, fig. 30A (4).

1917 Taeniopteris crassinervis (Feistmantel); Arber, p. 45 , pl. 9 , fig. 4 , pl. 10, figs. 1-3, 5 .

1986 Taeniopteris crassinervis (Feistmantel) Walkom; Gupta, p. 195, figs. 2, 3.

Material. Curio Bay: LX2365.

Description. Leaves presumed strap-like, with entire margins, length probably $>200 \mathrm{~mm}$, width c. $58 \mathrm{~mm}$, midrib c. $2.0 \mathrm{~mm}$ wide, lateral veins at a high angle $\left(\mathrm{c} .80^{\circ}\right)$ to the midrib, $10-13$ per $10 \mathrm{~mm}$ of midrib, dichotomising within the lamina, with vein density increasing to c.18 per $10 \mathrm{~mm}$ in mid-lamina.

Taeniopteris sp. 'narrow' Figure 14.3

Material. Little Bay-01: LX1059, LX1254, LX1261, Little Bay-03: LX2365, LX1020. 

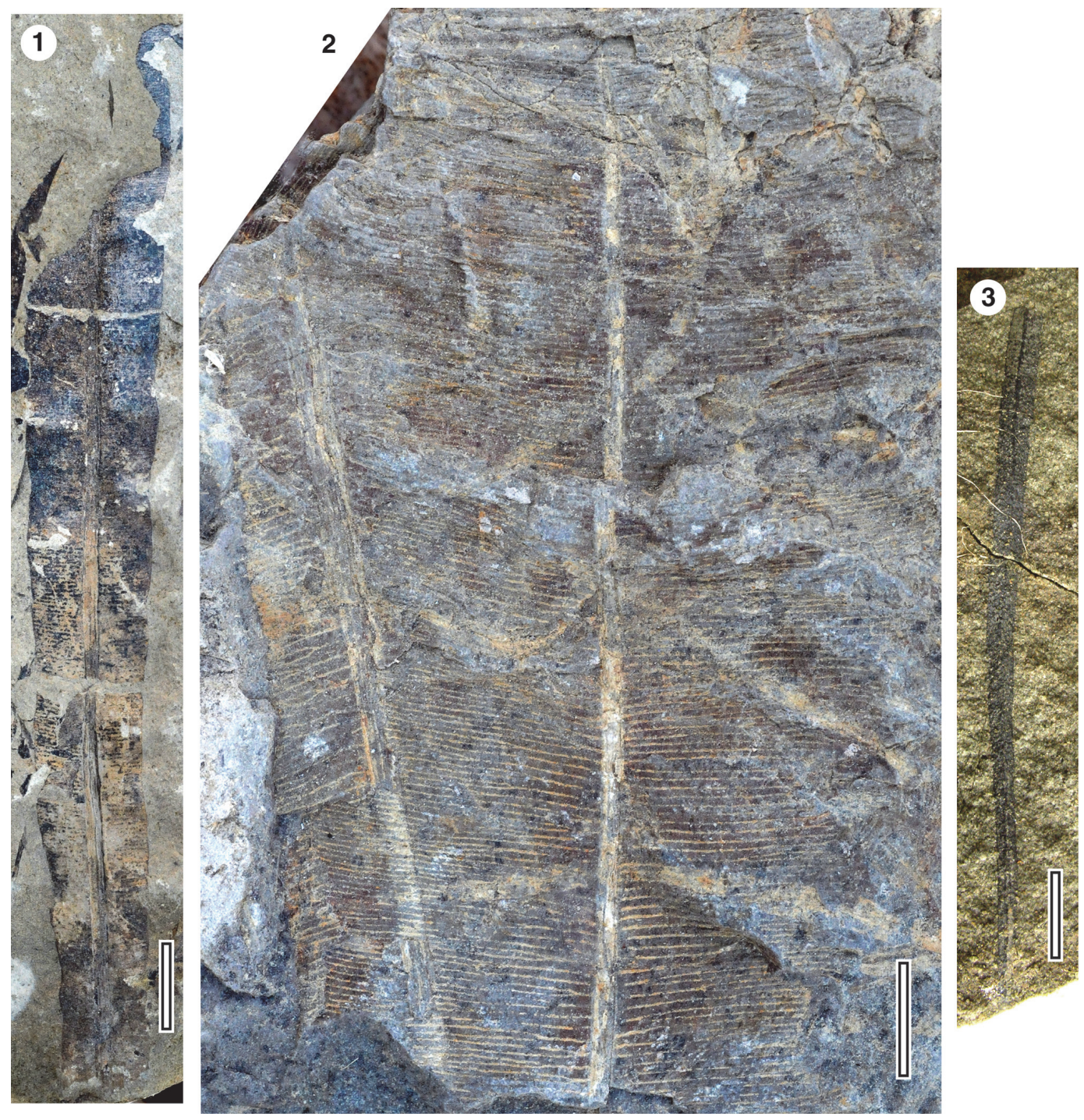

FIGURE 14. Taeniopteris leaves. 1. Taenopteris spatulata, LX1097, Curio Bay; 2. Taeniopteris crassinervis, LX2365, Curio Bay; 3. Taeniopteris sp. 'narrow', LX2365, Little Bay-03. All scale bars equal $10 \mathrm{~mm}$.

Description. Leaves elongate, with parallel, entire margins, length probably $>80 \mathrm{~mm}$, width typically c. $2.5-4.0 \mathrm{~mm}$, midrib $0.4 \mathrm{~mm}$ wide, lateral veins at high angle to midrib, but mostly unclear.

Class PINOPSIDA sensu Ruggiero et al., 2015

Remarks. In the absence of cuticle, placing coniferous foliage into taxa is a tenuous activity. The conifer foliage known from the Catlins Coast falls into at least four of the form-genera that were clarified by Harris (1969b). In the present study these include one that has elongate, single-veined leaves twisted into dorsi-ventral plane (i.e., distichous) placed into Elatocladus, one with broader leaves, multi-veined leaves placed into Podozamites, and one with small, scale-like leaves, placed in Pagiophyllum. In addition, Arber (1917, pl. 13, figs.
$8,10)$ figured shoots with the very short leaves of a typical Brachyphyllum.

Genus ELATOCLADUS Halle emend. Harris, 1979 Elatocladus confertus (Oldham and Morris) Halle, 1913

Figure 16

1886 Taxites matai Hector, fig. 30 (5).

1913 Palyssia conferta Arber, p. 346, pl. 8, fig. 5.

1913 Elatocladus conferta Halle, pl. 8, figs. 26-40.

1917 Elatocladus confertus (Oldham and Morris) Halle; Arber, p. 58, pl. 1, figs. 1, 3, pl. 6, fig. 4, pl. 8 , fig. 6.

1989 Elatocladus confertus (Oldham and Morris) Halle; Gee, p. 201, pl. 8, fig. 75.

2004 Elatocladus confertus (Oldham and Morris) Halle; Rees and Cleal, pl. 18, figs. 5, 6. 

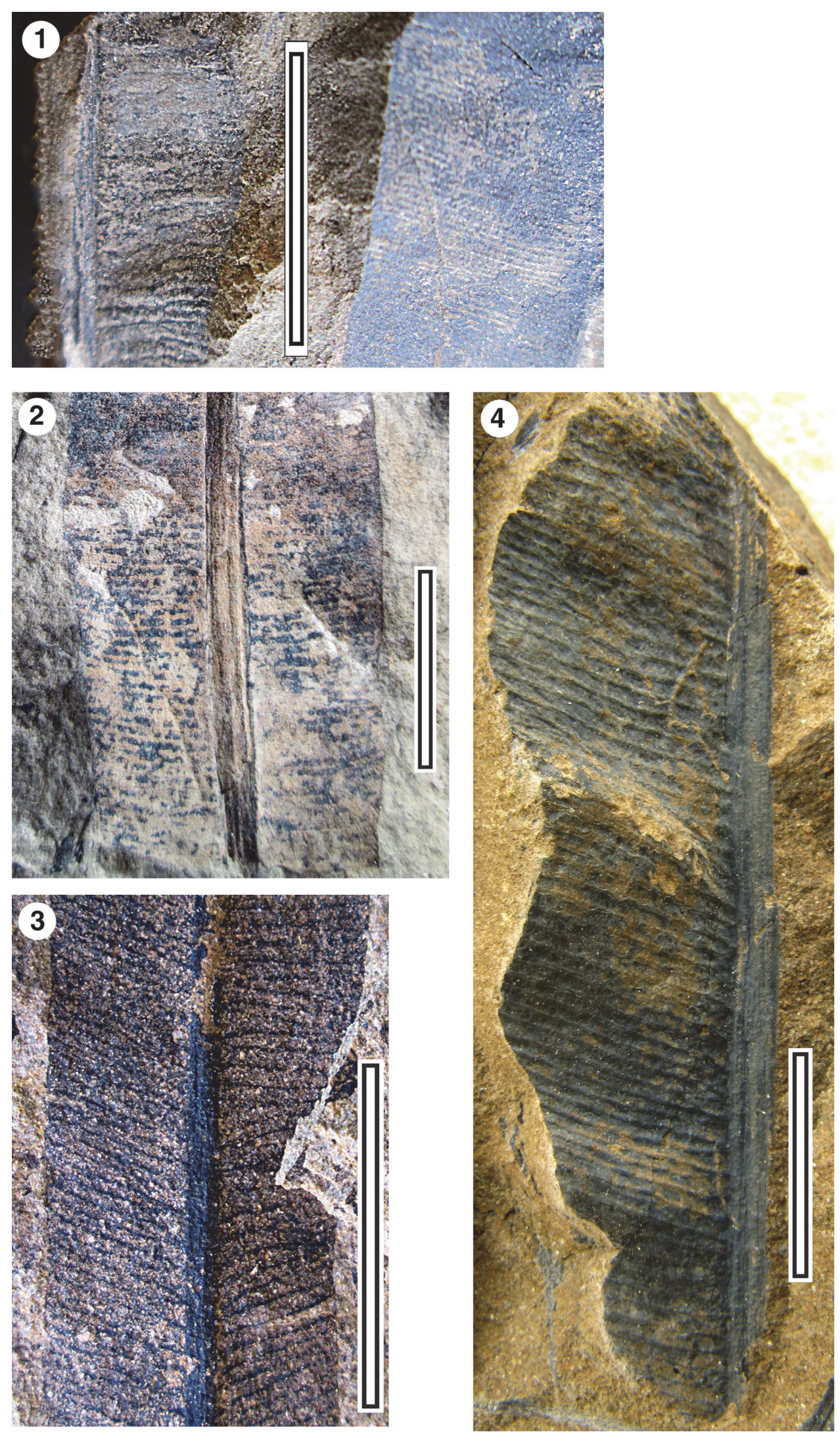

FIGURE 15. Taeniopteris spatulata details. 1. LX1218, Curio Bay; 2. LX1097, Curio Bay; 3. LX1277, Curio Bay; 4. LX1241, Curio Bay. All scale bars equal $10 \mathrm{~mm}$. 

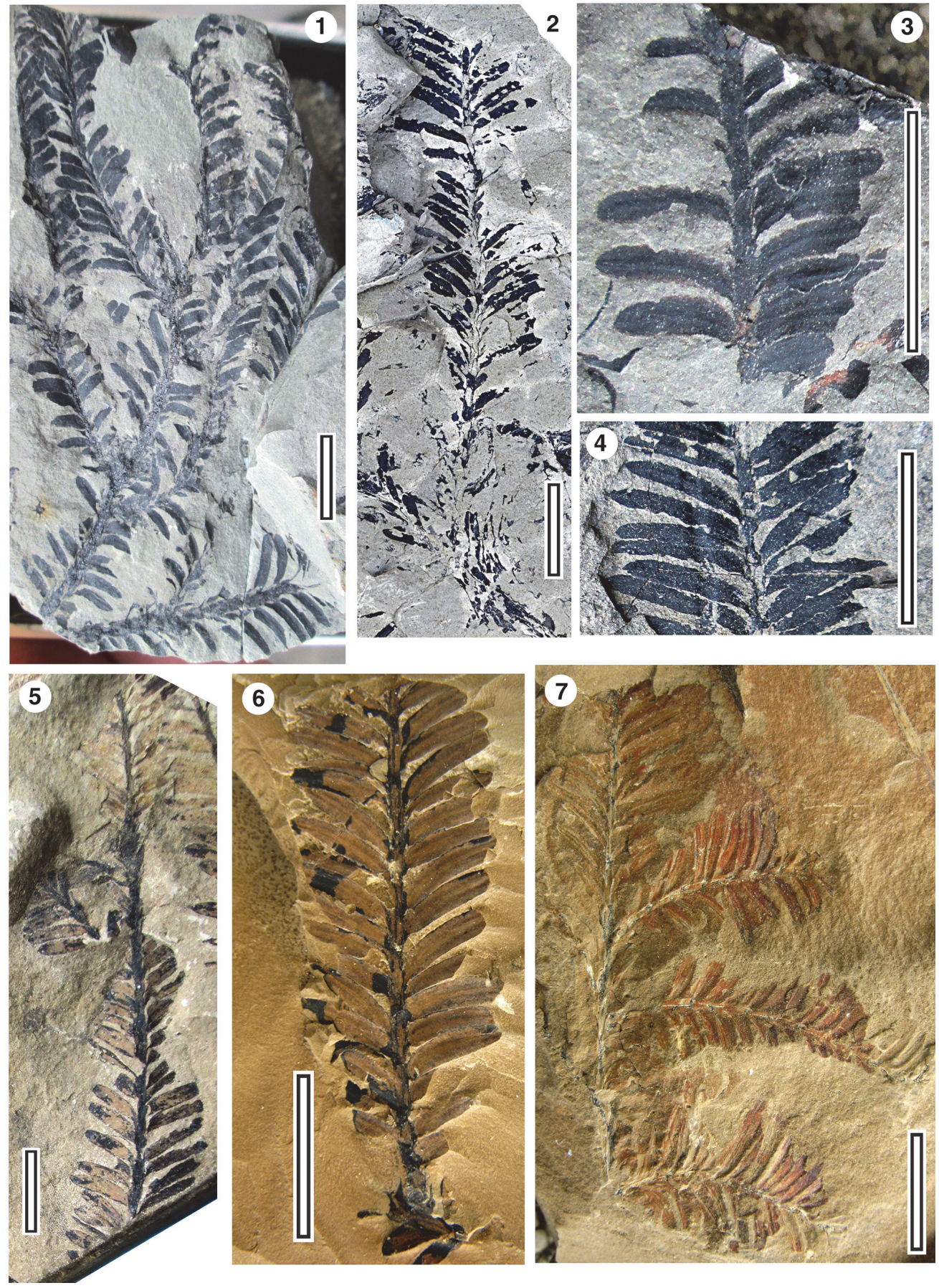

FIGURE 16. Elatocladus confertus 1. LX1060, Little Bay-01; 2. LX0674, Little Bay-01; 3. LX1050, Little Bay-01; 4. LX1057, Little Bay-01; 5. LX1107, Curio Bay; 6. LX1147, Blue Cod Bay; 7. LX1090, Curio Bay. All scale bars equal 10 $\mathrm{mm}$.

Material. Blue Cod Bay: LX0678, LX1147, LX1148, Curio Bay: LX1090, LX1102, LX1107, LX1169, Little Beach-01: LX0677, LX1050, LX1053, LX1055, LX1057, LX1058, LX1060, Otara-21: Noted in field, Otara-34: LX0686, Otara-31: LX0687, Otara-32: LX0694, Otara-33: LX0713, The Chasm: LX0661 LX1175, LX1176.
Description. Branching shoots $>80 \mathrm{~mm}$ long, with spirally inserted leaves on 1-2 mm diameter stem, distichously flattened. Around 6-8 leaves per 10 $\mathrm{mm}$ of stem, margins of adjacent leaves touching, or less than $0.5 \mathrm{~mm}$ apart. Leaves $6-9 \mathrm{~mm}$ long, 1.2-1.7 $\mathrm{mm}$ wide, bifacially flattened, falcate (reflexed, with mid portion of leaf arching apically), 
very elongate ovate, or with parallel margins in the middle, apices acute to rounded, base narrowed to a short false petiole, decurrent on stem, univeined, with vein running to apex.

Remarks. This is the most widespread conifer foliage type of the Catlins Coast Jurassic. Gee pointed out that Elatocladus confertus has reflexed leaves, and that this is a "fairly consistent character" to distinguish E. confertus from other Elatocladus species. Gee (1989), in her work on the Hope Bay material, clarified some of the characters present in these, or similar forms, and provided a key. This provides a basis to confirm the older New Zealand identifications and perhaps see if new species are present. One has thin, straight, narrow leaves, placed into $E$. planus. On the basis of epidermal information Townrow (1967) described a new taxon, Mataia podocarpoides, with affinities to Podocarpaceae, for a range of $E$. confertus material (the extant New Zealand conifer Prumnopitys spicata, Podocarpaceae, with Maori name 'matai', has similar foliage). The type locality was nominated as the Jurassic Clent Hills. However, there is no cuticular preservation there, and epidermal details come from material in the Upper Cretaceous strata in the Malvern Hills, New Zealand and from the Jurassic Walloon Coal Measures in Queensland, Australia (Note the error in Pole, 2009, where the cuticle was stated to come from the Clent Hills). The Catlins material may well be M. podocarpoides, but Mataia should be restricted to material with epidermal details. The $E$. confertus morphology has clearly been produced by various taxa (Frenguelli, 1949; Rao, 1964; Bose et al., 1982) and Podocarpaceae has been suggested as the affinity. In the Catlins Jurassic, given the common occurrence of permineralised wood with a structure consistent with Podocarpaceae (Crié, 1889; Arber, 1917; Edwards, 1934) and the common occurrence of broadly podocarpaceous pollen (Thorn, 2001; Raine et al. 2011) Podocarpaceae would seem likely. Edwards (1934) hinted at Elatocladus foliage being attached to a Palissya, a reproductive structure seeming more certainly coniferous, but with still unclear family affinities (Pattemore and Rozefelds, 2019, see below). On these grounds, the affinities of $E$. confertus remain open, and it is not placed here into any family here.

\section{Elatocladus sp. A \\ Figure 17.1-4}

Material. Little Beach-01: LX1049, LX1054, LX1056, LX1061, LX1129, LX1131, LX1132, LX1133, LX1149, LX1150, LX1154, LX1157, LX1159.
Description. Detached shoots, up to at least 95 $\mathrm{mm}$ long, c. $1 \mathrm{~mm}$ diameter, with acroscopicallycurving, single-veined, bilaterally flattened leaves, 6-12 mm long, 0.7-1.3 mm wide, strongly decurrent basal margin, spaced c. 2-3 mm along stem.

Remarks. Distinct in having acroscopically-curving leaves that are interpreted as bilaterally flattened. The short length of these leaves, and the branching, makes them apparently distinct from Bellarinea richardsii. However, they both occur in the same locality, and future collecting should seek to clarify that they are not an extreme morphology of the same taxon. The bilateral flattening is similar to the Cretaceous cheirolepid conifer Otwayia (Pole, 2000; Tosolini et al., 2015), although the falcate leaves are different. Palynology has established the existence of Cheirolepidiaceae in the Murihiku Group Jurassic (Raine and Pole, 1988; de Jersey and Raine, 1990), but the corresponding foliage in New Zealand is as yet unknown (it could be represented by some Pagiophyllum, cf. Tosolini et al., 2015).

\section{Elatocladus sp B \\ Figure 17.5}

?1917 Elatocladus sp. Arber, pl. 8, fig. 9.

Material. Blue Cod Bay: LX2077.

Description. Shoot with bifacially flattened, wellspaced (c. $3 \mathrm{~mm}$ ), opposite leaves, to at least c. 20 $\mathrm{mm}$ long, $3 \mathrm{~mm}$ wide, narrowing to a false petiole (c. $1 \mathrm{~mm}$ long) from c. $2 \mathrm{~mm}$ from the base, tapering towards the apex, single-veined.

Remarks. A single specimen is distinct in its relatively large, apparently opposite leaves, distinctly narrowed at the base to a false petiole.

Genus BELLARINEA Florin, 1952 emend.

Nagalingum Drinnan and McLoughlin, 2002

Bellarinea richardsii Nagalingum Drinnan and McLoughlin, 2002

Figure 18

1886? Taxites manawao Hector, fig. 30A (2).

1917 roots, Arber, pl. 10, fig. 4.

1934 Elatocladus plana (Feistmantel); Edwards, p. 103, pl. 5, fig. 3 .

2002 Bellarinea richardsii Nagalingum Drinnan and McLoughlin, fig. 40E in McLoughlin et al. (2002).

Material. Curio Bay: LX1239, Little Beach-01: LX0675, LX0676, LX1052, LX1130, LX1156, LX1271, LX1275.

Description. Detached shoots, c. $90 \mathrm{~mm}$ long, axis c. $1 \mathrm{~mm}$ diameter, with spirally inserted leaves, probably distichously flattened. Leaves linear, straight or slightly inwardly curved, very elongate, 

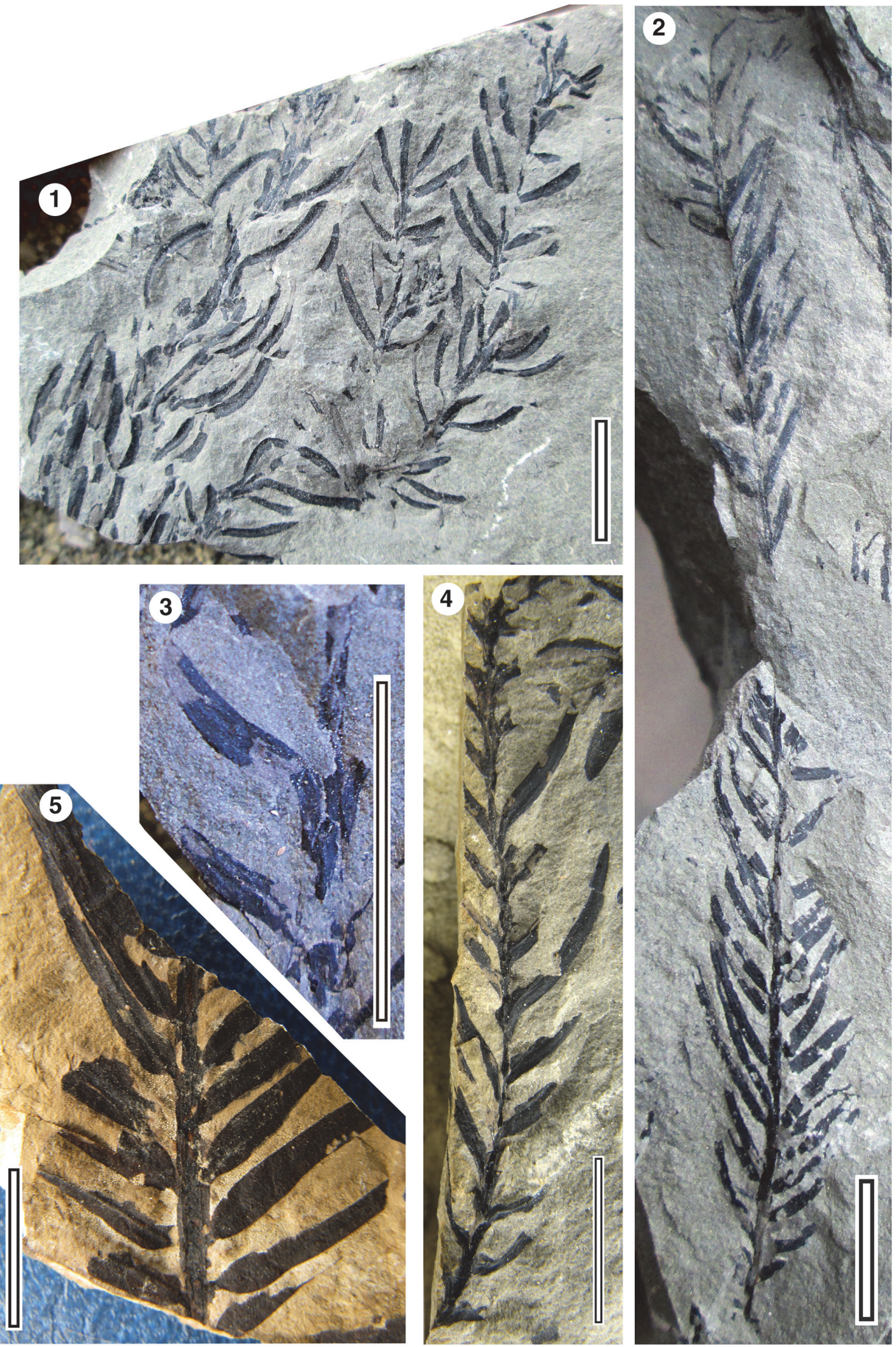

FIGURE 17. Elatocladus spp. 1. Elatocladus sp. A, LX1054, Little Bay-01; 2. Elatocladus sp. A, LX1061, Little Bay-01; 3. Elatocladus sp. A, LX1131, Little Bay-01; 4. Elatocladus sp. A, LX1159, Little Bay-01; 5. Elatocladus sp. B, LX2077, Blue Cod Bay. All scale bars equal $10 \mathrm{~mm}$. 

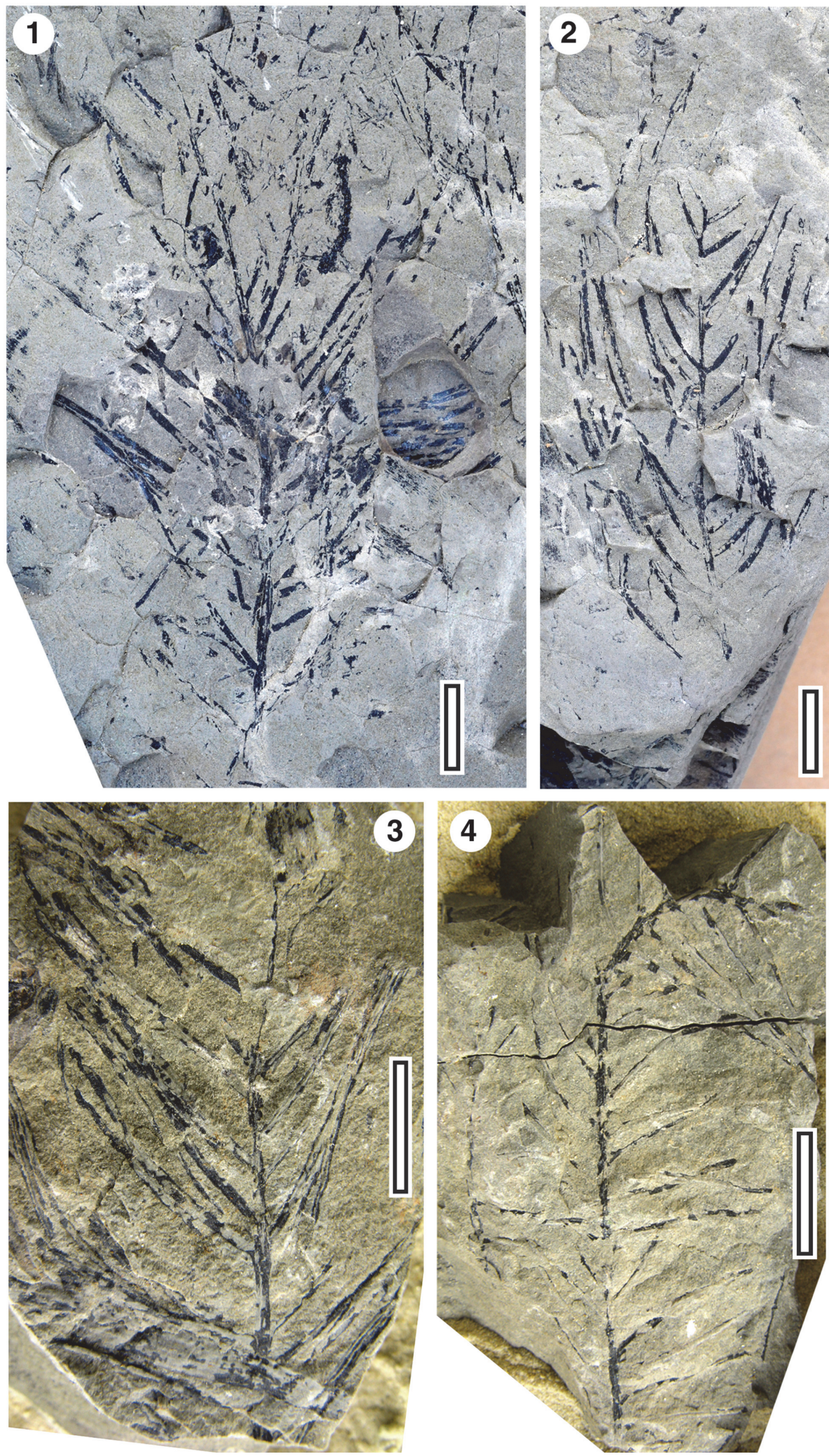

FIGURE 18. Bellarinea richardsii, all Little Bay-01. 1. LX0676; 2. LX0675; 3. LX1275; 4. LX1130. All scale bars equal $10 \mathrm{~mm}$. 
up to $34 \mathrm{~mm}$ long, $0.7-1.0 \mathrm{~mm}$ wide, well-spaced, typically 3-6 $\mathrm{mm}$ apart, not narrowed at the base, probably decurrent basally, perhaps slightly expanded apically.

Remarks. This material is similar to one of the specimens illustrated by McLoughlin et al. (2002, fig. 40E) and Nagalingum et al. (2005, fig. 2B) as Bellarinea richardsii. Both show the well-spaced, very elongate, inflexed leaves, attached to the axis with no sign of narrowing to a false petiole, and in some cases, an apical margin at the base that curves apically. This is a distinctive morphology and may indicate the material is conspecific. Florin's (1952) original concept of Bellarinea required epidermal information for identification. However, Nagalingum et al. (2005) emended the generic diagnosis to include the shoots being unbranched and, therefore, probably annually deciduous. This contrasted with typical Elatocladus that have branched shoots and rhythmic growth. This suggests it would be useful to recognise an additional conifer form genus to those of Harris $(1969,1979)$ with Elatocladus emended to cover branched shoots only (with the down-side that fragments would be harder to deal with). Despite the lack of epidermal information in the Catlins material, Bel- larinea richardsii is used here to emphasise the morphological similarity with the Victorian material.

\section{Genus PODOZAMITES Braun, 1843 \\ Podozamites gracilis Arber, 1917 \\ Figure 19}

1917 Podozamites gracilis Arber, p. 54, figs. 11, 12.

Material. Curio Bay: LX1084, LX109, Little Beach04: LX1012.

Description. Shoots $>70 \mathrm{~mm}$ long with alternately inserted leaves, c. 5-19 mm apart, possibly loosely distichously flattened. Leaves bifacially flattened, 33-46 mm long, 2-6 mm wide, bases narrowly acute, apices acute. Venation indistinct, but apparently parallel, with 3 veins in the narrowest leaves, to possibly 10 veins across the widest.

Remarks. Arber (1917) described Podozamites gracilis from Curio Bay. As the name suggests, the leaves were remarkably narrow, $4-5 \mathrm{~mm}$ wide, and in this width, there were 5-7 parallel veins. This is one of the narrowest Podozamites species known, being distinctly smaller than the typical TriassicJurassic Podozamites of the Northern Hemisphere (e.g., Pole et al., 2016). Some of the smallest species do overlap. Podozamites lanceolatus illustrated from the Late Triassic of China ( $\mathrm{Li}, 1964$, fig. 20.3) comes close.
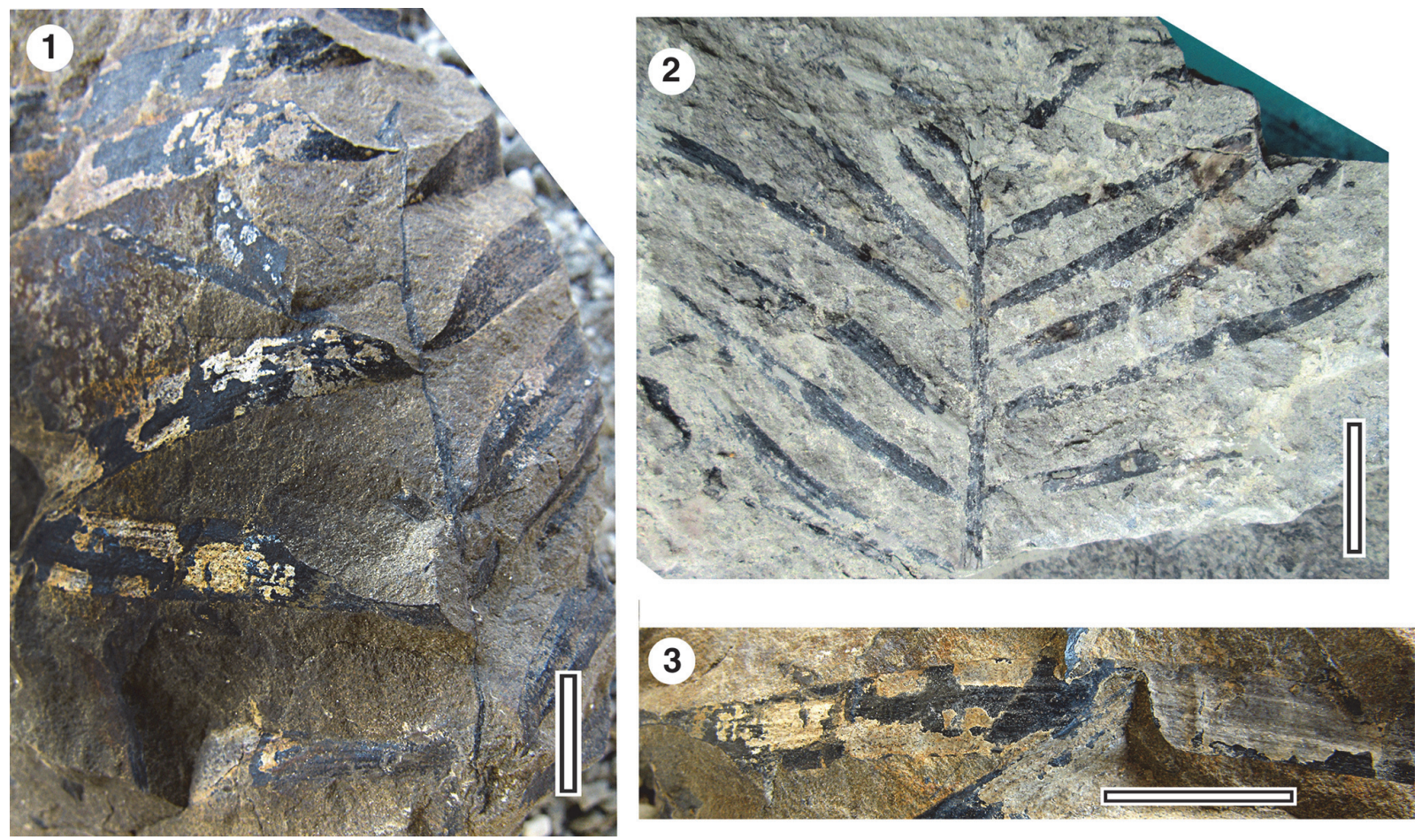

FIGURE 19. Podozamites gracilis 1. LX1084, Curio Bay; 2. LX1012, Little-03; 3. LX1084, Curio Bay. All scale bars equal $10 \mathrm{~mm}$. 



FIGURE 20. Pagiophyllum sp. 1. LX1142, Owaka; 2. LX1016, Little-03; 3. LX1023, Little-03. All scale bars equal 10 $\mathrm{mm}$.

\section{Genus PAGIOPHYLLUM Heer, 1881 Pagiophyllum sp.}

Figure 20

Material. Owaka: LX0663, LX0990, LX0991, LX0996, LX0997, LX1000, LX1006, LX1011, LX1141-1143, LX1163, LX1164, LX1167, LX1168, Little Beach-04: LX1015, 1016, 1017, 1019, 1023, 1030.

Description. Shoots c. $2-2.5 \mathrm{~mm}$ diameter, with spirally-inserted scale-like leaves $2-3 \mathrm{~mm}$ long, c. $0.5 \mathrm{~mm}$ wide.

\section{Genus PITYOPHYLLUM Nathorst, 1897 Pityophyllum sp. \\ Figure 21}

Material. Slope Pt-01, LX684, LX685.

Description. Extremely elongate leaves, c. $2 \mathrm{~mm}$ wide, but up to over $70 \mathrm{~mm}$ long, with either a midrib taking up about a third of the lamina width, or $\mathrm{c}$. 3 longitudinal veins. Typically straight, sometimes falctae.

Remarks. These leaves are sometimes found in masses. If a form genus name is needed, Pityophyllum may be the most appropriate (Seward, 1919). They are also comparable to some specimens which have been published as detached microphylls of Isoetites (for example, McLoughlin et al., 2002, fig. 7E). This should be given serious consideration. However, until more positive evidence of them being Isoetites turns up, Pityophyllum is a 'safer' term. They could be seen as an extremely small Taeniopteris, although there is no sign of lateral veins, or perhaps individual Bellarinea leaves, although no intact shoots have been noted in association. Attention is also drawn to some that lie close to Palissya cones (see below) and may indicate the foliage of that taxon.

\section{Cones}

ARAUCARITES Presl in Sternberg, 1838

Araucarites cf. cutchensis Feistmantel, 1877

Figure 22

Material. Little Beach-02: LX2364, LX2367.

Description. Ovulate scale, cuneate, $13-20 \mathrm{~mm}$ long, 22-24 mm wide, maximum width c. 50-70\% of distance from base to apex. Lateral margins straight, distal margin curved. Ratio of scale length to maximum width 0.5-0.8. Seed scar wedgeshaped, located in central portion of scale, margin indistinct, but up to c. $3.5 \mathrm{~mm}$ wide,

Remarks. The specimens are compared with the widely-reported taxon Araucarites cutchensis.

The genus was discussed by Cleel and Rees (2003) who remarked that "some show ovuliferousscales with a single ovule and a free distal ligule, which suggest that they belong to the Araucariaceae," and although some authors place them in 


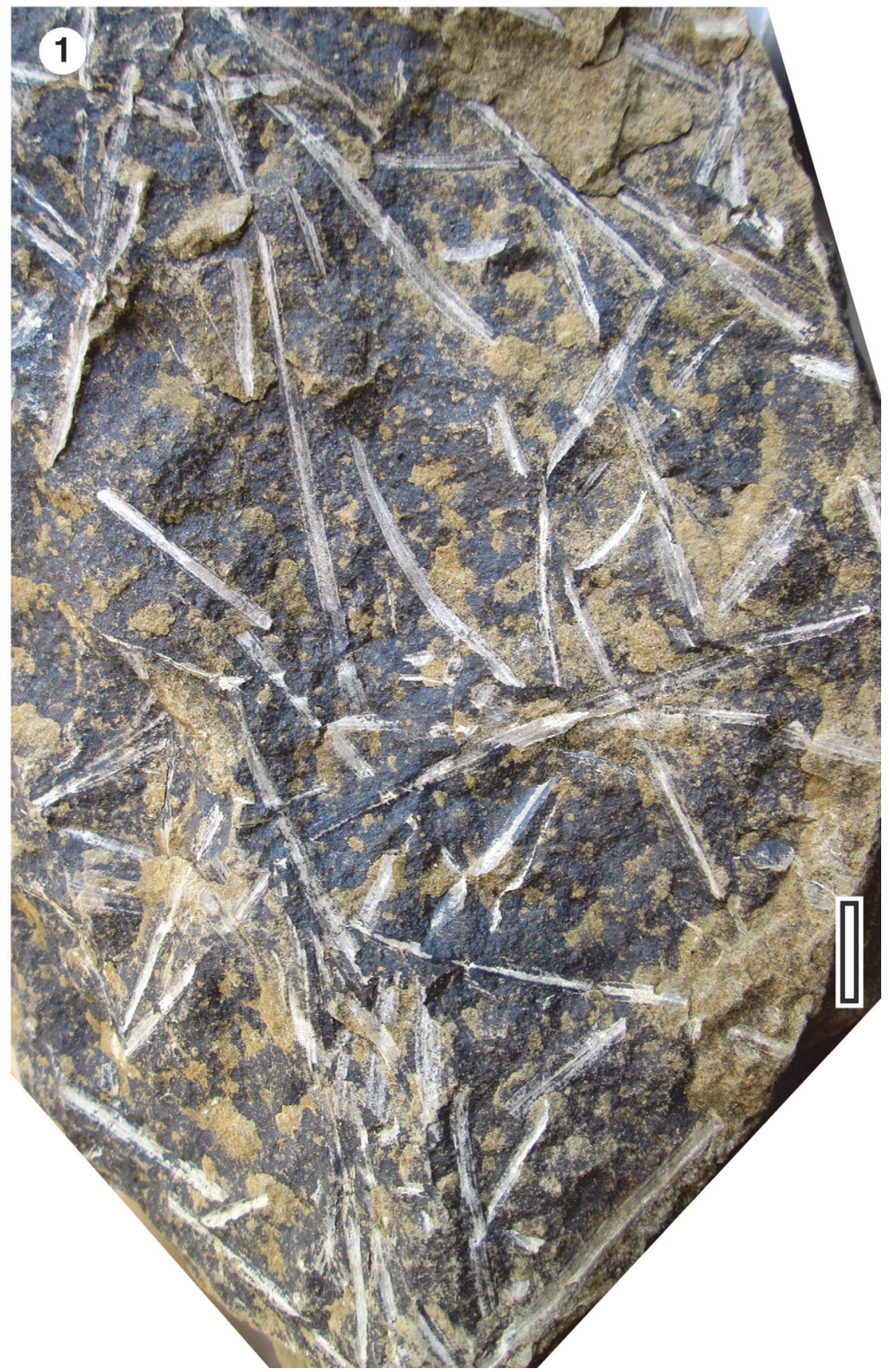

FIGURE 21. Pityophyllum sp. 1. LX656, Slope-01 (scale bar equal $10 \mathrm{~mm}$ ).

Araucaria, they preferred to assign isolated organs to Araucarites. This follows Rees and Cleal (2004) in assigning similar specimens from Hope Bay, Antarctica to this genus. They placed their material in Araucariaceae, whereas Gee (1989) regarded Hope Bay material as Araucaria. In the absence of cuticular details of the Catlins Coast foliage to confirm the presence of Araucaria, the more conservative Araucarites is preferred here. A ligule is not apparent on the Catlins material, although this may have been broken off. Edwards (1934) described, but did not figure, an araucarian cone scale from Curio Bay as Araucarites grandis Walkom. His specimen was $45 \mathrm{~mm}$ long by "a little under" 30 $\mathrm{mm}$ wide.

PALISSYA Endlicher, 1847

Palissya batrumi Edwards, 1934, emend. 

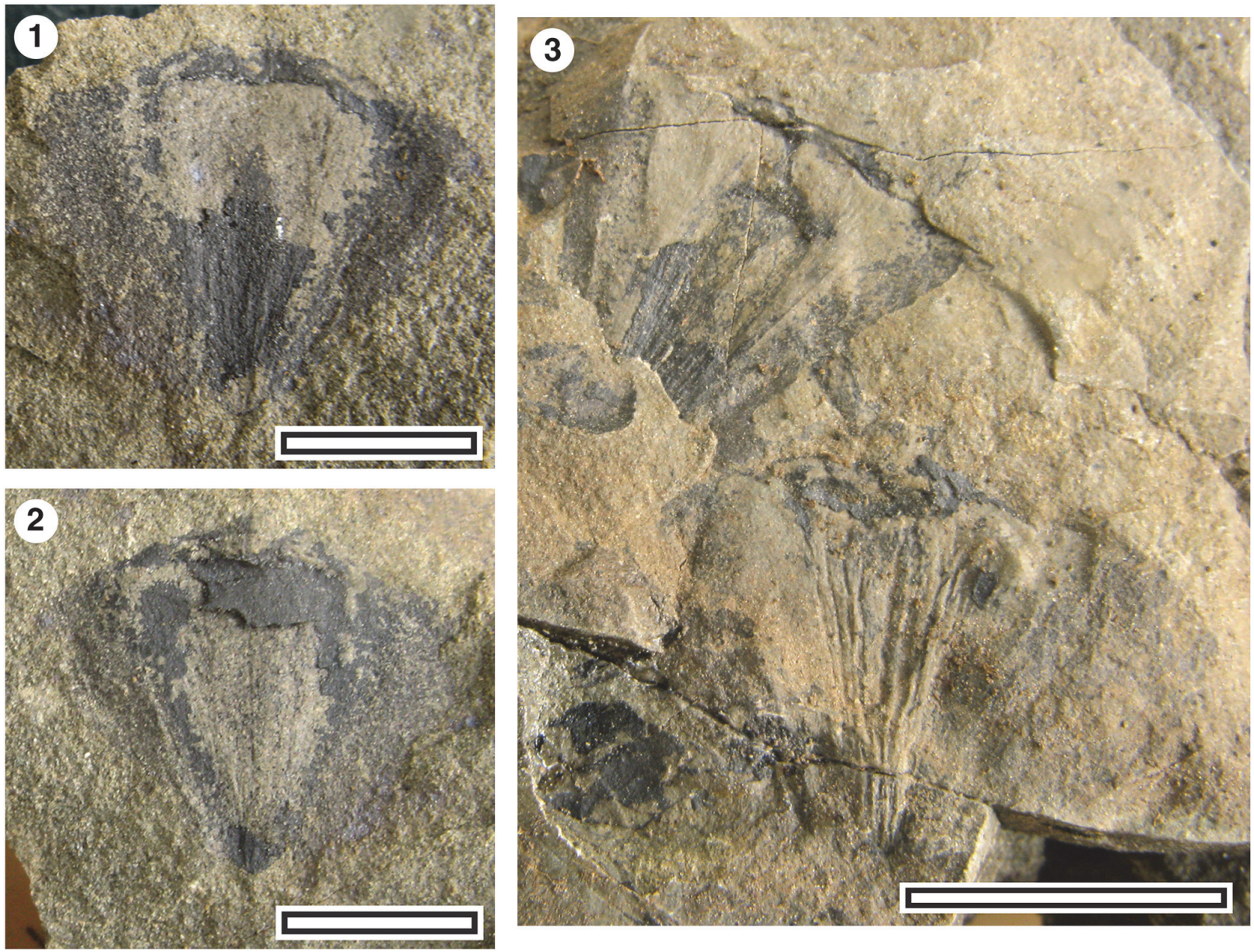

FIGURE 22. Araucarites cutchensis 1. Ovulate scale (LX2364); 2. Counterpart of previous (LX2364); 3. Two cone scales (LX2367). All Little-02, scale bars equal $10 \mathrm{~mm}$.

Pattemore and Rozefelds, 2019

Figure 23

1917 Stachyotaxus (?) sp., Arber, p. 61, pl. 13, fig. 7.

1921/ Stachyotaxus cf. S. elegans Nath.; Bartrum, p. 258.

1934 Palissya batrumi Edwards, p. 100, pl. 5, figs. 5, 6.

2019 Palissya batrumi Pattemore and Rozefelds, $p$. 197, fig. 10.

Material. Boat Harbour: LX2071, Curio Bay: LX1096, 1103, Little Beach-01: LX0721, Otara-20: LX2238, LX2239, Otara-22: LX2178.

Description. Cones, at least $90 \mathrm{~mm}$ long, 10-17 $\mathrm{mm}$ diameter. Cone axis $2-3 \mathrm{~mm}$ diameter, bearing helically-arranged, rhomboid bract/scales, 3-5 mm wide, 5-7 mm long, sub-perpendicular to the axis, then reflexed strongly apically. Each bract/scale with about four pairs of ovule/scale units on the adaxial surface, placed oppositely, along the bract/ scale midline.
Remarks. Distinctive elongate cones have been placed in Palissya, a genus established on material from the Jurassic of Europe. Figure 23.1 exhibits the external morphology, other specimens are split, or weathered to reveal internal detail, In Figure 23.2, the apical portion has been split along the central axis, while in Figure 23.4, the external surface has been removed to clearly show the paired ovule/scale units. On the adaxial surface 0 .

Palissya was initially assumed to represent ovulate cones, probably coniferous. In fact, Edwards (1934) claimed to have found a Palissya attached to what seemed to be an Elatocladus conifer shoot. However, Parris et al. (1995) reviewed the New Zealand and Australian examples of Palissya (including material from Black Bay) and expressed doubt that they were from conifers. Schweitzer and Kirchner (1996) then made a case for Palissya being microsporangiate. Subsequently, some of the Australian Palissya were placed in Knezourocarpon (Pattemore, 2000) in 

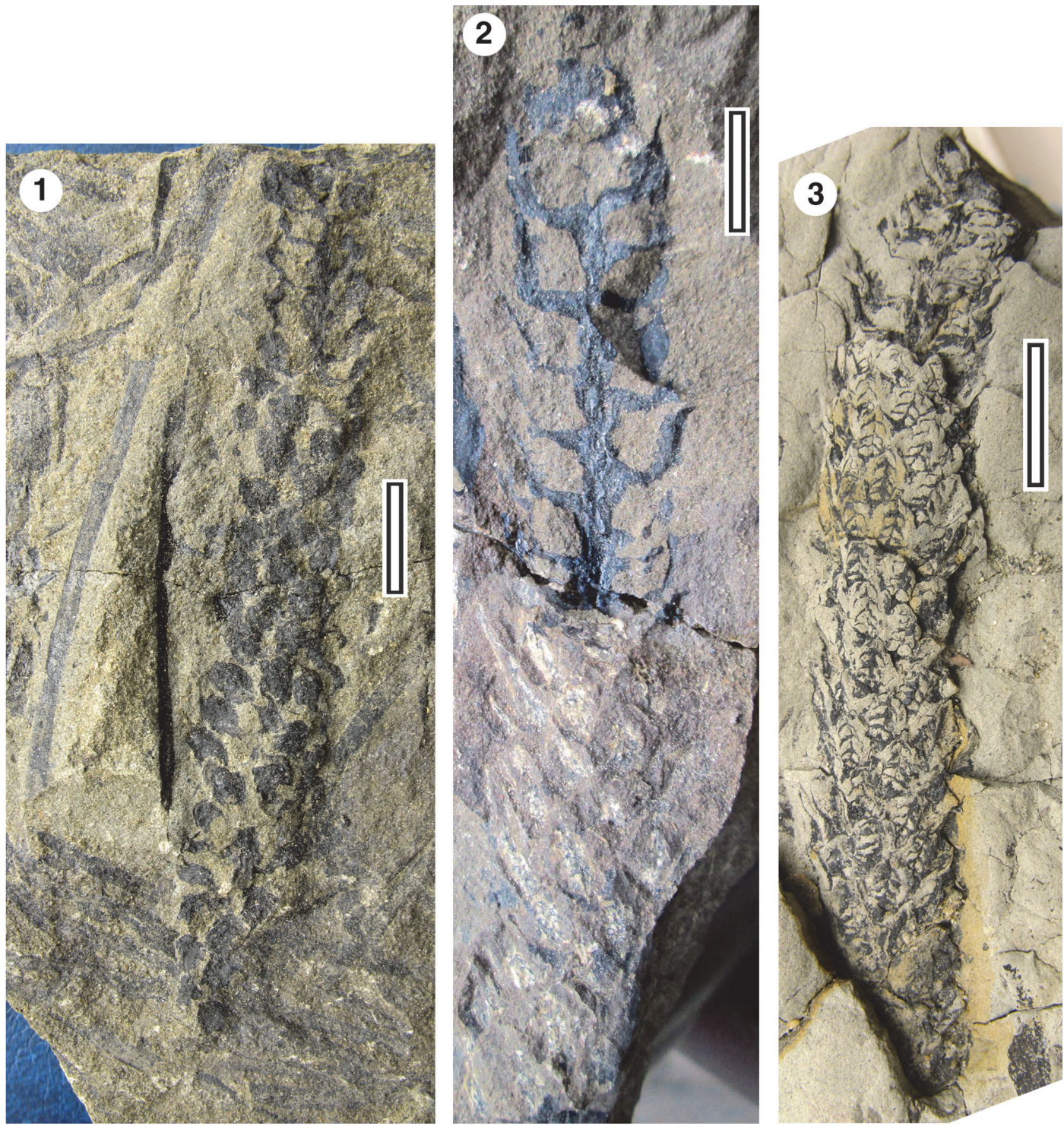

FIGURE 23. Palissya batrumi 1. Specimen showing external morphology, LX721, Little Beach (Note adjacent Pityophyllum); 2. Specimen with apical part split longitudinally, revealing the axis, LX1096, Curio Bay.; 3. Specimen weathered to reveal the adaxial surface with paired ovule/scale units, LX2238, Otara-20. All scale bars equal $10 \mathrm{~mm}$.

Knezourocarponaceae, possibly with ginkgoalean or pteridospermous affinity. They concluded that other Australian and the New Zealand taxa, were probably new genera in the Knezourocarponaceae. Pattemore et al. (2014) concluded that all Australasian Palissya were distinct from the original Northern Hemisphere concept of the taxon. Most recently, Pattemore and Rozefelds (2019) emended the diagnosis of the New Zealand material, $P$. bartrumi, and emphasized a likely relationship within the conifers for the genus. Some comparison with extant Taxaceae and Podocarpaceae was noted.
In Antarctica, Palissya has been described from the Aptian of Snow Island, Antarctica (Cantrill, 2000), but has not been described from the Hope Bay or Botany localities (Gee, 1989; Rees and Cleal, 2004).

\section{DISCUSSION}

\section{Palaeolocation}

Contemporary global plate tectonic models place the New Zealand sector of Gondwana (i.e., the Western Province, Mortimer, 2004) in high latitudes c. $160 \mathrm{Ma}$ (e.g., Wright et al., 2013, 78-82 ${ }^{\circ}$ S, 
Seton et al., 2012, place Fiordland and the NW Nelson area at about $80-85^{\circ} \mathrm{S}$ ). However, the location of the Murihiku Terrane with respect to the Gondwanan foreland at the time is unclear. If, for example, it lay c. $600 \mathrm{~km}$ east of the current location of Brisbane at $160 \mathrm{Ma}$, its palaeolatitude was approximately on the Polar Circle (i.e., c. $66^{\circ}$, under both the Seton et al., 2012 and Wright et al., 2013 plate models), but conclusions based on marine fossils (Stevens, 1971, 1980) argue for a more mid-latitude position. In fact, the Catlins Coast flora is very similar to the middle or possibly late (Wainman et al., 2018) Jurassic Mutdapilly flora from the Walloon Coal Measures near Brisbane (McLoughlin and Drinnan, 1995, see below) which likely lay close to the Polar Circle (also based on the Seton et al., 2012 and Wright et al., 2013 plate models). However, Jurassic floral zones are likely to have been broad, and vegetation significantly to the north and south of the Walloon Coal Measures may have been equally similar. The presence of economically thick coal seams in the Walloon Jurassic, but the virtual lack of coal in the Catlins Jurassic might result from a broad difference in depositional environment, but it may also hint at a different palaeolatitude. The evidence remains unclear as to whether the Catlins Jurassic accumulated above or below the Polar Circle.

\section{Vegetation Ecology}

The distribution of the taxa by locality is summarised in Figure 24. The most widespread and commonest plants of the Catlins Coast Jurassic are Cladophlebis and Taeniopteris. These are locally abundant with Cladophlebis in particular covering bedding surfaces at some localities as a monospecific assemblage. Equisetum is more restricted, but where it does occur, tends to also form monospecific assemblages. With the exception of the Waikawa Syncline, the next most common taxon is the conifer Elatocladus, which can occur with both Cladophlebis and Taeniopteris. Other foliage taxa tend to be much less common.

Disturbance in the form of river avulsion events and volcanic eruptions are likely to have been relatively frequent. The abundance of Cladophlebis and Taeniopteris and infrequent conifers compared to Curio Bay may be a function of higher water tables, more disturbance, or both. Equisetum is not present within the Curio Bay forest beds but was reported from the Curio Bay-Haldane road cutting locality by Edwards (1934).

\section{Climate}

The evidence from fossil wood (Creber and Chaloner, 1985) clearly indicates an element of seasonality for the Catlins Jurassic, although exactly what contributed to this is less clear. Two of the fern taxa in the Catlins Jurassic help to very broadly constrain local temperatures. Osmundaceae are today mainly found in the tropics although mostly in the upland regions, but extend into temperate latitudes, such as Sweden. Their long history and widespread nature suggest they could be reliable indicators of climate, with the current distribution suggesting a preference for relatively cool temperatures without cold extremes. Dipteridaceae have long been considered as indicating relatively warm temperatures (Barnard, 1973; Corsin and Waterlot, 1979), with the single extant genus (Dipteris) confined to the lowland tropics. At least seven genera of Dipteridaceae are recognised Choo and Escapa, 2018), with Mesozoic global generic diversity peaking at five (in four morphological groups, Cantrill, 1995; see also Choo et al., 2016) and local diversity being highest in mid-low latitudes and in humid conditions. For example, in the late Triassic, China had five genera with many species (Zhou et al., 2015), but in the Early Cretaceous, as the region dried, the genera decreased to just Hausmannia and Dictyophyllum. The very high palaeolatitude $\left(>72^{\circ} \mathrm{N}\right)$ mid Cretaceous Grebenka Flora of Siberia has Hausmannia as the sole Dipteridaceae in conditions inferred to have been moist and frost-free (Spicer et al., 2002). In this case, the low diversity of Diperidaceae is likely to result from relatively cool temperatures. Hausmannia and Dictyophyllum thus appear to be the hardiest Dipteridaceae, and the (rare) presence of just these two in the Catlins Coast Jurassic is consistent with a relatively cool, but still frost-free conditions in the horizons they are found, consistent with a relatively high latitude position in a global greenhouse period. However, in the Jurassic-Early Cretaceous, Hausmannia only occurred in what were relatively northern latitudes of Australia (Gould, 1980; McLoughlin, 1996, McLoughlin and Drinnan, 1995; McLoughlin and Hill, 1996; McLoughlin and McNamara, 2001; Peyrot et al., 2019; Walkom, 1928; White, 1961), and argues against very high latitude.

Taeniopteris is generally thought to have had very thin leaves, and the leaves are often found in masses. These suggest a fast-growing leaf that was excised synchronously, i.e., deciduous. Including Taeniopteris, three of the Catlins Jurassic taxa have been suggested by other workers to have 


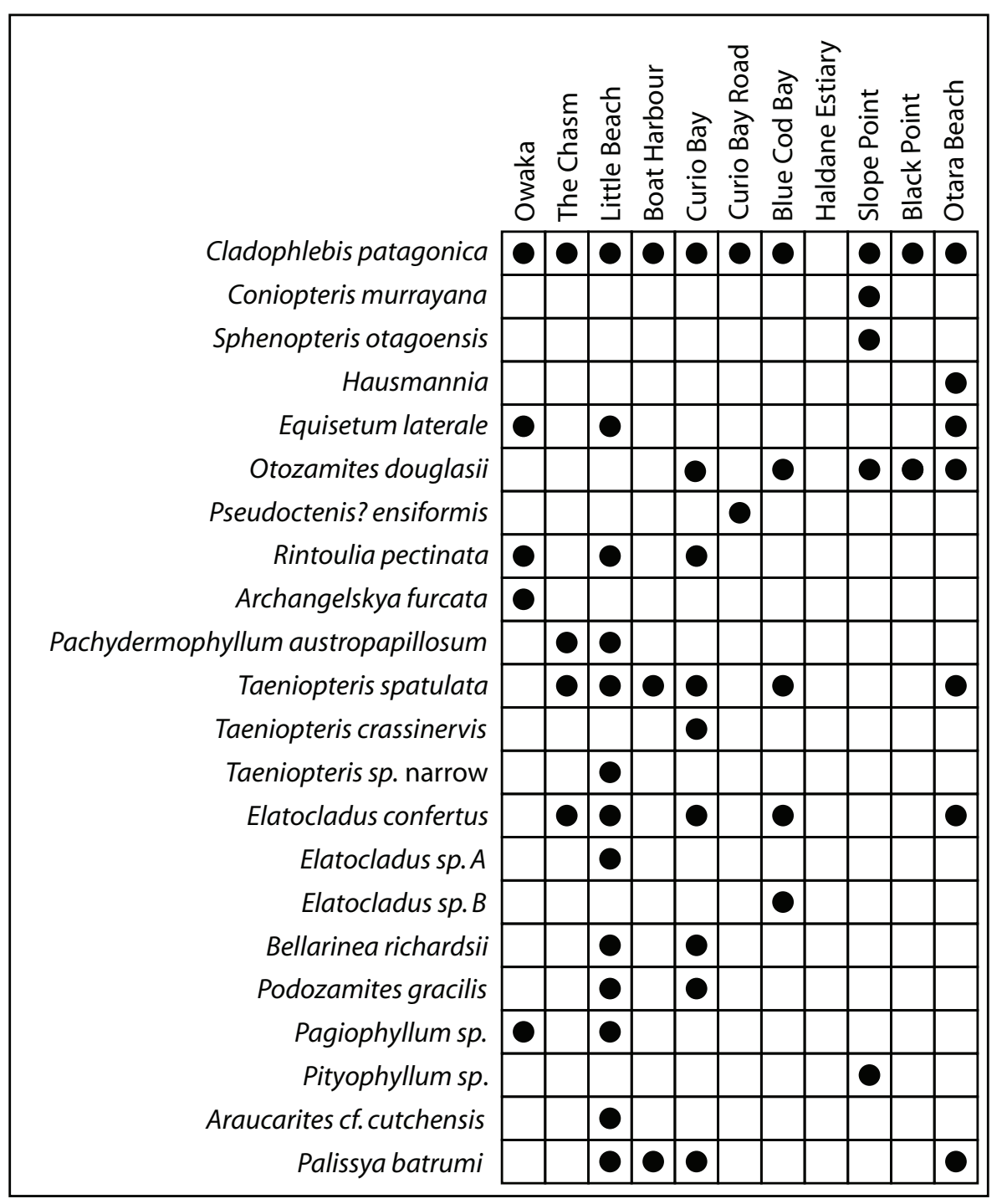

FIGURE 24. Summary chart of taxa distribution across the main localities and the total number of catalogued specimens.

been annually deciduous. A Victorian species of Rintoulia, R. variablis (Douglas) McLoughlin and Nagalingum (2002), was suggested to have been deciduous by McLoughlin et al. (2002) based on its typical occurrence in leaf mats. They also suggested the conifer Bellarinea richardsii Nagalingum et al. (2005) was deciduous based on its unbranched fossil shoots, in contrast to the branched Elatocladus conferta, which suggested an evergreen habit. The factors determining the balance between evergreen and deciduous taxa in vegetation is a complex subject. Suffice to say that (based on the contemporary situation), seasonality, such as winter cold, or a dry season, is implicated when vegetation is predominantly deciduous (clear growth-rings on Catlins Coast fossil wood is clear evidence of some sort of seasonality). Either or both factors could have been present in the Catlins Jurassic. On a local scale, ecological niche can be important. For example, in boreal forests today, deciduous and evergreen taxa can co-exist, but with the faster-growing deciduous trees occupying a post-fire niche. Based on charcoal, fire was clearly a factor in the Catlins Jurassic, and some fire-mediated vegetation distribution was likely.

New Zealand did not have the large-leaved and multi-veined Podozamites that are so typical of many Northern Hemisphere assemblages. Instead, the $P$. gracilis (Arber, 1917) that was present has leaves even smaller than those of some Jurassic Northern Hemisphere single-veined conifers, for example Storgaardia (Harris, 1935). The small leaf 
size of both $P$. gracilis and the other single-veined leaf conifers suggests a sub-optimal climate. In addition, the small pinnules of Otozamites douglasii are further evidence of relative coolness. A size gradient of Otozamites pinnules from large-small with increasing latitude (and presumed decreasing temperature) has been documented for the Australian Early Cretaceous (McLoughlin et al., 2002). Thus, leaf size also suggests relatively cool conditions in the Catlins Jurassic.

Some major plant groups, which are still notably absent from the Catlins Coast Jurassic record, might also help constrain climate belts. For example, the Ginkgoales are common in Triassic and Early Cretaceous floras of Australia, but, like New Zealand, they are notably absent from Jurassic floras of the Hope Bay (Gee, 1989; Rees and Cleal, 2004) and Australia (Turner et al., 2009). Likewise, macrofossils of the Caytoniales are represented in the eastern Australian Jurassic (Gould, 1975; Turner et al., 2009; Jansson et al., 2008) and the Antarctic Peninsula (Rees and Cleal, 2004) but have not yet been recorded from New Zealand. The Lycophytes have a relatively poor macrofossil record in the Australian Jurassic-Lower Cretaceous (Lower Jurassic, Queensland - Jansson et al., 2008; Middle Jurassic, Queensland - Rigby, 1978; Upper Jurassic, NSW - White, 1986; Lower Cretaceous, WA - Walkom, 1944; McLoughlin, 1996; McLoughlin and McNamara, 2001; Lower Cretaceous, South Australia - Karrfalt, 1986; Lower Cretaceous, Queensland - Walkom, 1928), and despite their absence so far of macrofossils in the New Zealand record, their presence is clear from their palynomorphs (e.g., Thorn, 2001). Like Hausmannia, some of these groups may turn up eventually, or their absence might reflect preservation bias or unresolved stratigraphic issues.

The global climatic context of the Catlins Jurassic vegetation is the late Middle Jurassic 'cool greenhouse' world (some polar ice), but which including a possible 'cold snap' (Abbink et al., 2001; Jenkyns et al., 2002; Dromart et al., 2003; Kidder and Worsley, 2010, 2012; Donnadieu et al., 2011), followed by a 'warm greenhouse' world (no polar ice) in the early late Jurassic (summarised by Holz, 2015). In Upper Jurassic deltaic sediments of Port Waikato, Ballance (1988) noted what he termed 'drop stones,' which could have been dropped by either floating trees or by ice. He made the interesting observation that there was no sign of a strand facies and that there were few wavegenerated structures. In the possible context of floating ice, he cited work on an Arctic delta, where ice damped wave action (Naidu and Mowatt, 1975). Petrographic work on the same region (Briggs et al., 2004) indicated that the sandstones were "texturally and mineralogically immature," which they surmised either meant deposition close to source, or rapid transport from an environment where physical, rather than chemical weathering predominated. They added that the latter would be consistent with the "wet, cool, or cold temperate" conditions that they understood prevailed in the high latitude Gondwana Jurassic.

In apparent contrast to these cooler estimates, Clayton and Stevens (1967) and Stevens and Clayton (1971) used oxygen isotope data from New Zealand belemnite guards to infer sea water temperature. They obtained a wide range of temperatures, but they suggested slightly lower temperatures in the Late Jurassic than now and a midlatitude position. Jenkyns et al. (2012) used the organic geochemical proxy $\mathrm{TEX}_{86}$ to derive sea surface temperatures for some Late Jurassic-Cretaceous high southern latitude sites. Their Late Jurassic data from DSDP Site 51 on the Falkland Plateau includes the late Callovian 'cold snap' of Holz (2015). Thus, these results should give an indication of minimum sea surface temperatures experienced at around 55-59 ${ }^{\circ} \mathrm{S}$ (palaeolatitude based on Müller et al., 2008; Seton et al., 2012). The minimum was around $25-26{ }^{\circ} \mathrm{C}$, although as the authors pointed out, it may not be an absolute minimum, as the sample came from close to the base of the core. Samples from the rest of the Jurassic fluctuated around $27-29^{\circ} \mathrm{C}$. The authors were under no doubt that this precluded glaciation at sea level in Antarctica, and (Jenkyns et al., 2012, p. 219) "the Southern Hemisphere was likely enjoying a tropical to sub-tropical climate that extended to high latitudes." There may be no contradiction in these temperature estimates as Jurassic climate may have changed significantly over the timespan of the Catlins sequence considered here.

As regards rainfall, Pole (2001) surmised that the Middle Jurassic climate of the Curio Bay region was "relatively dry (i.e., less than humid, but not arid) and that rainfall was infrequent, perhaps seasonal." Responding to this, Tidwell et al. (2013) asserted that "Coal beds abound in our study areas of Australia and New Zealand." They appear unfamiliar with the geology of Curio Bay, where coal seams do not "abound," but are absent, despite multiple soil horizons. Along the Otara coast an approximately 2-m thick unit of carbonaceous mud can grade into thin (a few $\mathrm{cm}$ ) coal. There are also 
very thin, very carbonaceous muds at Boat Harbour. Tidwell et al. (2013) cited Thorn's (2001, fig. 5) illustration of a tree stump in the Kawhia Harbour, North Island, that was rooted "at a coal-rich paleosurface" perhaps $10 \mathrm{~mm}$ thick, and the fact it grew in "a nearly identical flora, lacking only Donponoxylon" as further evidence of a "moist environment" at Curio Bay. However, Kawhia Harbour is not Curio Bay, and Thorn (2001) only listed the foliage taxa Cladophlebis spp. (including C. cf. C. australis, and C. cf. denticulata), Taeniopteris daintreei, and Elatocladus conferta. That these taxa are generally ubiquitous simply suggests that they had broad ecological tolerances.

Tidwell et al. (2013) went on to cite the "osmundaceous fern bases, large conifer trunks, and of conifer tree stumps with shallow root systems" at Curio Bay as further indications of a "moist environment." Without question the environment was 'moist', at least some of the time - it was a fluvial-lacustrine system after all. However, this is not the same as local rainfall. None of criteria applied by Tidwell et al. (2013) for a particularly humid climate are persuasive and, in my opinion, are outweighed by the remarkable lack of anything approaching coal at Curio Bay. Today, large conifers are a typical component of dry forests and Osmundaceae extend to areas of low annual rainfall. For example, Osmunda grows under conditions as dry as $500 \mathrm{~mm}$ mean annual rainfall, or less than $10 \mathrm{~mm}$, or even $5 \mathrm{~mm}$ in the driest month [GBIF.org (15th July 2017) GBIF Occurrence Download http://doi.org/10.15468/dl.0vrg47]. However, other than the indication of lateral roots, in my opinion, the rooting system of the Curio Bay trees is unclear. They may genuinely lack deep tap roots and sinkers, as Tidwell et al. (2013) imply, but this is the typical situation for trees (Crow, 2005). Bannan (1940) reported shallow rooted conifers where the annual rainfall was about $748 \mathrm{~mm}$ and less than $50 \mathrm{~mm}$ in the driest month. Hytteborn et al. (2005) noted that pine roots shallow in response to dry and poor soils. Schenk and Jackson (2002) pointed out that absolute rooting depth tends to increase with annual precipitation. This appears to contrast with the argument presented by Tidwell et al. (2013) that shallow root systems indicate moist situations.

The lack of a definite palaeolatitude for the Murihiku Terrane precludes easily locating the region into global reconstructions of Jurassic climate and biomes (e.g., Parrish, 1991; Hallam et al., 1993; Rees et al., 2000). However, the bulk of evidence suggests relatively cool (and dry) condi- tions for the Catlins Jurassic, which would be consistent with a high latitude location, although likely much warmer than the present.

\section{Broader Floristic Comparisons}

The closest relationships of New Zealand's Middle-Late Jurassic flora are with the Jurassic in eastern Australia and the Early Cretaceous of south-eastern and, to a lesser extent, with Western Australia. McLoughlin and Drinnan (1995) reported an assemblage from the middle or possibly late Jurassic of Mutdapilly, Queensland as containing Equisetum, Cladophlebis, Hausmannia, Sphenopteris, Taenopteris, Elatocladus, and Palissya, and they remarked that Waikawa (Curio Bay) was "strikingly similar" to their assemblage. However, one of the differences they noted was the absence of dipterideacean ferns from Curio Bay. With the discovery here of Hausmannia in strata broadly correlative with Curio Bay, that similarity is emphasised. The Early Jurassic Shaeffers Peak flora in Antarctica (Bomfleur et al., 2011) probably accumulated in the same general 'neighbourhood' as eastern Australia and the Catlins Coast. The dominant genera are reported as Equisetum, Coniopteris, and Otozamites. These are all present in the Catlins Coast, but the striking difference is in the absence of Cladophlebis and Taeniopteris.

Further afield, the decisive dating of the Botany Bay Group, on the Antarctica Peninsula, to the Middle Jurassic, c. $167 \mathrm{Ma}$ (Hunter et al., 2005) is relevant, as this is equivalent to the New Zealand Temaikan and, therefore, of similar age to the Catlins Coast assemblages. Whether following Gee (1989) or Rees and Cleal (2004), the Antarctic material has a higher diversity, both in terms of species and genera, than the Catlins Coast. This might reflect a slightly lower latitude, and warmer, Antarctica Peninsula at the time. There is a broad similarity of genera, and discovery of Hausmannia in New Zealand is similar to the late recognition of this genus from the Antarctica Peninsula (Cantrill, 1995).

The similarity of the New Zealand Jurassic vegetation with that of other nearby Gondwanan areas is not surprising. However, the recognition here of floristic links with the early Cretaceous of Victoria (McLoughlin et al., 2002; Nagalingum et al., 2005), is less expected and suggests some long-term continuity of ecology. McLoughlin et al. (2002) documented the broad floristic and physiognomic trends across the Early Cretaceous of Australia, and also further afield to India. Victoria, with evidence for distinctly cold conditions, perhaps 
even periglacial (Constantine et al., 1998) was at higher latitudes (c. $70^{\circ} \mathrm{S}$ ) in the Early Cretaceous than the Walloon flora had been in the Jurassic. This suggests either a restriction of a cold-adapted flora to high latitudes, or some other mechanism in which polar environments linger as 'relicts' (see McLoughlin et al., 2002; Bomfleur et al., 2018).

The links between the Catlins Coast Jurassic and the Victorian Early Cretaceous may extend also to plant fossil associations. McLoughlin et al. (2002) recognised a range of facies-related floristic associations in the Victorian early Jurassic, based not only on the macrofosssil content, but also on palynology and mesofossils. Future work on the Catlins Coast palynology might be productive in this respect. At present but there are only vague hints of different macrofossil associations in the Catlins Jurassic with sedimentary facies. The forests of Curio Bay grew on a sand-dominated substrate, interpreted as mostly repeated unconfined flows, in relatively dry settings. The common taxa there are Elatocladus, Cladophlebis, and Taeniopteris. In-situ stumps suggest the latter two taxa grew within a coniferous forest. Along the Otara coast, the facies is distinctly different, with more mud, and thin beds of coal. It suggests a true floodbasin environment, where water tables were high and soils often water-logged. Muddy lithologies at Otara are commonly dominated by Cladophlebis and Taeniopteris, and locally with Elatocladus as well. However, the flora is not obviously distinct from Curio Bay. Cladophlebis and Taeniopteris may have had generalised ecologies that colonised broad areas of a fluvial landscape, either welldrained, sandy soils or more water-logged, clayrich soils. The conifer component may have established itself below the initial canopy. It might be seen as a depauperate version of the Cladophlebis association (B3) of the Victorian Early Cretaceous, which was interpreted as occupying floodplains (McLoughlin et al., 2002). Elatocladus conferta-like foliage was absent in the Victorian early Cretaceous, and the only conifer in the Cladophlebis association was the needle-leaved Bellarinea.

The Little Beach assemblage shows some similarity to the Bellarinea-Taeniopteris-Rintoulia association (biofacies $\mathrm{BI}$ ) of McLoughlin et al., 2002, but still contains Elatocladus, Cladophlebis and Taeniopteris. It occurs in a fine, characteristically grey sandstone. Noda et al. (2002) included Little Beach within their meandering river and floodplain facies, but the characteristic features of a meandering system, such as epsilon cross-bedding, have not been recognised, and coal, which would support a flood basin interpretation, is absent. The presence of a floral association at Little Beach (Brothers Block, earliest Late Jurassic) distinct from that at Curio Bay (Slope Point Block, Middle Jurassic) is consistent both with the evidence of different ages and with inference of tectonic discontinuity between the two regions. The localisation of this flora in the axis of the Waikawa Syncline suggests it is the youngest Jurassic of the Murihiku Terrane.

Another floral association might be represented by the Owaka material. It is uniquely dominated by the very small-leaved Pagiophyllum, abundant Equisetum, as well as having Archangelskya. Unfortunately, the outcrop is very small and weathered, and little more can be said of it other than it appears to be generalised fluvial. In other instances, such as Otara, Equisetum probably formed monospecific patches in shallow, standing water.

Although Cheirolepidiaceae are known to have been a part of the Catlins vegetation based on pollen evidence, the associated foliage is not known, in part due to the lack of cuticle. This hampers closer comparison with the Victorian flora.

In the absence of clear facies control of these associations, the differences may be stratigraphic, and reflect climate differences. However, one other factor was likely an important agent of structuring the environment - fire. There is field evidence of abundant charcoal at several localities, and this is a focus of future research. Fires were likely to have had various ecological effects and may have discriminated between evergreen and deciduous taxa. Likewise, fire was an important component in the Early Cretaceous of Victoria (McLoughlin et al., 2002), although was curiously absent from all foliage-based associations.

Several of the taxa found in New Zealand (e.g., Cladophlebis, Hausmannia, Otozamites, Taeniopteris, Elatocladus) are shared with early Cretaceous assemblages in Western Australia (e.g., McLoughlin, 1996). However, the importance of these taxa being present is probably outweighed by other taxa which occur in Western Australia and not New Zealand (e.g., Phyllopteroides, Roebuckia and the short-leaved Araucaria, McLoughlin, 1996).

\section{CONCLUSION}

The strata of the Catlins Coast incorporate several beds in which plant macrofossils occur. The genera now recognised include Equisetum, Cladophlebis, Coniopteris, Sphenopteris, Rintoulia, 
Hausmannia, Archangelskya, Taeniopteris, Otozamites, Otozamites, Pseudoctenis? Pachydermophyllum, 'Palyssia', Elatocladus, Bellarinea, Pagiophyllum, Pityophyllum, Podozamites, and Araucarites. Cladophlebis and Taeniopteris predominate, in some cases with Elatocladus and locally Equisetum is abundant. The other taxa are usually much less common.

Most of the facies were sandy and probably formed on relatively well-drained, seasonally dry, flash-flood prone alluvial plains. However, the Otara Coast preserves facies in which peat and muddy sediments were sometimes prominent, as flood-basin deposits. This environment may be contrasted with that of Curio Bay, higher in the regional section, where the environment was interpreted to be dominated by unconfined flashy fluvial flows, where sediments were poorly sorted and typically not muddy or peaty. However, both environments preserved a succession of fossil forests.

Beyond likely being in relatively high palaeolatitudes, the precise latitude is far from clear. However, there are several lines of evidence, including small leaves and at least three putatively deciduous taxa, which suggest relativity cool conditions, despite the global greenhouse conditions of the time. The floristic links are closest with eastern Australian Jurassic assemblages, but also with more distant parts of Gondwana, including Antarctica and India. Interestingly, there are links with the high-latitude Early Cretaceous of Victoria.

\section{ACKNOWLEDGEMENTS}

Special thanks to the McKenzie and Stratford families who have provided me with Southland hospitality and accommodation on my excursions over the years. Many thanks also to other 'locals', including the Cooks, Popes, Smiths, Watsons, and Ericsons, who, in true kiwi fashion, have freely given access over their land and to their knowledge of the country. Thanks also to A. Kemp and V. Leung for supporting my research. The comments of two reviewers greatly improved the paper and are much appreciated.

\section{REFERENCES}

Abbink, O.A., Targarona, J., Brinkhuis., H., and Visscher, H. 2001. Late Jurassic to Early Cretaceous paleoclimatic evolution of the southern North Sea. Global and Planetary Change, 30:231-256. https://doi.org/10.1016/S0921-8181(01)00101-1

Adams, C.J. 2010. Lost terranes of Zealandia: possible development of late Paleozoic and early Mesozoic sedimentary basins at the southwest Pacific margin of Gondwanaland, and their destination as terranes in southern South America. Andean Geology, 37:442-454. https:// doi.org/10.5027/andgeov37n2-a10

Adams, C.J., Campbell, H.J., and Griffin, W.L. 2007. Provenance comparisons of Permian to Jurassic tectonostratigraphic terranes in New Zealand: perspectives from detrital zircon age patterns. Geological Magazine, 144:701-729. https://doi.org/10.1017/s0016756807003469

Arber, E.A.N. 1913. A preliminary note on the fossil plants of the Mount Potts Beds, New Zealand, collected by Mr D.G. Lillie, Biologist to Captain Scott's Antarctic Expedition in the 'Terra Nova'. Proceedings of the Royal Society London B, 86:344-347. https://doi.org/ 10.1098/rspb.1913.0030

Arber, E.A.N. 1917. The earlier Mesozoic floras of New Zealand. New Zealand Geological Survey Bulletin, 6:1-80.

Arber, E.A.N. 1905. Catalogue of the fossil plants of the Glossopteris Flora in the Department of Geology, British Museum (Nat. Hist.). British Museum, London.

Ballance, P.F. 1988. The Huriwai braidplain delta of New Zealand: a late Jurassic, coarsegrained, volcanic-fed depositional system in a Gondwana forearc basin, p. 430-444. In Nemec, W. and Steel, R.J. (eds.), Fan Deltas: Sedimentology and Tectonic Settings. Blackie and Son, Glasgow.

Ballance, P.F. and Campbell, J.D. 1993. The Murihiku arc-related basin of New Zealand (Triassic-Jurassic), South Pacific Sedimentary Basins, p. 21-33. In Ballance, P.F. (ed.), Sedimentary Basins of the World. Volume 2. Elsevier, Amsterdam.

Bannan, M.W. 1940. The root systems of Northern Ontario conifers growing in sand. American Journal of Botany, 27:108-114. https://doi.org/10.2307/2436693 
Barnard, P.D.W. 1973. Mesozoic floras, p. 175-188. In Hughes, N.F. (ed.), Organisms and Continents Through Time, Palaeontology Special Paper 12. Palaeontological Society, London.

Bartrum, J.A. 1921. Note on the Port Waikato Mesozoic flora. New Zealand Journal of Science and Technology, 4:258.

Birkenmajer, K. and Ociepa, A.M. 2008. Plant-bearing Jurassic strata at Hope Bay, Antarctic Peninsula (West Antarctica): geology and fossil-plant description. Studia Geologia Polonica, 128:5-96.

Blaschke, P.M. and Grant-Mackie, J.A. 1976. Mesozoic leaf genus Taeniopteris at Port Waikato and Clent Hills, New Zealand. New Zealand Journal of Geology and Geophysics, 19:933941. https://doi.org/10.1080/00288306.1976.10420747

Bomfleur, B., Blomenkemper, P., Kerp, H., and McLoughlin, S. 2018. Polar regions of the Mesozoice Paleogene Greenhouse World as refugia for relict plant groups, p. 593-611. In Krings, M., Harper, C.J., Cúneo, N.R., and Rothwell, G.W. (eds.), Transformative Paleobotany. Papers to Commemorate the Life and Legacy of Thomas N. Taylor. Academic Press, London. https://doi.org/10.1016/B978-0-12-813012-4.00024-3

Bomfleur, B., Pott, C., and Kerp, H. 2011. Plant assemblages from the Shafer Peak Formation (Lower Jurassic), north Victoria Land, Transantarctic Mountains. Antarctic Science, 23:188208. https://doi.org/10.1017/s0954102010000866

Bose, M.N. and Banerji, J. 1981. Cycadophytic leaves from Jurassic-Lower Cretaceous rocks of India. The Palaeobotanist, 28-29:218-300.

Bose, M.N., Kutty, T.S., and Maheshwari, H.K. 1982. Plant fossils from the Gangapur Formation. The Palaeobotanist, 30:121-142.

Bose, M.N. and Sah, S.C.D. 1968. Some pteridophytic remains from the Rajmahal Hills, Bihar. The Palaeobotanist, 16:12-28.

Braun, C.F.W. 1843 Beiträge zur Urgeschichte der Pflanzen. p. 1-46. In Münster, G. (ed.), Beiträge zur Petrefacten-Kunde. Verlag der Buchner'schen Buchhandlung, Bayreuth.

Briggs, R.M., Middleton, M.P., and Nelson, C.S. 2004. Provenance history of a Late TriassicJurassic Gondwana margin forearc basin, Murihiku Terrane, North Island, New Zealand: petrographic and geochemical constraints. New Zealand Journal of Geology and Geophysics, 47:589-602. https://doi.org/10.1080/00288306.2004.9515078

Brongniart, A. 1828. Prodrome d'une histoire des végétaux fossiles. F.G. Levrault, Strasbourg.

Brongniart, A. 1832. Histoire des vegetaux fossiles ou recherches botaniques et geologiques sur les vegetaux renfermes dans les diverses couches du globe. G. Dufour and E. D'Ocagne, Paris.

Brongniart A.T. 1849. Tableau des genres de végétaux fossiles considérés sous le point de vue de leur classification botanique et de leur distribution geologique. Extrait du dictionnaire universel d'histoire naturelle, 13:1-127.

Campbell, H.J., Mortimer, N., and Turnbull, I.M. 2003. Murihiku Supergroup, New Zealand: redefined. Journal of the Royal Society of New Zealand, 33:85-95. https://doi.org/10.1080/ 03014223.2003 .9517722

Campbell, J.D. and Coombs, D.S. 1966. Murihiku Supergroup (Triassic-Jurassic) of Southland and South Otago. New Zealand Journal of Geology and Geophysics, 9:393-398. https:// doi.org/10.1080/00288306.1966.10422483

Cantrill, D. 1995. The occurrence of the fern Hausmannia Dunker (Dipteridaceae) in the Cretaceous of Alexander Island, Antarctica. Alcheringa, 19:243-254. https://doi.org/10.1080/ 03115519508619508

Cantrill, D.J. 2000. A Cretaceous (Aptian) flora from President Head, Snow Island, Antarctica. Palaeontographica Abt. B, 253:153-191. https://doi.org/10.1127/palb/253/2000/153

Carter, R.M. 1979. Trench-slope channels from the New Zealand Jurassic: the Otekura Formation, Sandy Bay, South Otago. Sedimentology, 26:475-496. https://doi.org/10.1111/ j.1365-3091.1979.tb00925.x

Choo, T.Y.S., Escapa, I.H., and Bomfleur, B. 2016. Monotypic colonies of Clathropteris meniscioides (Dipteridaceae) from the Early Jurassic of central Patagonia, Argentina: implications for taxonomy and palaeoecology. Palaeontographica, Abt. B, 294:85-109.

Choo, T.Y.S. and Escapa, I.H. 2018. Assessing the evolutionary history of the fern family Dipteridaceae (Gleicheniales) by incorporating both extant and extinct members in a combined phylogenetic study. American Journal of Botany, 105:1-14. https://doi.org/10.1002/ ajb2.1121 
Constantine, A., Chinsamy, A., Vickers-Rich, P., and Rich, T.H. 1998. Periglacial environments and polar dinosaurs. South African Journal of Science, 94:137-141.

Coombs, D.S., Cook, N.D.J., Kawachi, Y., Johnstone, R.D., and Gibson, I.L. 1996. Park Volcanics, Murihiku Terrane, New Zealand: petrology, petrochemistry, and tectonic significance. New Zealand Journal of Geology and Geophysics, 39:469-492. https://doi.org/ 10.1080/00288306.1996.9514727

Corsin, P. and Waterlot, M. 1979. Palaeobiogeography of the Dipteridaceae and Matoniaceae of the Mesozoic. p. 51-70. In Laskar, B. and Raja Rao, C.S. (eds.), Proceedings of the Fourth International Gondwana Symposium. Hindustan Publishing Corporation, Delhi.

Creber, G.T. and Chaloner, W.G. 1985. Tree growth in the Mesozoic and early Tertiary and the reconstruction of palaeoclimates. Palaeogeography, Palaeoclimatology, Palaeoecology, 52:35-60.

Crié, L. 1889. Beitrage zur Kenntniss der fossilen Flora einiger Inseln des Südpacifischen und Indischen Ocean. Palaeontologia, 5:77-91.

Crow, P. 2005. The influence of soils and species on tree root depth. Edinburgh Forestry Commission Information, Note FCINO78:1-8.

De Candolle. 1804. Essai sur les Propriétés Médicales des Plantes 49. Didot Jeune, Paris.

De Jersey, N.J. and Grant Mackie, J.A. 1989. Palynofloras from the Permian, Triassic and Jurassic of New Caledonia (South Pacific Ocean). New Zealand Journal of Geology and Geophysics, 32:463-476.

De Jersey, N.J. and Raine, J.I. 1990. Triassic and earliest Jurassic miospores from the Murihiku Supergroup, New Zealand. New Zealand Geological Survey Paleontological Bulletin, 62:1164.

Doludenko, M. 1971. Thinnfeldia - the younger synonym of Pachypteris. Paleontologičeskij Žurnal, 2:99-104.

Doludenko, M.P., Kostina, E.I., and Samylina, V.A. 1998. A re consideration of Pachypteris Brongniart and Thinnfeldia Ettingshausen. Palaeontographica, B247:55-64.

Donnadieu, Y, Dromart, G., Goddéris, Y., Pucéat, E., Brigaud, B., Dera, G., Dumas, C., and Olivier, N. 2011. A mechanism for brief glacial episodes in the Mesozoic greenhouse. Paleoceanography, 26:PA3212. https://doi.org/10.1029/2010pa002100

Douglas, J.G. 1969. The Mesozoic Floras of Victoria Parts 1 and 2. Geological Survey of Victoria Memoir, 28:1-310.

Drinnan, A.N. and Chambers, T.C. 1985. A reassessment of Taeniopteris daintreei from the Victorian Early Cretaceous: a member of the Pentoxylales and a significant Gondwanaland plant. Australian Journal of Botany, 33:89-100. https://doi.org/10.1071/bt9850089

Drinnan, A.N. and Chambers, T.C. 1986. Flora of the Lower Cretaceous Koonwarra fossil bed (Korumburra Group) South Gippsland, Victoria. Association of Australasian Palaeontologists Memoir, 3:1-77.

Dromart, G., Garcia, J.-P., Picard, S., Atrops, F., Lécuyer, C., and Sheppard, S.M.S. 2003. Ice age at the Middle-Late Jurassic transition? Earth and Planetary Science Letters, 213:205220. https://doi.org/10.1016/s0012-821x(03)00287-5

Dunker, W. 1846. Monographie der norddeutschen Wealdenbildung. Ein Beitrag zur Geognoise und Naturgeschichte der Vorwelt. Oehme und Müller, Braunschweig.

Edwards, W.N. 1934. Jurassic plants from New Zealand. Annals and Magazine of Natural History, 10:81-109. https://doi.org/10.1080/00222933408654794

Endlicher, S. 1847. Synopsis Coniferarum. Apud Scheitlin and Zollikofer, Sangalli.

Engler, A. 1892. Syllabus der Vorlesungen über specielle und medicinischpharmaceutische Botanik. Gebruder Borntraeger, Berlin.

Feistmantel, O. 1877. Jurassic (Liassic) flora of the Rajmahal Group, in the Rajmahal Hills. Memoirs of the Geological Survey of India, Palaeontologica Indica, Ser. 2, 1:1-110.

Florin, R. 1952. On two conifers from the Jurassic of south-eastern Australia. The Palaeobotanist, 1:177-182.

Frenguelli, J. 1947. El género Cladophlebis y sus representantes en la Argentina. Anales del Museo de La Plata (Nueva Serie), 2:1-74.

Frenguelli, J. 1949. Addenda a la flora del Gondwana Superior en la Argentina. I. Palissya conferta Feistm. y Palissya jabalpurensis Feistm. en el jurasico superior del Chubut, Patagonia. De Physis, 20:139-158.

Gee, C.T. 1989. Revision of the Late Jurassic/Early Cretaceous flora from Hope Bay, Antarctica. Palaeontographica, B213:149-214. 
Gould, R.E. 1968. Morphology of Equisetum laterale Phillips, 1829, and E. bryanii sp. nov. from the Mesozoic of south-eastern Queensland. Australian Journal of Botany, 16:153-176. https://doi.org/10.1071/bt9680153

Gould, R.E. 1974. The fossil flora of the Walloon Coal Measures: a survey. Proceedings of the Royal Society of Queensland, 85:33-41.

Gould, R.E. 1975. The succession of Australian pre-Tertiary megafossil floras. Botanical Review, 41:453-483. https://doi.org/10.1007/bf02860833

Gould, R. 1980. The coal-forming flora of the Walloon Coal Measures. Coal Geology, 1:83-105.

Grant-Mackie, J.A., Aita, Y., Balme, B.E., Campbell, H.J., Challinor, A.B., MacFarlan, D.A.B., Molnar, R.E., Stevens, G.R., and Thulborn, R.A. 2000. Jurassic palaeobiogeography of Australasia. Memoir of the Association of Australian Palaeontologists, 23:311-353.

Gupta, S.S. 1986. On Taeniopteris crassinervis (Feistmantel) Walkom from Rajmahal Hills, Bihar, India. Review of Palaeobotany and Palynology, 49:195-202. https://doi.org/10.1016/ 0034-6667(86)90027-8

Guy-Ohlson, D. 1979. Paleobotanisk exkursion i Nya Zeelands jura: Curio Bay - den förstende skogen. Fauna och Flora, 6:271-282.

Hallam, A., Crame, J.A., Mancenido, M.O., Francis, J., and Parrish, J.T. 1993. Jurassic climates as inferred from the sedimentary and fossil record [and Discussion]. Philosophical Transactions: Biological Sciences, 341:287-296.

Halle, T.G. 1913. The Mesozoic flora of Graham Land. Wissenschaftliche Ergebnisse der Schwedischen Südpolar-expedition 1901-1903, 3:1-123.

Harris, T.M. 1932. The fossil flora of Scoresby Sound East Greenland, part 2: description of seed plants Incertae sedis together with a discussion of certain cycadophyte cuticles. Meddelelser om Gronland, 85:4-7.

Harris, T.M. 1935. The fossil flora of Scoresby Sound, East Greenland, part 4: Ginkgoales, Coniferales, Lycopodiales and isolated fructifications. Meddelelser om Gronland 112:1-176.

Harris, T.M. 1961.The Yorkshire Jurassic flora I. Thallophyta-Pteridophyta. British Museum of Natural History, London.

Harris, T.M. 1964. The Yorkshire Jurassic flora. II Caytoniales, Cycadales and pteridopserms. British Museum (Natural History), London.

Harris, T.M. 1969a. The Yorkshire Jurassic flora. III Bennettitales. British Museum (Natural History), London.

Harris, T.M. 1969b. Naming a fossil conifer, p. 243-251. In Sanatapu, H. (ed.), J. Sen Memorial Volume. Botanical Society of Bengal, Calcutta.

Harris, T.M. 1979. The Yorkshire Jurassic Flora. 5. Coniferales. British Museum (Natural History), London.

Hector, J, 1886. Detailed Catalogue and Guide to the Geological Exhibits, New Zealand Court, Indian and Colonial Exhibition, London. Government Printer, Wellington.

Heer O. 1881. Contributions à la flore fossile du Portugal. Communicaçoes da seccao dos Trabalhos Geologicos de Portugal. Imprimerie de l'Académie Royale des Sciences, Lisbonne.

Herbst, R. 1966. Nuevos elementos de la flora fosil de la formacion Baquero, Santa Cruz, Patagonia. Acta Geol. Lilloana, 8:75-86.

Herbst, R. 1971. Palaeophytologia Kurtziana III. 7. Revision de las especies Argentinas del genero Cladophlebis. Ameghiniana, 8:265-281.

Herbst, R. 1979. Review of the Australian Dipteridaceae. Proceedings of the Linnean Society of New South Wales, 103:7-22.

Holz, M. 2015. Mesozoic paleogeography and paleoclimates. A discussion of the diverse greenhouse and hothouse conditions of an alien world. Journal of South American Earth Sciences, 61:91-107. https://doi.org/10.1016/j.jsames.2015.01.001

Hunter, M.A., Cantrill, D.J., Flowerdew, M., and Millar, I.L. 2005. Middle Jurassic age for the Botany Bay Group implications for Weddell Sea creation and southern hemisphere biostratigraphy. Journal of the Geological Society of London, 162:745-748. https://doi.org/ 10.1144/0016-764905-051

Hytteborn, H., Maslov, A.A., and Nazimova, D.I. 2005. Boreal forests of Eurasia, p. 23-99. In Andersson, F. (ed.), Ecosystems of the World 6. Coniferous Forests, Elsevier, Amsterdam.

Jansson, I.-M., McLoughlin, S., Vajda, V., and Pole, M. 2008. An Early Jurassic flora from the Clarence-Moreton Basin, Australia. Review of Palaeobotany and Palynology, 150:5-21. https://doi.org/10.1016/j.revpalbo.2008.01.002 
Jenkyns, H.C., Jones, C.E., Gröcke, D.R., Hesselbo, S.P., and Parkinson, D.N. 2002. Chemostratigraphy of the Jurassic System: applications, limitations and implications for palaeoceanography. Journal of the Geological Society London, 159:351-378. https://doi.org/ 10.1144/0016-764901-130

Jenkyns, H.C., Schouten-Huibers, L., Schouten, S., Sinninghe, and Damst, J.S. 2012. Warm Middle Jurassic-Early Cretaceous high-latitude sea-surface temperatures from the Southern Ocean. Climate of the Past, 8:215-226. https://doi.org/10.5194/cp-8-215-2012

Johnston, M.R., Raine, J.I., and Watters, W.A. 1987. Drumduan Group of east Nelson, New Zealand: plant-bearing Jurassic arc rocks metamorphosed during terrane interaction. Journal of the Royal Society of New Zealand, 17:275-301. https://doi.org/10.1080/ 03036758.1987 .10418162

Karrfalt, E. 1986. New observations on the structure and development of Nathorstianella. Review of Palaeobotany and Palynology, 47:1-8. https://doi.org/10.1016/00346667(86)90002-3

Kidder, D.L. and Worsley, T.R. 2010. Phanerozoic large igneous provinces (LIPs), HEATT (Haline Euxinic Acidic Thermal Transgression) episodes and mass extinctions. Palaeogeography, Palaeoclimatology, Palaeoecology, 295:162-191. https://doi.org/10.1016/ j.palaeo.2010.05.036

Kidder, D.L. and Worsley, T.R. 2012. Human-induced hothouse climate? GSA Today, 22:4-11. https://doi.org/10.1130/g131a.1

Kidston, R. and Gwynne-Vaughan, D.T. 1907. On the fossil Osmundaceae. Part I. Transactions of the Royal Society of Edinburgh, 45:759-780.

Kidston, R. and Gwynne-Vaughan, D.T. 1908. On the fossil Osmundaceae. Part II. Transactions of the Royal Society of Edinburgh, 46:213-232.

Kidston, R. and Gwynne-Vaughan, D.T. 1909. On the fossil Osmundaceae. Part III. Transactions of the Royal Society of Edinburgh, 46:651-667.

Kidston, R. and Gwynne-Vaughan, D.T. 1910. On the fossil Osmundaceae. Part IV. Transactions of the Royal Society of Edinburgh, 47:455-477.

Li, P.J. 1964. Fossil plants from the Hsuchiaho Kwangyuan Series of Kwangyuan, Northern Sichuan. Memoirs Institute of Geology and Palaeontology Academica Sinica, 3:101-178. (In Chinese with English summary)

Linnaeus, C. 1753. Species Plantarum. Impensis Laurentii Salvii, Stockholm.

Mackie, J.B. 1935. The geology of the Glenomaru Survey District, Otago, New Zealand. Transactions of the Royal Society of New Zealand, 64:275-320.

McClelland, J. 1850. Reports of the Geological Survey India for 1848-49, J.C. Sherriff. Military Orphan Press, Calcutta.

McCoy, F. 1874. Prodromus of the Palaeontology of Victoria. Geological Survey or Victoria, Melbourne.

McKay, A. 1877. Reports Relative to Collection of Fossils in the South-East District of the Province of Otago. Reports Geological Explorations. Geological Survey of New Zealand during 1873-74. New Zealand Government Printer, Wellington.

McLoughlin, S. 1996. Early Cretaceous macrofloras of Western Australia. Records of the Western Australian Museum, 18:19-65.

McLoughlin, S. and Hill, R.S. 1996. The succession of Western Australian Phanerozoic floras, p. 61-80. In Hopper, S.D, Chappill, J.A., Harvey, M.S., and George, A.S. (eds.), Gondwanan Heritage: Past, Present and Future of the Western Australian Biota (Proceedings of the Conference on Systematics, Evolution and Conservation of the Western Australian Biota, Perth, 1993). Surrey Beatty, Sydney.

McLoughlin, S. and Drinnan, A.N. 1995. A Middle Jurassic flora from the Walloon Coal Measures, Mutdapilly, Queensland, Australia. Memoirs of the Queensland Museum, 38:257272.

McLoughlin, S. and McNamara, K. 2001. Ancient Floras of Western Australia. Publication of the Department of Earth and Planetary Sciences, Western Australian Museum.

McLoughlin, S., Tosolini, A.-M.P., Nagalingum, N.S., and Drinnan, A.N. 2002. The Early Cretaceous (Neocomian) flora and fauna of the lower Strzelecki Group, Gippsland Basin, Victoria, Australia. Memoirs of the Australasian Association of Paleontologists, 26:1-144.

McQueen, D.R. 1956. Leaves of Middle and Upper Cretaceous pteridophytes and cycads from New Zealand. Transactions of the Royal Society of New Zealand, 83:673-685. 
Medwell, L.M. 1954. A review and revision of the flora of the Victorian Lower Jurassic. Proceedings of the Royal Society of Victoria, 65:63-111.

Miall, A.D. 1977. A review of the braided-river depositional environment. Earth Science Reviews, 13:1-62. https://doi.org/10.1016/0012-8252(77)90055-1

Miall, A.D. 1978. Lithofacies types and vertical profile models in braided river deposits: a summary, p. 597-604. In Miall, A.D. (ed.), Fluvial Sedimentology. Canadian Society of Petroleum Geologists Memoir 5, Calgary.

Mildenhall, D.C. 1970. Checklist of valid and invalid plant macrofossils from New Zealand. Transactions of the Royal Society of New Zealand, 8:77-89.

Miller, C.N., 1967. Evolution in the fern genus Osmunda. Contributions Museum of Paleontology of the University of Michigan, 21:139-203.

Miller, I.M. and Hickey, L.J. 2008. The fossil flora of the Winthrop Formation (Albian Early Cretaceous) of Washington State, USA. Part I: Bryophyta and Pteridophytina. Bulletin of the Peabody Museum of Natural History, 49:135-180. https://doi.org/10.3374/0079-032x49.2.135

Mortimer, N. 2004. New Zealand's geological foundations. Gondwana Research, 7:261-272. https://doi.org/10.1016/s1342-937x(05)70324-5

Mortimer, N., Tulloch, A.J., Sparks, R.N., Walker, N.W., Ladley, E., Allibone, A., and Kimbrough, D.L. 1999. Overview of the median batholith, New Zealand: a new interpretation of the geology of the Median Tectonic Zone and adjacent rocks. Journal of African Earth Sciences, 29:257-268. https://doi.org/10.1016/s0899-5362(99)00095-0

Müller, R.D., Sdrolias, M., Gaina, C., and Roest, W.R. 2008. Age, spreading rates and spreading asymmetry of the world's ocean crust. Geochemistry, Geophysics, Geosystems, 9:Q04006. https://doi.org/10.1029/2007GC001743

Nagalingum, N.S. and Cantrill, D.C. 2006. Early Cretaceous Gleicheniaceae and Matoniaceae (Gleicheniales) from Alexander Island, Antarctica. Review of Palaeobotany and Palynology, 138:73-93. https://doi.org/10.1016/j.revpalbo.2005.11.001

Nagalingum, N.S., Drinnan, A.N., and Mcloughlin, S. 2005. A new fossil conifer, Bellarinea richardsii, from the Early Cretaceous Strzelecki Group, southeastern Victoria. Proceedings of the Royal Society of Victoria, 117:1-12.

Naidu, A.S. and Mowatt, T.C. 1975. Depositional environments and sediment characteristics of the Colville and adjacent deltas, north Arctic Alaska, p. 283-309. In Broussard, M.L. (ed.), Deltas - Models for Exploration. Houston Geological Society, Houston.

Nathorst, A.G. 1897. Zur mesozoischen Flora Spitzbergens. Kongliga Svenska Vetenskapsakademiens. Handlingar, 30:1-77.

Noda, A., Takeuchi, M., and Adachi, M. 2002. Fan deltaic-to-fluvial sedimentation of the Middle Jurassic Murihiku Terrane, Southland, New Zealand. New Zealand Journal of Geology and Geophysics, 45:297-312. https://doi.org/10.1080/00288306.2002.9514975

Noda, A., Takeuchi, M., and Adachi, M. 2004. Provenance of the Murihiku Terrane, New Zealand: evidence from the Jurassic conglomerates and sandstones in Southland. Sedimentary Geology, 164:203-222. https://doi.org/10.1016/j.sedgeo.2003.10.003

Oldham, T. and Morris, J. 1863. Fossil Flora of the Rajmahal Series in the Rajmahal Hills. Memoirs of the Geological Society of India. Palaeontologia Indica Series I, 1:1-52.

Parica, C.A., Salani, F.M., Vera, E., Remesal, M., and Césari, S.N. 2007. Geología de la Formación Cerro Negro (Cretácico) en Isla Livingston: aportes a su geocronología y contenido paleontológico. Revista de la Asociacion Geologica Argentina, 62:553-567.

Parris, K.M., Drinnan, A.N., and Cantrill, D.J. 1995. Palissya cones from the Mesozoic of Australia and New Zealand. Alcheringa, 19:87-111. https://doi.org/10.1080/ 03115519508619268

Parrish, J.T. 1991. Jurassic climate and oceanography of the Pacific region, p. 365-379. In Westermann, G.E.G. (ed.), The Jurassic of the circum-Pacific. Cambridge University Press, Cambridge.

Pattemore, G.A. 2000. A new Early Jurassic pteridosperm fructification from Queensland. Journal of African Earth Science, 31:187-193. https://doi.org/10.1016/s0899-5362(00)00083-x

Pattemore, G.A., Rigby, J.F., and Playford, G. 2014. Palissya: A global review and reassessment of eastern Gondwanan material. Review of Palaeobotany and Palynology, 210:50-61. https:// doi.org/10.1016/j.revpalbo.2014.08.002 
Pattemore, G.A. and Rozefelds, A. 2019. Palissya- absolutely incomprehensible or surprisingly interpretable: a new morphological model, affiliations and phylogenetic insights. Acta Palaeobotanica, 59:181-214. https://doi.org/10.2478/acpa-2019-0015

Person, C.P. and Delevoryas, T. 1982. The Middle Jurassic flora of Oaxaca. Mexico. Palaeontographica, B180:82-119.

Peyrot, D., Playford, G., Mantle, D.J., Backhouse, J., Milne, L.A., Mack, C.L., Carpenter, R.J., Foster, C., Mory, A.J., McLoughlin, S., Vitacca, J., Scibiorski, J., and Bevan, J. 2019. The greening of Western Australian landscapes: the Phanerozoic plant record. Journal of the Royal Society of Western Australia, 102:52-82.

Pole, M.S. 1999. Structure of a near-polar latitude forest from the New Zealand Jurassic. Palaeogeography, Palaeoclimatology, Palaeoecology, 147:121-139. https://doi.org/10.1016/ s0031-0182(98)00151-5

Pole, M.S. 2000. Mid-Cretaceous conifers from the Eromanga Basin, Australia. Australian Systematic Botany, 13:153-197. https://doi.org/10.1071/sb99001

Pole, M. 2001. Repeated flood events and fossil forests at Curio Bay (Middle Jurassic), New Zealand. Sedimentary Geology, 144:223-242. https://doi.org/10.1016/s0037-0738(00)001858

Pole, M. 2004. Early-Middle Jurassic stratigraphy of the Fortrose-Chaslands region, southernmost South Island, New Zealand. New Zealand Journal of Geology and Geophysics, 47:129-139. https://doi.org/10.1080/00288306.2004.9515042

Pole, M. 2009. Vegetation and climate of the New Zealand Jurassic. GFF, 131:105-111. https:// doi.org/10.1080/11035890902808948

Pole, M. and McLoughlin, S. 2017. The first Cenozoic Equisetum from New Zealand. Geobios, 50:259-265. https://doi.org/10.1016/j.geobios.2017.04.001

Pole, M., Wang, Y., Bugdaeva, E.V., Dong, C., Tian, N., Li, L., and Zhou, N. 2016. The rise and demise of Podozamites in east Asia - An extinct conifer life style. Palaeogeography, Palaeoclimatology, Palaeoecology, 464:97-109. https://doi.org/10.1016/j.palaeo.2016.02.037

Pott, C. and Krings, M. 2010. Gymnosperm foliage from the Upper Triassic of Lunz, Lower Austria: an annotated check list and identification key. Geo.Alp, 7:19-38.

Raine, J.I. 1982. Observations on Arber's (1917) collections of Triassic-Jurassic plant macrofossils from New Zealand. New Zealand Geological Survey Report PAL, 58:1-8.

Raine, J.I. 1987. Jurassic plant microfossils and macrofossils from Murihiku Supergroup, Manganui Valley, Awakino District (North Island, New Zealand). New Zealand Geological Survey Record, 20:127-138.

Raine, J.I. and Pole, M.S. 1988. Middle Jurassic forest beds, Curio Bay. New Zealand Geological Survey Record, 33:47-57.

Raine, J.I., Mildenhall, D.C., and Kennedy E.M. 2011. New Zealand fossil spores and pollen: an illustrated catalogue. 4th edition. GNS Science miscellaneous series no. 4. http:// data.gns.cri.nz/sporepollen/index.htm

Rao, A.R. 1964. Stachyotaxus sampathkumarani sp. nov. from Onthea in the Rajmahal Hills, Bihar. The Palaeobotanist, 12:217-219.

Rees, P.M. 1993. Dipterid ferns from the Mesozoic of Antarctica and New Zealand and their stratigraphical significance. Palaeontology, 36:637-656.

Rees, P.M., Ziegler, A.M., and Valdes, P.J. 2000. Jurassic phytogeography and climates: new data and model comparisons, p. 297-318. In Huber, B.T., Macleod, K.G., and Wing, S.L. (eds.), Warm Climates in Earth History. Cambridge University Press, Cambridge.

Rees, P.M. and Cleal, C.J. 1993. Marked polymorphism in Archangelskya furcata, a pteridospermous frond from the Jurassic of Antarctica. Special Papers in Palaeontology, 49:85-100.

Rees, P.M. and Cleal, C.J. 2004. Lower Jurassic floras from Hope Bay and Botany Bay, Antarctica. Special Papers in Palaeontology, 72:1-90.

Retallack, G.J. 1981. Middle Triassic megafossil plant remains from Long Gully, near Otematata, north Otago, New Zealand. Journal of the Royal Society of New Zealand, 11:167-200. https:/ /doi.org/10.1080/03036758.1981.10421836

Retallack, G.J. 1983. Middle Triassic megafossil marine algae and land plants from near Benmore Dam, southern Canterbury, New Zealand. Journal of the Royal Society of New Zealand, 13:129-154. https://doi.org/10.1080/03036758.1983.10415325

Rigby, J.F. 1978. Jurassic plant fossils from the Walloon Coal Measures at Rosewood Consolidated Colliery. Queensland Government Mining Journal, 78:320-325. 
Ruggiero, M.A., Gordon, D.P., Orrell, T.M., Bailly, N., Bourgoin, T., Brusca, R.C., Cavalier-Smith, T., Guiry, M. D., and Kirk, P.M. 2015. A higher level classification of all living organisms. PLoS ONE, 10:e0119248. https://doi.org/10.1371/journal.pone.0119248

Sah, S.C.D. 1965. Palaeobotanical evidence on the age of the Khatangi Beds (?Dubrajpur), in the Rajmahal Hills, Bihar. The Palaeobotanist, 13:218-221.

Sahni, B. 1948. The Pentoxylaceae: A new group of Jurassic gymnosperms from the Rajmahal Hills of India. Botanical Gazette, 110:47-80.

Sahni, B. and Rao, A.R. 1933. On some Jurassic plants from the Rajmahal Hills. Journal and Proceedings Asiatic Society of Bengal (New Series), 27:183-208.

Schenk, H.J. and Jackson, R.B. 2002. Rooting depths, lateral root spreads and below-ground/ above-ground allometries of plants in water-limited ecosystems. Journal of Ecology, 90:480494. https://doi.org/10.1046/j.1365-2745.2002.00682.x

Schomburgk, M.R. 1848. Reisen in Britisch-Guiana in den Jahren 1840-44. J.J. Weber, Leipzig.

Schweitzer, H.J. and Kirchner, M. 1996. Die rhaeto-jurassischen floren des Iran und Afganistans; 9, Coniferophyta. Palaeontographica, B338:77-139.

Schimper, W.P. 1869. Traité de Paléontologie Végétale. Tome Premier. Bailliére et Fils, Paris.

Seton, M., Müller, R.D., Zahirovic, S., Gaina, C., Torsvik, T., Shephard, G., Talsma, A., Gurnis, M., Turnerf, M., Maus, S., and Chandler, M. 2012. Global continental and ocean basin reconstructions since $200 \mathrm{Ma}$. Earth-Science Reviews, 113:212-270. https://doi.org/10.1016/ j.earscirev.2012.03.002

Seward, A.C. 1894. The Wealden Flora. Part I-Thallophyta-Pteridophyta. British Museum (Natural History), London.

Seward, A.C. 1904. On a collection of Jurassic plants from Victoria. Records of the Geological Survey of Victoria, 1:155-211.

Seward, A.C. 1911. The Jurassic flora of Sutherland. Transactions of the Royal Society of Edinburgh, 47:643-709. https://doi.org/10.1017/s0080456800003872

Seward, A.C. 1919. Fossil Plants. Vol. 4. Ginkgoales, Coniferales, Gnetales. Cambridge University Press, Cambridge.

Seward, A.C. and Dale, E. 1901. On the structure and affinities of Dipteris, with notes on the geological history of the Dipteridinae. Philosophical Transactions of the Royal Society of London, B194:487-513.

Speden, I.G. 1958. A note on the age of the Jurassic flora of Owaka Creek, south-east Otago, New Zealand. New Zealand Journal of Geology and Geophysics, 1:530-532. https://doi.org/ 10.1080/00288306.1958.10422785

Speden, I.G. 1971. Geology of Papatowai Subdivision. New Zealand Geological Survey Bulletin, 81:1-166.

Spicer, R.A., Ahlberg, A., Herman, A.B., Kelley, S.P., Raikevich, M.I., and Rees, P.M. 2002. Palaeoenvironment and ecology of the middle Cretaceous Grebenka flora of northeastern Asia. Palaeogeography, Palaeoclimatology, Palaeoecology, 184:65-105. https://doi.org/ 10.1016/s0031-0182(02)00247-x

Stevens, G.R. 1971. Relationship of isotopic temperatures and faunal realms to JurassicCretaceous Paleogeography, particularly of the south-west Pacific. Journal of the Royal Society of New Zealand, 1:145-158.

Stevens, G.R. 1980. Southwest Pacific faunal palaeobiogeography in Mesozoic and Cenozoic times: a review. Palaeogeography, Palaeoclimatology, Palaeoecology, 31:153-196.

Stevens, G.R. and Clayton, R.N. 1971. Oxygen isotope studies on Jurassic and Cretaceous belemnites from New Zealand and their biogeographic significance. New Zealand Journal of Geology and Geophysics, 14:829-879.

Stirling, J. 1900. Notes on the fossil flora of South Gippsland. Special Report on the Coalfields, Department of Mines, Victoria, 7:1-6.

Thomas, H.H. 1930. Further observations on the cuticle structure of Mesozoic cycadean fronds. Botanical Journal of the Linnean Society, 48:389-414. https://doi.org/10.1111/j.10958339.1930.tb02581.x

Thomas, H.H. and Bose, M.N. 1955. Pachydermophyllum papillosum gen. and sp. nov. from the Yorkshire Jurassic. Annals and Magazine of Natural History, 12:335-543. https://doi.org/ $10.1080 / 00222935508655663$

Thorn, V. 2001. Vegetation communities of a high paleolatitude Middle Jurassic forest in New Zealand. Palaeogeography, Palaeoclimatology, Palaeoecology, 168:273-289. https://doi.org/ 10.1016/s0031-0182(01)00203-6 
Tidwell, W.D. 1994. Ashicaulis, a new genus for some species of Millerocaulis (Osmundaceae). Sida, 16:253-261.

Tidwell, W.D., Britt, B.B., and Wright, W.W. 2013. Donponoxylon gen. nov., a new spermatophyte axis from the Middle to Late Jurassic of Australia and New Zealand. Review of Palaeobotany and Palynology, 196:36-50. https://doi.org/10.1016/j.revpalbo.2013.03.008

Tosolini, A.-M.P., McLoughlin, S., Wagstaff, B.E., Cantrill, D.J., and Gallagher, S.J. 2015. Cheirolepidiacean foliage and pollen from Cretaceous high-latitudes of southeastern Australia. Gondwana Research, 27:960-977. https://doi.org/10.1016/j.gr.2013.11.008

Townrow, J.A. 1967. On Rissikia and Mataia, podocarpaceous conifers from the lower Mesozoic of southern lands. Papers and Proceedings of the Royal Society of Tasmania, 101:103-136.

Turnbull, I.M. and Alibone, A.H. 2003. Geology of the Murihiku Area. Institute of Geological and Nuclear Sciences 1: 250,000 Geological Map 20.

Turner, S., Bean, L.B., Dettmann, M., McKellar, J., McLoughlin, S., and Thulborn, T. 2009. Australian Jurassic sedimentary and fossil successions: current work and future prospects for marine and non-marine correlation. GFF, 131:49-70. https://doi.org/10.1080/ 11035890902924877

Unger, F., 1864. Fossile Pflanzenreste aus Neu-Seeland. Paläontologie von Neu-Seeland, Novara-Expedition. Theil 1, Band 2:1-13.

Vera, E.I. and Passalia, M.G. 2012. Korallipteris, a new genus for Mesozoic Gleichenia-like fern fronds. Geobios, 45:421-428. https://doi.org/10.1016/j.geobios.2011.09.002

von Berchtold, F. and Presl, J.S. 1820. O Přirozenosti Rostlin. Krala Wiljma Endersa, Prague. von Sternberg, K.M. 1825. Versuch einer geognostischbotanischen Darstellung der Flora der Vorwelt, Vol. I. Ernst Brenck's Wittwe, Regensburg.

Wainman, C.C., Hannaford, C., Mantle D., and McCabe P.J. 2018. Utilizing U-Pb CA-TIMS dating to calibrate the Middle to Late Jurassic spore-pollen zonation of the Surat Basin, Australia to the geological time-scale. Alcheringa, 42:402-414. https://doi.org/10.1080/ 03115518.2018.1457179

Walkom, A.B. 1917. Mesozoic floras of Queensland, part 1, the flora of the Ipswich and Walloon Series, Filicales, etc. Queensland Geological Survey Publication, 257:I-66.

Walkom, A.B. 1919. On a collection of Jurassic plants from Bexhill, near Lismore, N.S.W. Proceedings of the Linnean Society of New South Wales, 44:180-190.

Walkom, A.B. 1921. Mesozoic floras of New South Wales. Part 1- Fossil plants from Cockabutta Mountain and Talbragar. Memoirs of the Geological Survey of New South Wales, Palaeontology, 12:1-21.

Walkom, A.B. 1928. Fossil plants from Plutoville, Cape York Peninsula. Proceedings of the Linnean Society of New South Wales, 53:145-150.

Walkom, A.B. 1944. Fossil plants from Gingin, W.A. Journal of the Royal Society of Western Australia, 28:201-207.

Watson, J. and Sincock, C.A. 1992. Bennettitales of the English Wealden. Monograph of the Palaeontological Society, 588:1-228.

Watters, W.A., Speden, I.G., and Wood, B.L. 1968. Sheet 26-Stewart Island. Geological map of New Zealand 1:250 000. Department of Scientific and Industrial Research, Wellington.

White, M.E. 1961. Report on 1960 collections of Mesozoic plant fossils from the Northern Territory. Bureau of Mineral Resources, Geology and Geophysics, Australia, Records, 1961/ 146:1-26.

White, M.E. 1981. Revision of the Talbragar Fish Bed Flora (Jurassic) of New South Wales. Records of the Australian Museum, 33:695-721. https://doi.org/10.3853/j.00671975.33.1981.269

White, M.E. 1986. The Greening of Gondwana. Reed Books, Frenchs Forrest, N.S.W.

Wood, B.L. 1956. The geology of the Gore Subdivision. New Zealand Geological Survey Bulletin, 53:1-127.

Wright, N., Zahirovic, S., Müller, R.D., and Seton, M. 2013. Towards community-driven, openaccess paleogeographic reconstructions: integrating open-access paleogeographic and paleobiology data with plate tectonics. Biogeosciences, 10:1529-1541. https://doi.org/ 10.5194/bg-10-1529-2013

Zhou, N., Wang, Y., Li, L., and Zhang, X.-Q. 2015. Diversity variation and tempo-spatial distributions of the Dipteridaceae ferns in the Mesozoic of China. Palaeoworld, 25:263-286. https://doi.org/10.1016/j.palwor.2015.11.008 